$$
\text { UNIVERSIDADE DE SÃO PAULO }
$$

FACULDADE DE FILOSOFIA, LETRAS E CIÊNCIAS HUMANAS

DEPARTAMENTO DE LETRAS CLÁSSICAS E VERNÁCULAS

PROGRAMA DE PÓS-GRADUAÇÃO EM FILOLOGIA E LÍNGUA PORTUGUESA

\title{
A CONJUGAÇÃO DE 'SER' E DE ‘TER' EM ALGUNS LIVROS DIDÁTICOS DE PORTUGUÊS LÍNGUA ESTRANGEIRA SOB A ÓTICA DO PENSAMENTO COMPLEXO.
}


UNIVERSIDADE DE SÃO PAULO

FACULDADE DE FILOSOFIA, LETRAS E CIÊNCIAS HUMANAS

DEPARTAMENTO DE LETRAS CLÁSSICAS E VERNÁCULAS

PROGRAMA DE PÓS-GRADUAÇÃO EM FILOLOGIA E LÍNGUA PORTUGUESA

\title{
A CONJUGAÇÃO DE 'SER' E DE 'TER' EM ALGUNS LIVROS DIDÁTICOS DE PORTUGUÊS LÍNGUA ESTRANGEIRA SOB A ÓTICA DO PENSAMENTO COMPLEXO.
}

Linei Matzenbacher Zampietro

\begin{abstract}
Dissertação de Mestrado apresentada à Área de Pós-Graduação em Filologia e Língua Portuguesa do Departamento de Letras Clássicas e Vernáculas da Faculdade de Filosofia, Letras e Ciências Humanas da Universidade de São Paulo, para a obtenção do título de Mestrado
\end{abstract}

Orientador: Prof. Dr. Reginaldo Pinto de Carvalho 


\section{AGRADECIMENTOS}

Ao meu orientador, Prof. Dr. Reginaldo Pinto de Carvalho

Profa. Dra. Neide T. Maia González - FFLCH, USP

Prof. Dr. Manoel Luiz Gonçalves Correa - FFLCH, USP

Profa. Dra. Rosane de Sá Amado - FFLCH, USP (participante das Bancas do Exame de Qualificação e de Defesa)

Profa. Dra. Lígia Fonseca Ferreira - FFLCH, USP (participante da Banca do Exame de Qualificação)

Profa. Dra. Regina Célia Pagliuchi da Silveira - PUC, SP (participante da Banca de Defesa)

Ao meu marido, Evanir, por seu apoio incondicional. 


\section{SUMÁRIO}

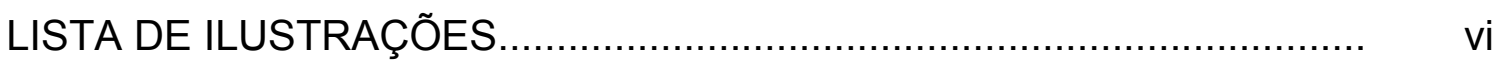

LISTA DE ABREVIATURAS E SIGLAS ............................................ vi

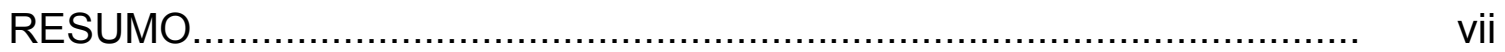

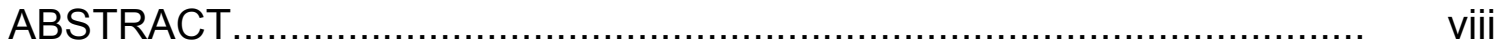

INTRODUÇÃ

1. O PENSAMENTO COMPLEXO_.................................................... 6

1.1. Definição........................................................................... 6

1.2. Como tudo começou....................................................................... 8

1.3. O que o pensamento complexo procura substituir .......................... 10

1.4. Os desafios que o pensamento complexo lança............................... 14

1.5. Características do pensamento complexo........................................ 14

1.6. Os princípios do pensamento complexo........................................... 16

2. DEFINIÇÃO DE LÍNGUA NA ÓTICA DO PENSAMENTO COMPLEXO E SUA 'EQUIVALÊNCIA' NO PARADIGMA FUNCIONAL ...................... 20

2.1. Definição de língua................................................................ 20

2.2. Os princípios do Paradigma Complexo e o Paradigma Funcional....... 24

2.2.1. Princípio Sistêmico ou Organizacional............................................. 24

2.2.2. Princípio Hologramático.............................................................. 25

2.2.3. Princípios da Retroatividade e da Recursividade.......................... $\quad 26$

2.2.4. Princípio da Autonomia/Dependência............................................. 27

2.2.5. Princípio Dialógico...................................................................... 28

2.2.6. Princípio da Dependência das Condições Iniciais........................... 28

3. AQUISIÇÃO DA LÍNGUA MATERNA E ESTRANGEIRA - COMO APRENDEMOS?

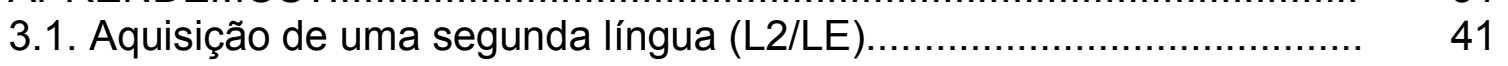

4. OS LIVROS DIDÁTICOS (LDS) DE PORTUGUÊS PARA ESTRANGEIROS COM ABORDAGEM COMUNICATIVA ...................... 51

4.1. A abordagem comunicativa.......................................................... 51

4.2. A questão dos materiais autênticos............................................. 55

4.3. O livro didático (LD) ............................................................. 57

4.4. O aluno jovem ou adulto...................................................... 60

5. METODOLOGIA - ALGUMAS PERGUNTAS QUE RESUMEM A BASE TEÓRICA VISTA ATÉ AQUI...... 
6. ANÁLISE DE CORPUS - VERBO 'SER'.............................................. 68

6.1. Introdução do verbo 'ser'........................................................... 68

6.2. O Pretérito Perfeito e o Imperfeito do Indicativo de 'ser' e de 'ter'........ 82

6.2.1. O Pretérito Perfeito do Indicativo..................................................... 83

6.2.2. O Pretérito Imperfeito do Indicativo................................................ 86

6.3. 'Ser' como auxiliar - a voz passiva .................................................. 95

7. ANÁLISE DO CORPUS - VERBO 'TER'.............................................. 102

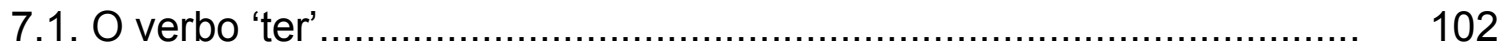

7.2. O 'ter' como auxiliar.................................................................. 105

7.2.1. Os tempos compostos do Indicativo............................................ 105

7.2.1.1. O Pretérito Perfeito Composto do Indicativo................................ 105

7.2.1.2. O Pretérito-mais-que-perfeito Composto do Indicativo................... 111

7.2.1.3. O Futuro do Presente e do Pretérito Compostos do Indicativo....... 114

7.2.2. Os tempos compostos do Subjuntivo.............................................. 115

8. INTRODUÇÃO DOS VERBOS 'SER' E 'TER' NA SÉRIE NEW INTERCHANGE ........................................................................ 120

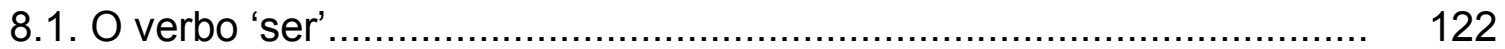

8.1.1. A voz passiva...................................................................... 123

8.2. O verbo 'ter' ...................................................................... 125

8.2..1 O verbo 'ter' como auxiliar dos tempos compostos.......................... 127

9. UMA ÚLTIMA PALAVRA SOBRE NOSSO CORPUS - A VISÃO DE ALUNO E DO RELACIONAMENTO ALUNO/PROFESSOR......................... 133

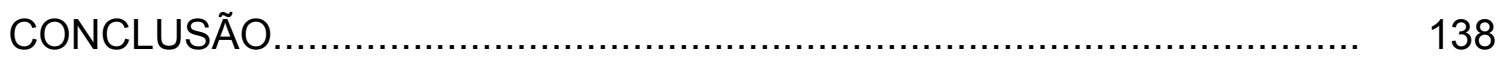

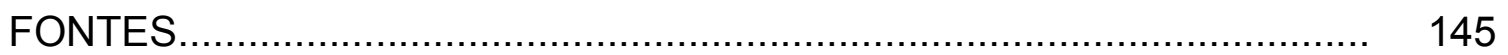

REFERÊNCIAS BIBLIOGRÁFICAS..................................................... 146 


\section{LISTA DE ILUSTRAÇÕES}

\section{Relação de Quadros}

Quadro Título

Pág.

$1 \quad$ As duas abordagens de Língua (NEVES, 1997)......................... 22

2 Diferenças entre os Paradigmas Formal e Funcional.................... 28

3 Diferença entre 'ser' e 'estar' no Falar...Ler...Escrever... .............. 72

4 Diferenças entre Perfeito e Imperfeito do Indicativo no Fala

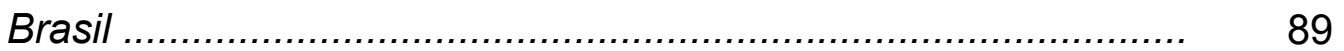

$5 \quad$ A voz passiva no Falar...Ler...Escrever... ................................ 96

$6 \quad$ Os tempos compostos no Bem-Vindo! ....................................... 110

7 Conjunções que exigem o Subjuntivo no Avenida Brasil 2.......... 118

\section{LISTA DE ABREVIATURAS E SIGLAS}

CELPE-Bras - Certificado de Proficiência em Língua Portuguesa

LD - Livro didático

PLE - Português Língua Estrangeira

LM - Língua materna

L2 - Segunda língua

LE - Língua estrangeira 


\section{RESUMO}

A partir de uma base teórica que cruza textos advindos do pensamento complexo (Filosofia), do paradigma funcional (Lingüística) e de autores diversos das áreas de Didática, Sociologia e Lingüística Aplicada, afinados de alguma maneira com o paradigma ou pensamento complexo, analisaremos a forma de como a conjugação verbal dos verbos 'ser' e 'ter' é introduzida em nosso corpus - quatro livros didáticos de português (do Brasil) para estrangeiros de grande circulação no sul e sudeste do País, e tentaremos obter por meio dessa análise uma visão do quanto cada obra de nosso corpus se aproxima de nossa base teórica.

Tal base, resumida em 'quesitos' no capítulo 5 a serem satisfeitos ou não pelo corpus analisado nos capítulos 6 e 7, encara o indivíduo/aprendiz como um ser extremamente complexo pois portador de nuances as mais diversas, que se não consideradas no processo de aquisição da linguagem, aquisição por si só também extremamente complexa, corremos o risco de se ver esse indivíduo frustrado em sua tentativa legítima de aprender o português como língua estrangeira.

A título de sugestão de melhorias na forma como nosso corpus introduz e sedimenta os verbos 'ser' e 'ter', descreveremos como os equivalentes desses verbos no inglês são introduzidos pela série New Interchange, além, e principalmente, de oferecer sugestões de melhorias inspiradas em nossa base teórica e em nossa experiência na área de ensino de Português Língua Estrangeira.

Palavras-chave: pensamento complexo; paradigma funcional; ensino/aprendizagem da conjugação verbal; livros didáticos de português língua estrangeira 


\section{ABSTRACT}

From a theory basis that crosses texts from the complex paradigm (Philosophy), the functional paradigm (Linguistics) and several other authors from Didactics, Sociology and Applied Linguistics, anyhow affined with the paradigms above, we will make an analysis of the way that the verb conjugation of 'ser' (to be) and 'ter' (to have) is presented by our corpus - four Portuguese as foreign language books largely sold in the South and Southeast of Brazil and try to visualize through this analysis in which degree each of these books gets close to our theory basis.

The result of this 'texts crossing' is summarized in quests form in chapter 5 to be met or not by our corpus analyzed in chapters 6 and 7 . Such theory basis considers the individual/learner as an extremely complex being, a carrier of many different aspects that, once not taken into account in the language acquisition process, such acquisition extremely complex itself, one takes the risk to have this individual frustrated in his legitimate try to learn Portuguese as a foreign language.

As an improvement suggestion on how verbal conjugation of 'ser' and 'ter' could be presented by the Portuguese as foreign language books focused in this dissertation, we will describe how the verb conjugation of 'be' and 'have' is presented by the New Interchange series, besides offering improvement suggestions inspired by our theory basis and by our own experience in the field of teaching Portuguese as foreign language.

Key-words: complex paradigm; functional paradigm; teaching/learning the verbal conjugation; Portuguese as foreign language books/materials 


\section{Introdução}

Acreditamos que uma das partes mais complexas de se ensinar Português Língua Estrangeira (PLE), especialmente para falantes de línguas como o inglês, o alemão e línguas orientais, tanto na abordagem comunicativa quanto nas mais tradicionais, é a conjugação verbal, seja por sua forma, seja por seu uso.

Além disso, já que o livro didático é feito, como o próprio nome diz, para ser didático, para facilitar a aprendizagem, acreditamos que uma abordagem exclusivamente lingüística não daria conta de analisar como a conjugação dos verbos 'ser' e 'ter', focos do presente trabalho, apresenta-se em nosso corpus.

Assim, iniciamos nossa pesquisa a partir da filosofia ou, mais especificamente, a partir de uma corrente de pensamento mais ou menos recente dentro da filosofia, que, só por sua denominação, já sugere o muito que podemos (re)pensar sobre como ensinar e como o aluno aprende uma nova língua: o pensamento complexo ou o paradigma complexo.

A partir de Morin \& Le Moigne (2000), Morin (s/d, 1997, 2002a e b, 2003), Britto (1997), Demo (2001) e Kartchner (s/d), descreveremos esse novo paradigma no capítulo um do presente trabalho, seus princípios, sua proposta, a fim de entendermos como o processo de ensino/aprendizagem acontece e de como poderia ser facilitado.

Pretendemos, ao ouvir autores de diferentes áreas, descobrir como cada disciplina pode colaborar para uma visão mais abrangente da tarefa de ensinar e de aprender uma língua estrangeira ao mesmo tempo em que considera o indivíduo e suas necessidades.

Por defender uma mudança de paradigma na abordagem da educação (pensamos que ensinar uma língua também é um tipo de educação, já que ensinamos/aprendemos a nos comunicar dentro daquela língua seguindo padrões comportamentais bem definidos, reeducando nosso aparelho fonador, aprendendo qual a melhor escolha para determinada situação, etc.), deslocando o enfoque em disciplinas como assuntos estanques para uma visão mais global do ser humano, acreditamos que o pensamento complexo possa contribuir bastante para compreender 
o processo de aprendizagem em geral e mais especificamente o da aprendizagem da conjugação dos verbos 'ser' e 'ter' do português do Brasil, e como o livro didático deveria apresentá-la de uma maneira mais clara e de fácil assimilação.

Dessa forma, tentamos, além de descrever, esclarecer os princípios do pensamento complexo, o que ele pretende mudar, suas características, como ele encara a sociedade, a língua e o indivíduo e o que tal pensamento pode trazer de contribuição para a elaboração de materiais didáticos mais abrangentes.

Além dessa maior abrangência, a escolha do Paradigma Complexo como base teórica para análise de nosso corpus traz em si um elemento de originalidade: nas dezenas de bancos de teses e instituições consultadas, incluindo os da USP, UNICAMP, UNESP, PUC, UFRGS, nenhum trabalho nessa linha foi encontrado.

Logo depois da descrição dos princípios do pensamento complexo (ou Paradigma Complexo), no capítulo dois, fazemos nossa entrada na Lingüística por meio de um de seus paradigmas, o funcional. A partir de Neves (1997 e 2004), tentaremos demonstrar o quanto o paradigma funcional aproxima-se do pensamento complexo e o complementa em sua visão de língua e de aprendizagem dessa língua.

Sentimos a necessidade de aproximar o paradigma funcional do paradigma complexo especialmente por causa do enfoque do presente trabalho: a conjugação verbal (de 'ser' e de 'ter', no caso), parte integrante do objeto de estudo da Lingüística: a própria língua.

Mais adiante, no capítulo três, questões importantes sobre como aprendemos e, principalmente, sobre como aprendemos uma nova língua, serão levantadas na tentativa de apontar o que há em comum a esse respeito entre os dois paradigmas citados (o complexo da filosofia e o funcional da lingüística) e textos de didática, sociologia e lingüística aplicada, e assim ouvir o que cada um desses campos distintos tem a dizer sobre o processo de aprendizagem e o papel do livro didático em tal processo.

Serão ouvidos autores como Germain (1996) (sobre como aprendemos uma segunda língua), Krashen (1982) (sobre a teoria do input compreensível), Menezes (s/d) (sobre o modelo fractal de aquisição), Moita Lopes (1996) (sobre a interlíngua) e Almeida Filho (2002) (sobre aprendizagem formal e subconsciente), além de Morin (2003) (aprendizagem como processo em espiral, como organização do conhecimento), 
Vygotsky (1991) (a zona proximal de desenvolvimento), Kuzendorff (1997) (sobre o papel de exercícios indutivos), Demo (2002) (sobre a aquisição do conhecimento no paradigma complexo), Santos (2003) (sobre o indivíduo complexo e seu envolvimento ativo na elaboração de conceitos; sobre a construção do conhecimento como provisória ou uma bricolagem) e Martins (s/d) (sobre as teorias de Vygotsky).

No capítulo quatro falaremos também sobre o livro didático de português para estrangeiros de abordagem comunicativa de ensino, abordagem essa que, como tentaremos demonstrar, é a que mais se aproxima das teorias trazidas à baila por este trabalho.

Traremos idéias de autores nos quais enxergamos alguma relação com o pensamento complexo, como Galloway (1993) e Puren (2004) (sobre o método comunicativo), Tan (2004) (sobre as limitações de tal método e sobre a abordagem temática), Almeida Filho (2002) (sobre a interdisciplina), Ferreira (1992) (sobre os níveis de linguagem), van Passel (1983) (sobre o aluno adulto) entre outros.

Além disso, buscaremos em diversos autores subsídios para melhor entender como um livro didático de língua estrangeira deveria apresentar-se para mais bem envolver seu público-alvo (entenda-se 'o aluno'), considerado a partir dos paradigmas complexo e funcional, ou seja, voltados a indivíduos com uma história, com razão e emoções, com senso estético, com toda uma cultura ${ }^{1}$ por trás, enfim, complexos pois diferentes em suas origens e similares em sua vontade de aprender o português e de se sentir um pouco parte de nossa cultura e de nossa sociedade.

Para isso, ouviremos também autores como Franzoni (1992) (sobre material autêntico e comunicação propositada) e Tomlinson (2001) (sobre o que os livros didáticos deveriam oferecer e exposição constante aos novos inputs em diferentes contextos).

No capítulo cinco, exporemos nossa metodologia para análise dos dados: a partir de 15 perguntas-quesito que resumem nossa base teórica, observaremos como 'ser' e 'ter' são introduzidos e sedimentados nas obras de nosso corpus ao mesmo tempo em que as sugestões de melhoria são inseridas.

\footnotetext{
${ }^{1}$ Neste trabalho, adotaremos a definição de 'cultura' do Moderno Dicionário da Língua Portuguesa, Michaelis, ou seja, "sistema de idéias, conhecimentos, técnicas e artefatos, de padrões de comportamento e atitudes que caracteriza uma determinada sociedade" (MICHAELIS, 1998, p. 623).
} 
Como corpus deste trabalho, elegemos quatro livros didáticos (doravante LD) de português para estrangeiros que de alguma forma se dizem 'comunicativos' ou voltados à comunicação, disponíveis em grandes livrarias em São Paulo, capital, de acordo com os seguintes critérios: 1. que possuam o mesmo público-alvo (alunos estrangeiros, jovens e adultos, de qualquer nacionalidade); 2. que cubram o nível básico do curso; 3 . que se proponham a ensinar a língua voltada à comunicação básica do dia-a-dia e não a campos específicos (como a área de negócios, por exemplo); 4. que, de acordo com nossa experiência, sejam adotados em escolas ou universidades no sul e no sudeste do País. ${ }^{2}$

Tais livros didáticos serão analisados em sua forma de apresentar e sedimentar a conjugação dos verbos 'ser' e 'ter': os capítulos seis e sete comentam como cada um desses verbos aparece no Falar...Ler...Escrever... de Lima \& lunes (1999, 2ª. ed.); no Avenida Brasil 1 e 2 de Lima et al (1991 e 1998, 2ª . ed.); no Fala Brasil de Coudry \& Fontão (1997, 10 . ed.), e no Bem-Vindo de Ponce et al (2003, 5a . ed.), doravante denominados somente por seus títulos neste trabalho.

Os objetivos da análise de nosso corpus serão: 1. Por meio da análise da introdução dos verbos 'ser' e 'ter', observar o quanto cada LD analisado possui em comum com nossa base teórica; 2. Comparar nosso corpus com um método comunicativo de ensino do Inglês para efeito de sugestões de melhorias; 3 . Além da descrição e análise da forma como 'ser' e 'ter' são introduzidos e sedimentados nesses LDs, elaborar sugestões de melhorias compatíveis com o Pensamento Complexo e de acordo com nossa experiência de oito anos no assunto ${ }^{3}$.

Além dos livros do aluno (livros-texto), levaremos também em consideração os manuais de exercícios que os acompanham sempre que sentirmos a necessidade de mais esclarecimentos sobre as formas empregadas na introdução e sedimentação do 'ser' e do 'ter'.

\footnotetext{
${ }^{2}$ Não serão incluídos LDs nem gramáticas de PLE feitos no exterior como Falar é Aprender: português para estrangeiros de Fernando José Rodrigues, e Gramática de português para estrangeiros de Lígia Arruda, ambos da Porto Editora, Portugal. Também não serão incluídas séries como a Teach yourself Portuguese da McGraw-Hill, nem a Ultimate Portuguese (series) da Living Language, entre outros.

${ }^{3}$ Consideraremos o ambiente endolíngüe de uso desses LDs, o seja, alunos estrangeiros aprendendo o Português aqui no Brasil, quando o professor e o LD não são as únicas fontes de aprendizado da língua (definição de FRANZONI, 1992). Isso não significa, porém, que as sugestões de melhorias oferecidas não possam ser utilizadas em aulas fora do País.
} 
O presente trabalho se justifica na medida em que o português é falado em diversos órgãos internacionais, além do Mercosul e da Comunidade Européia, com um total aproximado de mais de 210 milhões de falantes em 8 países ${ }^{4}$. Por outro lado, a quantidade de estrangeiros que desembarca em nosso País por motivo de trabalho, estudo ou como familiares de executivos, acadêmicos ou ainda para buscar uma vida melhor tem aumentado significativamente.

Prova disso é a grande procura pelo Celpe-Bras, exame de proficiência em português que acontece duas vezes por ano desde $1999^{5}$.

Dessa forma, decidimos descrever no capítulo oito, a título de mais sugestões de melhoria para nosso corpus, como uma série de projeção internacional, a New Interchange de Richards (2001, 2002, 2003 e 2004) de ensino de inglês, introduz o 'ser' e o 'ter' ('to be' e 'to have', respectivamente).

Optamos por essa série por ela adotar a abordagem comunicativa e ser difundida mundialmente (já vimos exemplares à venda em livrarias de diversos países da Europa e Ásia, além do Brasil) e, portanto, aparentemente uma metodologia de ensino de língua estrangeira bem aceita dentro e fora do País. Além disso, seu público-alvo coincide com o das obras de nosso corpus, ou seja, jovens e adultos de qualquer nacionalidade.

No capítulo nove, falaremos da visão de aluno e do relacionamento professor/aluno de acordo com informações dos manuais do professor de cada um dos LDs de nosso corpus, comparada à mesma visão no paradigma complexo.

Por fim, na conclusão, resumiremos nossa base teórica e comentaremos os resultados da análise de nosso corpus.

\footnotetext{
${ }^{4}$ Dados retirados do site do DEBP, Departamento de Educação Básica de Portugal: www.dgidc.minedu.pt//lingua portuguesa/linguaportugmundo.asp Consulta em 2 nov.2006.

${ }^{5} \mathrm{O}$ número de estrangeiros que presta o Celpe-Bras, Certificado de Proficiência da Língua Portuguesa para Estrangeiros, criado pelo governo federal em 1998, deu um grande salto de 141 inscritos em 1999 para 1.900 inscritos em 2005. Executivos, estudantes, trabalhadores de multinacionais e seus familiares compõem o público que almeja essa certificação (de acordo com a Revista Veja de $1^{\circ}$. Jun.2005 e o MEC, www.mec.gov.br . Consulta em 8 nov. 2006).
} 


\begin{abstract}
Embora a complexidade emerja inicialmente no campo das ciências naturais, não é menos verdadeiro afirmar que, se existe um âmbito ao qual corresponde por antonomásia o qualificativo 'complexo', esse é o mundo social e humano, que certamente é primordial para a experiência educativa (MORIN, 2003, p.51).
\end{abstract}

\title{
1. O Pensamento Complexo
}

\subsection{Definição}

\begin{abstract}
"O termo 'complexidade' tem sua etimologia do latim. Significa 'complectere', cuja raiz 'plectere' significa trançar, enlaçar; o prefixo 'com' acrescenta o sentido da dualidade de dois elementos opostos que se entrelaçam intimamente, mas sem anular a sua dualidade" (MORIN, 2003, p. 43).
\end{abstract}

Trata-se de um amálgama, um conjunto, uma rede de eventos, ações, interações, acasos que constituem o nosso mundo dos fenômenos. Gleick (1989) afirma que o complexo (ou o caos, como ele prefere) está por toda parte: no comportamento de um avião em vôo, no comportamento dos carros que se agrupam numa autoestrada, entre outros. Poderíamos até identificá-lo no 'comportamento' de uma determinada língua no passar do tempo (como bem nos mostra a Lingüística Histórica) - há padrões identificáveis, mas prever mudanças na língua é praticamente um exercício de futurologia, já que muitos aspectos têm de ser levados em consideração.

Morin (2003) afirma que o complexo recupera a incerteza, a incapacidade de se atingir a certeza, a incapacidade de formular uma lei que perdure para sempre e de conceber uma ordem que nunca termina. Por outro lado, recupera também algo sobre a lógica no que diz respeito à nossa incapacidade de evitar contradições - quando elas acontecem, a lógica deixa de ser operacional.

O complexo é o não reduzível, o não totalmente unificável, o não totalmente diversificável. É aquilo que é tecido simultaneamente (ordem/desordem; caos/padrão), um múltiplo, todo/partes, objeto/meio-ambiente, objeto/sujeito, claro/escuro. Se observarmos a natureza, a sociedade, a cultura, a língua, chegaremos à conclusão de que praticamente tudo o que nos rodeia é complexo, tanto superficial quanto profundamente - a complexidade não está somente nas interações, nos sistemas e organizações - segundo Morin \& Le Moigne (2000), ela é a base do mundo físico. 
E é exatamente por essa característica de não-redutibilidade que ela rompe as barreiras que separam as disciplinas científicas. É uma ciência da natureza global dos sistemas, por isso, como afirma Gleick (1989) reuniu pensadores de campos que estavam separados - a ciência caminhava para uma crise de especialização crescente, e essa tendência foi revertida por causa da ciência do caos, criada no campo da Física.

Derivada dessa ciência, a idéia de desordem ou aparente incoerência "tem um sentido mais rico, energético, de indistinção e de confusão entre poder criativo e poder destrutivo, e esse caos leva consigo a potencialidade genésica" (MORIN \& LE MOIGNE, 2000, p. 104) - dele nasce a organização, ou um equilíbrio temporário, já que forças contrárias porém complementares agem competitivamente o tempo todo.

Assim como a ciência do caos (GLEICK, 1989), o Pensamento Complexo compreende antes o processo do que o estado, o vir-a-ser do que o ser. Ele não nega a lógica, mas a utiliza como instrumento útil ao conhecimento e a descarta quando aparece a contradição, já que a lógica não dá conta desse aspecto da vida.

Como dizem Morin \& Le Moigne,

o pensamento complexo é, essencialmente o pensamento que trata com a incerteza e que é capaz de conceber a organização. É o pensamento capaz de reunir ('complexus': aquilo que é tecido conjuntamente), de contextualizar, de globalizar, mas, ao mesmo tempo, capaz de reconhecer o singular, o individual, o concreto (MORIN \& LE MOIGNE, 2000, p.207).

Para esses filósofos, é importante ensinar na escola de hoje os fundamentos da incerteza, uma das maiores conquistas da consciência, já que a aventura humana desde seu princípio sempre aconteceu em direção ao desconhecido.

Morin ainda aponta dois instrumentos para enfrentar o inesperado ou a impossibilidade de fórmulas fixas que apontem um caminho: a consciência do risco e da chance, e a estratégia, no sentido de ser capaz de modificar o comportamento em função das informações e dos conhecimentos novos que o desenvolvimento da ação nos propicia. Estratégia voltada para uma visão do todo, uma visão não fragmentada, mesmo que não seja possível compreender a realidade agora, já que a consciência é sempre posterior ao momento que se vive. 
Na verdade, o Pensamento Complexo é um novo paradigma ${ }^{6}$, cuja epistemologia ainda não está bem definida - o próprio paradigma reconhece que qualquer tentativa de definição epistemológica será sempre inacabada e deve constantemente ser trabalhada. Ele incorpora a simplificação desde que não mutilante, integra os modos simplificadores de pensar - mas não pode ser confundido com completude, já que reconhece a incompletude e a incerteza como princípios.

Mas qual seria a utilidade de uma epistemologia complexa então, já que ela não é capaz de trazer-nos nenhuma certeza? Em primeiro lugar, a de fazer-nos tomar consciência dos limites do conhecimento, o que é sempre um progresso do próprio conhecimento; em segundo, a de permitir-nos conhecer o nosso conhecimento e fazê-lo progredir em novos territórios ao confrontar-nos com a 'indizibilidade' do real.

O Pensamento Complexo identifica o que Morin (s/d) chama de 'as grandes doenças da era planetária':

- A grande doença do espírito: o idealismo que "esquece que as idéias são mediadores e tradutores; é a deificação das idéias em que a idéia se toma pelo real".

- A grande doença da razão: a racionalização "que encerra o real num sistema lógico coerente, coerente ao preço de terríveis mutilações".

- A grande doença da ideologia: o doutrinarismo, "que fecha o sistema de idéias ao diálogo com o real e com os outros sistemas de idéias." (MORIN, s/d, p. 32)

\subsection{Como tudo começou}

Segundo Gleick (1989) a ciência havia chegado a um ponto de especialização tamanha, que nenhuma das áreas de conhecimento se comunicava mais: a Física separou-se da Matemática, a Medicina ramificou-se absurdamente, etc. Há muitas vantagens nessa especialização excessiva - os resultados em termos de progresso

\footnotetext{
6 'Paradigma', na definição de Morin, "são estruturas de pensamento que de modo inconsciente comandam nosso discurso" (MORIN, 1997, p. 21). Um exemplo de paradigma seria o da disjunção que comandou a história do mundo e do pensamento ocidentais até o século XX: estudavam-se as partes sem relacioná-las ao todo, sem uma visão mais abrangente.
} 
tecnológico são gritantes, porém ela mutila a visão do todo e não permite a troca dos conhecimentos acumulados para a obtenção de resultados mais satisfatórios. Além disso, onde começa o caos, a ciência pára: geralmente outros assuntos 'válidos' são estudados e não o caos, caos no sentido de "lado irregular da natureza, o lado descontínuo e incerto" (GLEICK, 1989, p.3). Essas irregularidades eram classificadas como erro ou até monstruosidades pelos cientistas, que esqueciam o fato de o linear e o exatamente regular serem justamente as aberrações na natureza, pois raramente são nela encontrados.

O estudo do caos surgiu em uma 'área marginal' dentro da própria Física, cuja corrente principal vem sendo a física das partículas, que explora desde os blocos de construção da matéria a energias cada vez maiores, em escalas cada vez menores, em tempos cada vez mais curtos. Da física das partículas surgiram teorias sobre as forças fundamentais da natureza e sobre a origem do universo. Procurava-se responder a perguntas fundamentais, tais como: como começa a vida? O que é a turbulência? Em um universo governado pela entropia ${ }^{7}$, que leva inexoravelmente à desordem cada vez maior, como surge a ordem?

Isolar os mecanismos para depois somá-los (da tradição de examinar os sistemas localmente), não trazia a visão do todo, ou do longo prazo ou macroscópica essa tradição assim desmoronou, já que o comportamento global de um sistema pode diferir (e geralmente difere) do comportamento local (um exemplo seria a previsão do tempo, que raramente funciona a contento quando feita para grandes territórios sem considerar as condições específicas de cada lugar ou vice-versa).

Gleick (1989) afirma que os ecologistas do século XX, por exemplo, trataram as populações como sistemas dinâmicos, contribuindo muito dessa forma com a formulação da ciência do caos. Eles utilizavam modelos matemáticos para calcular as populações porém com a consciência de que os resultados "eram pálidas aproximações do fervilhante mundo real" (GLEICK, 1989, p. 56), já que uma população atinge o equilíbrio depois de subir, ultrapassar os limites e cair novamente. O uso de modelos matemáticos para calculá-las era sempre monitorado por seus 'donos' - caso os

\footnotetext{
${ }^{7}$ A definição de 'entropia' mais próxima ao conteúdo deste trabalho seria a da Wikipedia: "Grandeza termodinâmica geralmente associada ao grau de desordem. Ela mede a parte de energia que não pode ser transformada em trabalho".
} 
resultados diferissem muito do conhecimento que se tinha do comportamento real da população, "a ausência de alguma característica sempre podia explicar a discrepância: a distribuição de idades na população, algum aspecto do território ou da geografia, ou a complicação de ter de contar dois sexos" (GLEICK, 1989, p. 61).

A ordem e a desordem são dois aspectos aparentemente opostos, mas que integram a realidade da vida. Dessa forma, a ciência do caos reconhece a coexistência desses aspectos, além de outros como linear/não linear, partícula/onda, morte/vida. Gleick cita Stanislaw Ulim nesse aspecto: "Chamar o estudo do caos de "ciência não linear' era como chamar a zoologia de 'estudo dos animais não-elefantes'” (GLEICK, 1989, p. 64).

\subsection{O que o Pensamento Complexo procura substituir}

Edgar Morin foi quem levou a ciência do caos para a Filosofia, preferindo renomeá-la de Pensamento Complexo. Ele afirma que tal teoria surgiu por causa da crise do conhecimento científico, que acreditava assentar-se "sobre dois fundamentos seguros: a objetividade dos enunciados científicos, objetividade estabelecida pelas verificações empíricas, e a coerência lógica das teorias que se fundavam nestes dados objetivos" (MORIN, s/d, p. 14).

Demo (2002) fala em três pressupostos da tradição moderna de propensão positivista: $1^{\circ}$.) a realidade não se mostra à primeira vista; $2^{\circ}$.) ao fundo, podem-se descobrir esquemas mais simples de funcionamento da realidade ('seus átomos'); $3^{\circ}$.) ocorrendo convergência entre pensamento e realidade pensada, podem-se descobrir leis explicativas da realidade.

Era a época das teorias científicas que se pretendiam absolutamente certas. Ainda segundo Morin (s/d), Popper transformou o conceito de ciência, que deixou de ser sinônimo de certeza para transformar-se em sinônimo de incerteza. Em outras palavras, a ciência é um contínuo descobrir e redescobrir, pensar e repensar, um ir-evir, lembrando muito o movimento de uma espiral: voltamos aos princípios explorados anteriormente mas para repensá-los e até reformulá-los: 
Não há corte epistemológico radical. Não há uma ciência pura, não há um pensamento puro, não há uma lógica pura. A vida alimenta-se das impurezas, ou melhor, a realização e o desenvolvimento da ciência, da lógica, do pensamento têm necessidade destas impurezas (MORIN, s/d, p. 34).

No campo da Lingüística, Britto (1997) comenta que os gramáticos de Port-Royal baseavam-se na hipótese racionalista da linguagem, na qual subjaz a aposta de que para cada expressão lingüística se possa encontrar uma representação de mundo correspondente: "O ensino da gramática, tanto das formas corretas quanto das partes do discurso, se justificaria na medida exata em que uma forma correta corresponderia a um pensamento bem elaborado" (BRITTO, 1997, p. 168).

Britto cita Ludwig Wittgenstein, filósofo austríaco, que questiona a idéia de uma única linguagem redutível a uma única explicação lógica: "uma rede complicada de semelhanças, constituindo um mosaico - seria isso que caracteriza tudo o que chamamos 'linguagem'” (BRITTO, 1997, p.170). Assim, não é possível afirmar que a língua idealizada das gramáticas seja a única disponível para a comunicação - isso significaria um empobrecimento da visão de algo tão complexo quanto a linguagem. Kartchner (s/d) afima que

se propõe que a teoria do caos (entenda-se Pensamento Complexo) oferece aos lingüistas uma nova perspectiva de sua disciplina. Se aceitam que há comportamentos não lineares na linguagem, então talvez possam desenvolver uma forma de compreender um pouco melhor sua ciência e sua arte, e de revelar muitos dos segredos escondidos na linguagem (KARTCHNER, s/d, p.94).

O autor esclarece ainda a noção de linearidade: ela diz respeito a um sistema no qual qualquer mudança introduzida em estado inicial, resulta em uma mudança proporcional nos estados subseqüentes. Já os sistemas não lineares (caso da linguagem) não possuem tal característica: uma pequena perturbação no sistema (uma mudança fonética, por exemplo) pode ou não trazer resultados muito exagerados, sejam aumentados ou diminuídos.

Segundo Morin e Le Moigne (2000) a nossa incapacidade de reconhecer a complexidade, assim como tratá-la e pensá-la, é resultado do sistema educativo: "ele nos ensina que atrás da aparente complexidade dos fenômenos se escondem as leis simples da natureza, que são as estruturas anônimas que operam através da singularidade concreta dos seres humanos e da sociedade" (MORIN \& LE MOIGNE, 2000, p.90-91). O conceito-mestre do determinismo faz da incerteza o estado provisório 
da ignorância de uma Ordem escondida e não uma das características da nossa relação com o universo. Também justifica a aplicação da sua lógica mecânica aos problemas vivos, humanos e sociais. Pela fragmentação, elimina o contexto e sua singularidade, sua localidade, sua temporalidade.

A inteligência cega ou parcelada, provocada pelo excesso de especialização sem a visão do todo, "destrói na origem as possibilidades de compreensão e de reflexão, eliminando também todas as chances de um julgamento correto ou de uma visão a longo prazo" (MORIN \& LE MOIGNE, 2000, p. 94). Ou ainda, como afirma Neves,

(...) sabemos que, em ciência, uma simplificação a qualquer custo pode significar barateamento, mistificação, falsidade, e não é com a linguagem nossa de cada dia que vamos ter o direito de fazer isso, fingindo que ela está mumificada e que é assim que dela nos servimos (NEVES, 2004, p. 126).

Como mencionado, há vantagens reconhecidas na especialização, mas sem a visão do todo, ela acaba mutilando a realidade, subjugando e escravizando sob juízos de valor geralmente falsos e incoerentes.

A certeza desse modo de pensamento (da inteligência cega ou parcelada) viria, ainda segundo Morin \& Le Moigne (2000) dos quatro pilares da certeza - bases da ciência clássica até o início do século $X X: 1)$ o princípio da ordem (dela vem a concepção determinista e mecânica do mundo); 2) o princípio de separação (pertinente, porém levou à hiper-especialização); 3) o princípio da redução (reduz o conhecível àquilo que é quantificável, formalizável, segundo o axioma de Galileu: "os fenômenos só devem ser descritos com a ajuda de quantidades mensuráveis" (MORIN \& LE MOIGNE, 2000, p.96)); 4) o caráter absoluto da lógica dedutivo-identitária, cuja soberana absoluta é a racionalidade (tudo precisa ter uma explicação lógica, pondo fora dela (da lógica) aquilo que opera a invenção e a criação: “...essa lógica armou a concepção de um mundo coerente, inteiramente acessível ao pensamento, e tudo aquilo que excedia essa coerência se tornava não somente fora da lógica, mas também fora do mundo e fora da realidade" (MORIN \& LE MOIGNE, 2000, p. 98)).

A conjunção desses quatro pilares da certeza determinaria o pensamento simplificador, submisso à hegemonia da disjunção, da redução, do cálculo, cuja inteligência dele oriunda é de uma terrível eficácia, já que permitiu e desenvolveu a 
manipulação de inúmeras vitórias técnicas, "ignorando contudo os efeitos perversos que elas podem engendrar" (MORIN \& LE MOIGNE, 2000, p. 101).

O pensamento simplificador está estreitamente correlacionado à manipulação e conduz à dominação e ao desprezo, já que toma abstração por realidade e despreza tudo aquilo que não participa do projeto de dominação. Constituiu-se desse pensamento o "paradigma da disjunção/rejeição", e é justamente esse paradigma que o Pensamento Complexo procura não simplesmente substituir, mas incluir num todo maior e mais condizente com a realidade: "Há o desmoronamento epistemológico do atomismo, do elementarismo, do positivismo lógico ou não, da antiga certeza absoluta. 'Único ponto pouco próximo do certo nesse naufrágio: o ponto de interrogação', diz o poeta Salah Stetié" (MORIN \& LE MOIGNE, 2000, p. 131).

"O pensamento complexo coloca entre parênteses o cartesianismo e, simultaneamente, retoma e assume plenamente a idéia socrática de ignorância, a dúvida de Montaigne e a aposta pascalina" (MORIN, 2003, p. 55). Ou seja, a máxima cartesiana 'penso, logo existo' é posta a serviço de um ser humano mais completo, não somente racional, mas emocional e intuitivo, consciente dos limites de seu conhecimento e capaz de formular estratégias para expandi-lo. Ele põe em dúvida teorias que se dizem inquestionáveis e procura conhecer o todo para conhecer as partes e as partes para conhecer o todo, contextualizando e assim validando o seu conhecimento.

O pensamento complexo ressalta e corrige a cegueira de um pensamento simplificador que pretende tornar transparente o vínculo entre pensamento, linguagem e realidade, no sentido de detectar e evitar a atitude manipuladora de tomar o abstrato (o pensamento e seu instrumento, a linguagem) pela realidade, já que, ainda segundo Morin, "o conhecimento é uma tradução seguida de uma reconstrução. A percepção é uma tradução, as próprias palavras são traduções de traduções de reconstruções" (MORIN, 2003, p. 81). 


\subsection{Os desafios que o pensamento complexo lança}

Como Morin \& Le Moigne afirmam, "a complexidade é desafio e não solução" (MORIN \& LE MOIGNE, 2000, p. 134), já que ele lança pelo menos três desafios:

1) como reunir (o parcial ao global e ligar o global ao parcial, o um ao múltiplo, o universal ao singular, a autonomia à dependência; a ordem, a desordem e a organização reconhecendo inteiramente seus antagonismos; o separado e o inseparável; aquilo que é antagônico desde que apareça como complementar; a lógica e aquilo que a ultrapassa; a observação ao observador; etc.);

2) como tratar as incertezas;

3) como aceitar e reunir os antagonismos ou as contradições lógicas. Para os autores, o problema não é a quantidade de conhecimento para resolver esses desafios, mas a forma como se organiza esse conhecimento; não é somente abrir as fronteiras entre as disciplinas, mas principalmente transformar aquilo que gera essas fronteiras.

Além desses desafios, há ainda o desafio do método, diferente de metodologia ou programa, pois exige um sujeito capaz de utilizar estratégias. Um método que ultrapasse as alternativas provenientes da grande disjunção que ainda se faz entre espírito / matéria, dependência / autonomia, determinismo / liberdade, homem/natureza/cosmos, e que siga a demanda de Heráclito: "Juntem aquilo que concorda e aquilo que discorda, aquilo que está em harmonia e aquilo que está em desacordo" (MORIN \& LE MOIGNE, 2000, p.136).

\subsection{Características do Pensamento Complexo}

Morin \& Le Moigne falam em sistemas dinâmicos ou conjuntos de partes diversas, lineares e não lineares, que constituem um todo organizado: “(...) a organização em sistema produz qualidades ou propriedades desconhecidas das partes concebidas isoladamente: as emergências" (MORIN \& LE MOIGNE, 2000, p. 108). Dessa forma, as propriedades de um ser vivo não podem ser conhecidas na escala de seus constituintes moleculares isolados - elas 'emergem' pela e através da organização do sistema e retroagem sobre as moléculas dessa mesma organização. 
As outras principais características do Pensamento Complexo são as seguintes:

1) o estatuto semântico e epistemológico do termo 'complexidade' não se concretizou ainda. Segundo Demo (2002), a complexidade é reconstrutiva (reutiliza os mesmos elementos mas de forma diferente) e irreversível (não se pode passar do depois para o antes) - o ponto de partida produz algo para além de si mesmo (como a diversidade das espécies, por exemplo). A complexidade é autônoma e produz sua autonomia na incompletude, "porque, a rigor, só realidades incompletas podem ser autônomas" (DEMO, 2002, p.22), pois só se pode ser autônomo com referência aos outros, nunca sozinho;

2) é diferente de 'complicação' - o complicado, emaranhado ou multidependente pode reduzir-se a um princípio simples, já que não ultrapassa o uso linear da informação. Demo dá o exemplo do avião como algo complicado porém não complexo, uma vez que a máquina não trabalha para si mesma, não se auto-gere como fazem os seres vivos - "em totalidades complexas, a decomposição das partes destrói o todo, de tal sorte que é impraticável, a partir das partes, refazer o mesmo todo" (DEMO, 2002, p. 16); diz respeito à ciência, à sociedade, à ética, à política - é um problema de pensamento e de paradigma que envolve uma epistemologia geral; sabe que a certeza generalizada é um mito;

3) no pensamento complexo não existe nenhum fundamento certo para o conhecimento - ele é rotativo, funciona em espiral, num ir e vir do todo para a parte, da parte para o todo, do objeto para o sujeito, do sujeito para o objeto, sempre disposto à reformulação. Como diz Morin, "não há causa última, não há última análise, não há verdade adequada nem explicação primeira" (MORIN, 2003, p. 53-nota);

4) nunca é um pensamento completo, já que é um pensamento articulante, multidimensional e dialógico (unidade de contrários) pelo princípio de retroação ${ }^{8}$. O caminho para o conhecimento é para o pensamento complexo algo que nunca termina, já que é processo e progride a partir do momento em que reconhecemos o limite do próprio conhecimento;

\footnotetext{
${ }^{8}$ Este princípio, o de retroação, é explicado no subitem "Princípios do Pensamento Complexo" a seguir.
} 
5) ele sabe que existem dois tipos de ignorância: "a daquele que não sabe e quer aprender, e a ignorância (mais perigosa) daquele que acredita que o conhecimento é um processo linear, cumulativo, que avança trazendo a luz ali onde antes havia escuridão, ignorando que toda luz também produz sombras como efeito" (MORIN, 2003, p.55);

6) ele não despreza o simples, mas critica a simplificação pura, já que a complexidade é a união da simplificação e da complexidade - a redução ou simplificação muitas vezes são necessárias, mas é um erro achar que explicam tudo:

O que é verdadeiramente perturbador para o reino determinista e para os cultuadores incondicionais da fossilização da linguagem (no sentido de formalização/idealização da linguagem, excluindo a variação), é que a complexidade de um objeto qualquer remete a uma região do devir não redutível a nenhuma lógica, qualquer que seja ela (MORIN, 2003, p. 48).

O Pensamento Complexo pensa por meio de macroconceitos, pela associação de conceitos atômicos até então separados, por vezes antagônicos, mas que, em sua inter-relação, geram figuras complexas que, sem essa dinâmica, se reduzem a vapor, deixam de existir: “(...) um mundo totalmente determinista seria tão absurdo quanto um mundo no qual só existisse o acaso" (MORIN, 2003, p. 59). Dessa forma, as idéias de ordem e desordem tornam-se complementares, ou seja, onde há ordem aparente muitas vezes subjaz a desordem, e da desordem surge espontaneamente a ordem.

\subsection{Os Princípios do Pensamento Complexo}

Os princípios são o que Morin (2003) chama de "guia do método para um pensar complexo". Cabe-nos, então, antes de expor tais princípios, tentar esclarecer o que o autor chama de 'método'. São várias as suas características, mas a primeira e mais importante é a diferença de método e metodologia ou programa (pré-determinado em suas ações) - o método até pode seguir metodologias enquanto elas dão conta de 
encontrar e percorrer o caminho para o conhecimento, mas são por ele deixadas de lado quando isso não mais acontece.

O método é o que ensina a aprender - a viagem inicia-se com a busca do método que é em si o próprio caminho do conhecimento. Ele é um exercício de resistência espiritual "contra a cegueira e a rigidez geradas pelas convenções e clichês cunhados pela organização social” (MORIN, 2003, citando ADORNO, p. 30), como a racionalidade, a idealização e a normalização.

O método é estratégia (pré-determinada em suas finalidades) do sujeito e ferramenta geradora de suas próprias estratégias, e ajuda-nos a conhecer além de ser também conhecimento, já que vem sempre depois da experiência. Ele exige pleno emprego das faculdades do sujeito e possibilita a integração da contradição num conjunto sem perder sua potencialidade destrutiva e construtiva.

O método e a teoria são os dois componentes indispensáveis do conhecimento complexo: a teoria não é conhecimento, mas permite o conhecimento, e não é nada sem o método; o método regenera a teoria, deve construir-se no caminhar, é obra de um ser inteligente que ensaia estratégias para responder às incertezas, serve para aprender e ao mesmo tempo é aprendizagem, método como caminho e como estratégia, ele aprende porque seus resultados retroagem: “(...) o método define-se pela possibilidade de encontrar nos detalhes da vida concreta e individual, fraturada e dissolvida no mundo, a totalidade de seu significado aberto e fugaz" (MORIN, 2003, p. 23). O método como caminho se dissolve no caminhar, mas não é improvisação - se existe um, só poderá nascer durante a pesquisa.

Eis então os princípios que guiam o método para um pensar complexo:

1) Princípio Sistêmico ou Organizacional - religa o conhecimento das partes com o conhecimento do todo e vice-versa. O todo é sempre mais e menos que a soma das partes, já que algumas das qualidades das partes podem ser inibidas ou amplificadas pelo efeito do todo sobre elas.

2) Princípio Hologramático - cada parte contém praticamente a totalidade da informação do objeto representado - é o que Morin (1997) chama de 'operador hologramático', no qual cada célula contém o nosso patrimônio genético. Sua máxima é 'a parte está no todo, e o todo está na parte': a sociedade e a cultura estão presentes enquanto 'todo' no conhecimento e nos 
espíritos cognoscitivos. As partes podem ser eventualmente capazes de regenerar o todo e podem ser dotadas de autonomia relativa, podem estabelecer comunicações entre elas e realizar trocas organizadoras.

3) Princípio de Retroatividade (ou do círculo retroativo) - com este conceito, rompemos com a causalidade linear, já que o efeito retroage informacionalmente sobre a causa, permitindo a autonomia organizacional do sistema (a autonomia térmica de um ser vivo em relação ao mundo exterior, por exemplo, quando a geração de mais calor (efeito) retroage sobre a perda deste calor para o ambiente (causa)).

4) Princípio da Recursividade (ou do círculo recursivo) - vai além da retroatividade, pois traz dinâmica autoprodutiva e auto-organizacional (seus produtos são necessários para a própria produção do processo, os estados finais são necessários para a geração dos estados iniciais), desde que alimentada por um fluxo exterior: como Morin \& Le Moigne afirmam, "os indivíduos humanos produzem a sociedade em e pelas interações sociais, mas a sociedade, enquanto emergente, produz a humanidade desses indivíduos, trazendo-lhes a linguagem e a cultura" (MORIN \& LE MOIGNE, 2000, p. 210).

5) Princípio da Autonomia/Dependência (ou princípio da auto-ecoorganização): "Nossa autonomia como indivíduos não só depende da energia que captamos biologicamente do ecossistema, mas da informação cultural" (MORIN, 2003, p. 36).

6) Princípio Dialógico - associação complexa de instâncias aparentemente opostas, porém conjuntamente necessárias à existência, ao funcionamento e ao desenvolvimento de um fenômeno organizado. Esse princípio ajuda a pensar lógicas que se contrariam e se complementam em um sistema dinâmico sem excluírem ou anularem umas às outras (ordem/desordem/organização; indivíduo/totalidade social; vida/morte segundo a máxima de Heráclito: 'viver da morte, morrer da vida', trazendo a idéia de regeneração permanete a partir da morte das próprias células; etc.).

7) Princípio de Reintrodução do Sujeito cognoscente em todo o $\begin{array}{llllll}\text { conhecimento } & - & \text { reintroduz } & 0 & \text { papel do sujeito }\end{array}$ observador/computador/conceituador/estrategista, e reconhece que: a 
experiência não é uma fonte clara e inequívoca do pensamento; o conhecimento não é o acúmulo de informação, mas sua organização.

8) Princípio de Dependência das condições iniciais - permitimonos acrescentar esse princípio apontado por Gleick (1989), aos levantados por Morin (acima), já que, segundo Gleick, não se trata de um conceito novo, mas que faz parte da cultura: "Sabe-se muito bem, tanto na ciência como na vida, que uma cadeia de acontecimentos pode ter um ponto de crise que aumente pequenas mudanças. Mas o caos significava que tais pontos estavam por toda a parte" (GLEICK, 1989, p. 20). Gleick descreve aqui o efeito borboleta dependendo das condições meteorológicas na Amazônia, o bater das asas de uma simples borboleta poderia (ou não) provocar tempestades na Califórnia. Talvez esse conceito pudesse contribuir com os estudos sobre gramaticalização apontados por Neves (1997), Hopper \& Traugott (1993), entre outros.

Esses são alguns dos princípios que guiam as marchas cognitivas do pensamento complexo. Marcha ou caminhada que consiste em fazer um ir e vir incessante entre as certezas e as incertezas, entre o elementar e o global, entre o separável e o inseparável. Nunca estamos certos se nossas boas intenções vão gerar boas ações.

É por isso que a resposta a essa incerteza se encontra ao mesmo tempo na aposta e na estratégia. $\mathrm{Na}$ aposta, pois não temos absolutamente certeza de conseguir os resultados que queremos; na estratégia, que permite corrigir nossa ação, se vemos que ela deriva e vai para outro caminho (MORIN, 1997, p.23). 


\title{
2. Definição de Língua na ótica do Pensamento Complexo e sua 'equivalência' no Paradigma Funcional
}

\author{
(...) A linguagem faz o homem que fez a \\ linguagem; do mesmo modo, a linguagem fez a \\ cultura que produziu a linguagem. (MORIN, 1996, \\ p.114)
}

Usar a linguagem não constitui um fato puramente lingüístico, mas cada instância de comunicação é, em primeiro lugar, um evento humano e, a partir daí, social e cultural (NEVES, 2004, p. 37)

\subsection{Definição de Língua}

Morin define a linguagem como um todo que não é tudo -

polivalente e polifuncional, a linguagem humana exprime, constata, transmite, argumenta, dissimula, proclama, prescreve (...). Está presente em todas as operações cognitivas, comunicativas, práticas. É necessária à conservação, transmissão, inovação culturais. Consubstancial à organização de toda sociedade, participa necessariamente da constituição da vida na noosfera ${ }^{9}$. (MORIN, 2002a, p. 197).

Morin afirma que a língua (ou linguagem) é uma máquina auto-sócioorganizadora dentro da máquina sócio-cultural, no sentido de a língua ser um sistema autônomo mas ao mesmo tempo dependente como todo sistema complexo. O autor divide a língua em três níveis, sendo o primeiro nível onde ficam os fonemas, que, sem sentido, constituem enunciados com sentido que obedecem, "em cada língua, as regras gramaticais, sintaxe, vocabulário, e as próprias regras obedecem a determinações e 'estruturas' profundas, ainda misteriosas e controvertidas” (MORIN, 2002a, p.199).

No segundo nível, a língua funciona associada com as 'maquinarias' lógica e analógica, dependentes estas das regras fundamentais da computação/cogitação próprias da maquinaria cerebral humana: "Lógica e Lingüística são duas máquinas em uma, íntima e profundamente integradas uma na outra, mas irredutíveis uma à outra" (MORIN, 2002a, p.200).

\footnotetext{
9 'Noosfera' significa 'esfera' ou 'vida' das idéias, do espírito.
} 
Já o terceiro nível coloca em atividade os paradigmas, categorias, esquemas, modelos de pensar - a máquina cultural:

(...) compreendemos que a linguagem liga e ativa a totalidade multiforme e plural do universo antropossocial (...). Para falar em termos marxistas, a linguagem é parte organizadora da infra-estrutura, ao mesmo tempo que é parte organizadora da superestrutura social (MORIN, 2002a, p. 200).

Mais adiante em seu raciocínio, Morin chega a afirmar que a linguagem não é somente uma máquina, mas muito mais que isso, pois é dotada de vida própria em todos os níveis: as palavras e as nuanças nascem, degradam-se, morrem; palavras migram de uma língua para a outra; ela pode se transformar no decorrer de um ou dois séculos, pois tem vida muito intensa nas esferas marginais da gíria e da poesia, "onde a analogia desenvolve-se em liberdade" (MORIN, 2002a, p. 201).

Morin fala em universais lingüísticos, princípios, estruturas e regras que seriam obedecidas por todas as línguas existentes ou mortas, já que elas são somente variantes daqueles universais. Além disso, a língua possui dupla articulação, princípio hierárquico e lógico que permite um número infinito de combinações e enunciados. Nesse ponto, Morin aproxima a língua da noção de ser vivo, já que a dupla articulação é uma propriedade comum a todas as organizações biológicas, ou seja, comporta unidades discretas sem sentido operatório (moléculas para os seres vivos) que se associam para formar uma palavra, uma frase, um texto (tecidos, órgãos, um organismo).

Morin define a organização lingüística como 'auto-geno-feno-sócio-egoreorganização', ou seja: 'auto', que significa relativa autonomia da língua quanto aos seus dois tipos de ecossistema, a esfera sócio-cultural e o sujeito emissor; complexo 'geno-feno' que significa língua-fala (langue-parole de Saussure, paradigma-sintagma de Jackobson, competência-performance de Chomsky); 'sócio', que significa considerar a sociedade que produz a língua e que é produzida pela língua, quando esta operacionaliza as interações sociais; 'ego', que significa o sujeito emissor; o radical 're' que remete ao estado de reorganização/regeneração de todo ser vivo, já que "a linguagem está em evolução permanente porque se regenera em permanência" (MORIN, 2002a, p. 204) como a própria Lingüística Histórica bem atesta. 
Neves (1997) separa, na Lingüística, a visão de linguagem em dois grandes paradigmas: o formal e o funcional. O paradigma formal examina a linguagem como um objeto autônomo e investiga a estrutura lingüística independente do uso. Seus maiores representantes seriam Chomsky (Gerativismo) e, do estruturalismo americano, Bloomsfield, Trager, Bloch, Harris e Fries.

Já o paradigma funcional examina a linguagem como entidade não suficiente em si, totalmente dependente das interações sociais (as quais ela operacionaliza). Os maiores representantes desse paradigma seriam Halliday, Dik, a Escola de Praga, Firth, Lamb, a Escola de Londres e Saussure, implicitamente.

Em princípio, para o paradigma funcional, a linguagem não pode ser considerada autônoma, mas acreditamos que a teoria do Pensamento Complexo, com seu princípio dialógico, poderia contribuir para uma visão da linguagem que liga os dois paradigmas, formal e funcional, como opostos complementares.

O próprio Dik (1978 apud NEVES, 1997), com sua teoria de componentes integrados, deixa claro que a língua pode sim ser vista como autônoma, apesar de dependente do meio. Leech (1983 apud NEVES, 1997) corrobora essa visão criticando a adoção de uma hipótese em detrimento da outra (formalista ou funcionalista): “(...) seria tolo negar que a linguagem é um fenômeno psicológico como negar que ela é um fenômeno social" (NEVES, 1997, p.49). Ele liga as diferenças entre as duas abordagens, basicamente, a diferentes modos de ver a natureza da linguagem:

\begin{tabular}{|l|l|}
\hline \multicolumn{2}{|c|}{ Quadro 1 duas abordagens de Língua (NEVES, 1997) } \\
\hline \multicolumn{1}{|c|}{ Formalistas (Chomsky) } & \multicolumn{1}{c|}{ Funcionalistas } \\
\hline - língua como fenômeno mental & - língua como fenômeno propriamente social \\
\hline $\begin{array}{l}\text { - universais lingüísticos: herança lingüística } \\
\text { genética comum da espécie humana }\end{array}$ & $\begin{array}{l}\text { universais lingüísticos: derivação da } \\
\text { universalidade dos usos da linguagem nas } \\
\text { sociedades humanas }\end{array}$ \\
\hline $\begin{array}{l}\text { - aquisição da linguagem pela criança: } \\
\text { capacidade inata para aprender a língua }\end{array}$ & $\begin{array}{l}\text { aquisição da linguagem pela criança: } \\
\text { desenvolvimento das necessidades e } \\
\text { habilidades comunicativas da criança }\end{array}$ \\
\hline $\begin{array}{l}\text { - estudam a língua como um sistema } \\
\text { autônomo }\end{array}$ & $\begin{array}{l}\text { - a estudam em relação com sua função } \\
\text { social }\end{array}$ \\
\hline
\end{tabular}

Para fechar a idéia de que os dois paradigmas na verdade se complementam, Neves ainda cita Nascimento: "a comparação não tem sentido, pelo simples fato que formalismo e funcionalismo têm diferentes formas de estudo do mesmo objeto, daí 
diferentes pressupostos, objetivos e metodologia" (NEVES, 1997, p.50); Dillinger: "um estudo não exclui o outro, sendo ambos complementares e igualmente necessários" (NEVES, 1997, p. 53) e Halliday: "tanto a abordagem formalista quanto a funcionalista ligam-se à própria natureza da linguagem, além de se ligarem pela raiz ao pensamento ocidental" (NEVES, 1997, p.53).

$\mathrm{Na}$ verdade, Morin não desenvolve muito o conceito de linguagem ao se utilizar da Lingüística (que, segundo ele, é uma ciência-chave, mas não uma ciência rainha), pois cita somente alguns teóricos lingüistas cronologicamente até Chomsky. Pensamos que o Paradigma Funcional vem (incluída aí a Sociolingüística), então, complementar a visão de língua/linguagem como sistema complexo ou, como afirma llari, "uma imbricação de diferentes sistemas" (ILARI, 2001, p.19).

Nossa opção pelo Paradigma Funcional como porta de entrada pela Lingüística para a análise da conjugação verbal de livros didáticos de português para estrangeiros, fundamenta-se pelas inúmeras coincidências ou afinidades de que esse paradigma tem com o Pensamento Complexo. Neves (2004) descreve a natureza da linguagem (e da gramática) como um sistema

sempre ativado para a produção de sentidos, o que se opera nesse jogo entre restrições e escolhas que equilibra o sistema. Para responder a essa necessidade de equilíbrio, a língua é dinâmica e variável, é um sistema adaptável, sempre em acomodação, de tal modo que só na sua face sóciocultural se poderá admitir a existência de moldes e modelos (NEVES, 2004, p.85).

Vemos nessa descrição de língua diversas características dos sistemas complexos: dinamicidade, busca de equilíbrio (mesmo que provisório, já que está sempre em acomodação), variabilidade, adaptabilidade ao seu meio (social) e uma certa autonomia de regras para alcançar o equilíbrio. Nesse trecho, Neves na verdade discorre sobre a concepção de gramática como sistema de princípios que organiza os enunciados, usados naturalmente pelos falantes nativos de cada língua em situações de interação comunicativa. A opção pelas regras gramaticais de uma só variante (a língua padrão ou 'culta', por exemplo) é sempre determinada no nível sócio-cultural, ou seja, a variante valorizada por determinado grupo será a escolha natural para determinadas situações de uso. 


\subsection{Os princípios do Pensamento Complexo e o Paradigma Funcional}

Examinemos, então, os pontos em que o Paradigma Funcional da língua (que a define como instrumento de comunicação e tratamento funcional da sua própria organização) corresponde aos princípios do Pensamento Complexo:

2.2.1. Princípio Sistêmico ou Organizacional - para efeito de recordação, esse princípio fala da estreita ligação entre parte e todo, todo e parte, já que o todo é sempre mais e menos que a soma das partes. O Paradigma Funcional defende a contextualização ou a análise de termos (as palavras são polissêmicas) ou frases dentro de um contexto maior (o texto) para se chegar ao correto sentido desses termos.

Segundo Hoffmann (1989, apud NEVES, 1997), o paradigma funcional analisa a relação sistemática entre as formas e as funções em uma língua, afirmação essa corroborada por Halliday (1973, apud NEVES, 1997) quando afirma que o Paradigma Funcional interpreta a língua como uma rede de relações - as estruturas seriam interpretações dessas relações.

Há ainda abordagem funcionalista no modelo de Praga (Hjemslev), que, segundo Neves, é caracterizada como um estruturalismo funcional - sua visão funcional está na definição de língua, vista como um 'sistema de meios apropriados a um fim', e um 'sistema de sistemas', já que a cada função corresponde um subsistema.

Todos os subsistemas diriam respeito à frase: "A frase é reconhecida como uma unidade susceptível de análise não apenas nos níveis fonológico, morfológico e sintático, mas também no nível comunicativo" (NEVES, 1997, p.18), e sua organização é feita em tema (estático, de referência já estabelecida) e rema (dinâmico, de maior informatividade).

Neves explica que Dik filia a Gramática Funcional à Escola de Praga,

que concebe a língua como um sistema no qual se distinguem elementos nucleares e elementos periféricos e que, portanto, concebe as regras e os princípios da gramática mais como tendências do que como regras absolutas com condições 'sim/não' de aplicação (NEVES, 1997, p.146). 
Neves cita também Du Bois, que "propõe que as gramáticas sejam tratadas como sistemas adaptáveis, isto é, como sistemas parcialmente autônomos (por isso, sistemas) e parcialmente sensíveis a pressões externas (por isso, adaptáveis)" (NEVES, 2004, p.109). Neves esclarece, ainda, que para se admitir a língua como sistema, é necessário admitir-se que ela tem uma continuidade de existência. $A$ autora cita Halliday e sua teoria de que a língua é um sistema semântico:

Quando diz que a língua é um sistema semântico, Halliday não se refere, apenas, ao significado das palavras, mas a todo o sistema de significados da língua (...). Os sistemas de significados geram estruturas lexicogramaticais que são igualmente plausíveis: há, então, verbos e substantivos para enquadrar a análise da experiência em processos e participantes (NEVES, 2004, p.74).

A teoria proposta por Halliday relaciona linguagem, situação e cultura sistematicamente.

2.2.2. Princípio Hologramático - a parte está no todo assim como cada parte contém praticamente a totalidade da informação do objeto representado, além de haver comunicação e influência intensa entre as partes: a língua ou linguagem como parte, está presente em todos os nichos da sociedade - ela funciona para comunicação, para o registro de fatos, para retratar o lado poético do ser humano, pode descrever/reconstruir a própria sociedade na medida que funciona como transmissora de valores dessa sociedade para as novas gerações.

Quanto à estrutura da língua, de acordo com o Paradigma Funcional, Neves (1997) afirma que todas as expressões lingüísticas se reduzem à estrutura do predicado. Assim acreditamos ser possível concluir que a partir de tal estrutura podem-se deduzir/reconstruir as inúmeras expressões lingüísticas disponíveis em qualquer língua natural.

Há ainda a afirmação de de Beaugrande (1993, apud NEVES, 1997) sobre as gramáticas terem especificações funcionais ricas e empenharem-se em acomodá-las no esquema - a descrição gramatical de um discurso contém dados amplos para auxiliar uma descrição semântica, pragmática e estilística da língua (o todo está na parte). 
2.2.3. Princípios da Retroatividade e da Recursividade - Morin (1996) afirma que a língua traduz e transfere em enunciados lineares/seqüenciais o que se manifesta como simultaneidade encadeada tanto no cérebro como na vida 'real'. Essa simplificação traria grandes vantagens para o exame ponto a ponto para o pensamento analítico e, mesmo sendo aparentemente contraditória ao princípio da retroatividade (que rompe com a causalidade linear), é uma simplificação complexificante na medida em que a língua 'gira' entre computação (informação, simbologia, memória, pragmática) e cogitação; entre o inato (adquirida filogeneticamente ao longo da hominização) e o adquirido; entre o individual e o coletivo; o pessoal e o cultural; sempre um afetando o outro como causa e produto.

Existe uma grande afinidade desse princípio com o Paradigma Funcional, especialmente no que afirma Du Bois (1993, apud NEVES, 1997) de que a gramática molda o discurso, e o discurso molda a gramática: “(...) a gramática é feita à imagem do discurso, mas o discurso nunca é observado sem a roupagem da gramática" (NEVES, 1997, p.29) - ou seja, as estruturas gramaticais são escolhidas sempre dependendo do efeito desejado para o discurso e este pode alterar a gramática; ou ainda Hopper \& Thompson (1980, apud Neves, 1997) quando afirmam que “(...) a relevância comunicativa governa a escolha das estruturas oracionais(...)" (NEVES, 1997, p.27) e Auwera (1989, apud Neves, 1997) quando afirma que há pragmática que é interna à gramática (exemplo: a colocação da topicidade como central na organização da gramática) e há pragmática que não é interna (exemplo: a visão do planejamento da língua na perspectiva da sua adaptação ao ambiente) -

é a pragmática interna à gramática que é a mais interessante para a tarefa de preparo de gramáticas (...). O paradigma funcional, como diz Camacho, é uma das alternativas relevantes para superar o problema metodológico resultante da desconsideração do papel do contexto social na interação lingüística (NEVES, 1997, p. 32).

Há ainda claro indício da presença do princípio da recursividade quando Neves fala sobre a gramaticalização:

(...) o que se postula é uma teoria de relação entre gramática e discurso, segundo a qual os processos de gramaticalização se devem não apenas à 
influência da língua como sistema gramatical, mas também à influência de fenômenos discursivos (NEVES, 1997, p. 37).

Outro ponto coincidente entre o princípio da retroatividade/recursividade do Pensamento Complexo e Paradigma Funcional fica por conta do que afirma Neves sobre a relação das propriedades lingüísticas e os parâmetros sociais: essa relação se faz em duas direções - da língua para a realidade social e desta para a língua.

Assim, de um lado, é possível entender-se que a língua monolítica pode sustentar a identidade de uma sociedade e frear sua fragmentação, mas, por outro lado, pode-se entender que a diversidade social há de configurar uma língua não monolítica, a serviço da diversidade, sem estabelecer-se uma relação necessária com fragmentação (NEVES, 2004, p.44).

2.2.4. Princípio da Autonomia/Dependência - em princípio, o Paradigma Funcional reza pelo postulado da não-autonomia da língua:

(...) a língua (e a gramática) não pode ser descrita como um sistema autônomo, já que a gramática não pode ser entendida sem referência a parâmetros como cognição e comunicação, processamento mental, interação social e cultura, mudança e variação, aquisição e evolução (NEVES, 1997, p. 2, citando GIVÓN, 1979).

Mas, como vimos no início deste capítulo, Dik (1978, apud NEVES, 1997), com sua teoria de componentes integrados, deixa claro que a língua pode sim ser vista como autônoma, apesar de dependente do meio. Trata-se de uma teoria funcional da sintaxe e da semântica que só pode ter um desenvolvimento satisfatório dentro de uma teoria pragmática, ou seja, dentro de uma teoria de interação verbal pragmaticamente adequada, mesmo que se reconheça que o funcionamento comunicativo da linguagem ocorra só por meio de arranjos sintaticamente estruturados.

2.2.5. Princípio Dialógico - Esse princípio fala da união de verdades aparentemente antagônicas, já que se complementam.

Podemos citar aqui a diferenciação que Neves (1997) faz entre os paradigmas formal e funcional que, segundo a autora, são pólos opostos do pensamento lingüístico. 
Já vimos antes que esses 'pólos' na verdade podem ser usados conjunta e complementarmente no estudo da língua, já que se trata somente de modos diferentes de observá-la.

Eis algumas diferenças citadas por Neves:

\begin{tabular}{|c|c|c|}
\hline Quadro 2 & \multicolumn{2}{|c|}{ Diferenças entre os Paradigmas Formal e Funcional } \\
\hline & Paradigma Formal & Paradigma Funcional \\
\hline $\begin{array}{l}\text { Visão da } \\
\text { linguagem }\end{array}$ & $\begin{array}{l}\text { Examina a linguagem como um } \\
\text { objeto autônomo; investiga a } \\
\text { estrutura lingüística independente } \\
\text { do uso. }\end{array}$ & $\begin{array}{l}\text { Examina a linguagem como entidade não } \\
\text { suficiente em si. }\end{array}$ \\
\hline O que é analisado & $\begin{array}{l}\text { Em primeiro lugar, a forma da } \\
\text { língua. }\end{array}$ & Em primeiro lugar, os interesses funcionais. \\
\hline Hoffmann & $\begin{array}{l}\text { Trata da estrutura sistemática das } \\
\text { formas de uma língua. }\end{array}$ & $\begin{array}{l}\text { Analisa a relação sistemática entre as } \\
\text { formas e as funções em uma língua. }\end{array}$ \\
\hline Dillinger & $\begin{array}{l}\text { Os formalistas (incluindo os } \\
\text { gerativistas) "estudam a língua como } \\
\text { objeto descontextualizado, } \\
\text { preocupando-se com suas } \\
\text { características internas - seus } \\
\text { constituintes e as relações entre } \\
\text { eles (...) a língua como um sistema } \\
\text { de sons, de frases, de signos, } \\
\text { equiparando a língua à sua } \\
\text { gramática" (NEVES, 1997, p. 42). }\end{array}$ & $\begin{array}{l}\text { Os funcionalistas "se preocupam com as } \\
\text { relações (as funções) entre a língua como } \\
\text { um todo e as diversas modalidades de } \\
\text { interação social - fixam o papel do contexto, } \\
\text { em particular do contexto social, na } \\
\text { compreensão da natureza das línguas" } \\
\text { (NEVES, 1997, p.41). }\end{array}$ \\
\hline De Beaugrande & $\begin{array}{l}\text { Estuda a língua em si mesma e por } \\
\text { si mesma (langue) - leva a uma } \\
\text { ênfase nos dados formais e seus } \\
\text { níveis, enquanto os dados } \\
\text { funcionais são atribuídos ao uso da } \\
\text { língua (parole). }\end{array}$ & $\begin{array}{l}\text { Rejeita essa atribuição e defende uma } \\
\text { perspectiva mais integrativa na qual todas } \\
\text { as unidades e os padrões da língua seriam } \\
\text { compreendidos em termos de funções. }\end{array}$ \\
\hline $\begin{array}{l}\text { O que compõe a } \\
\text { língua }\end{array}$ & $\begin{array}{l}\text { Fonemas; morfemas; palavras- } \\
\text { lexemas; sintagmas-sintagmemas. }\end{array}$ & Entonação \\
\hline
\end{tabular}

$\left(^{*}\right) \quad$ - prosódia: 'melodia' do texto enunciado;

- gramática: além de incluir os morfemas e as estruturas sintagmáticas, inclui o seu embasamento cognitivo no conhecimento que a comunidade tem de como os processos e seus participantes são organizados (ex.: se uma ação tem um iniciador);

- discurso: é a rede total de eventos comunicativos relevantes, incluindo gestos, expressões faciais, manifestações emocionais e outros.

2.2.6. Princípio da dependência das condições iniciais - segundo Kartchner, por ser um sistema complexo, a língua 'evolui'/muda: uma pequena mudança fonética, por exemplo, pode provocar grandes mudanças no futuro e até um novo dialeto, ou essa pequena mudança pode simplesmente desaparecer dependendo das condições disponíveis para isso. 
O autor indaga ainda sobre se "não seria interessante usar esse conceito para estudar as tendências que estão em marcha nas línguas de hoje?" (KARTCHNER, s/d, p. 91).

E como afirma Morin,

a língua vive. As palavras nascem, deslocam-se, enobrecem-se, pervertem-se, degradam-se, morrem. A língua vive como uma grande árvore, cujas raízes encontram-se nas profundezas das vidas social e cerebral e cujos galhos se espalham pela noosfera (o campo das idéias) (...). Ela (a língua) possui autonomia dominadora que, embora ramificada em todos os seres de espírito, dispõe da substância noológica que lhe permite impor-se aos humanos (MORIN, 2002a, p.205).

Em outras palavras, a língua é autônoma pois tem suas próprias regras, porém dependente de seu meio sócio-cultural (obedece a interesses funcionais). Mudanças ocorrem na língua no decorrer do tempo, sempre dependendo se há condições favoráveis à mudança ou não: se a sua estrutura a permite, se os seus falantes entram em acordo implícito sobre a mudança (o uso de gírias como palavras corriqueiras, por exemplo), entre outros.

Além dos aspectos apontados acima, acreditamos existir também a aproximação do Pensamento Complexo e do Paradigma Funcional na visão de Halliday (1985, apud NEVES, 1997) no que diz respeito a considerar a língua um ser vivo:

(...) cada elemento, numa língua, é explicado por referência à sua função no sistema lingüístico total. Nesse sentido, uma gramática funcional é aquela que constrói todas as unidades de uma língua - suas orações, suas expressões como configurações orgânicas (grifo nosso) de funções e, assim, tem cada parte interpretada como funcional em relação ao todo (NEVES, 1997, p.63).

Os pontos básicos nessa visão são o texto (unidade maior de funcionamento) e os itens (que são multifuncionais, pois cumprem diferentes funções).

Ainda sobre considerar a língua um ser vivo, Neves (2004) defende que a Teoria Funcionalista da Linguagem oferece aparato para avaliação da variação lingüística e suas manifestações (a língua é viva, portanto ela muda, varia, de acordo com o princípio de dependência das condições iniciais) no uso dos falantes de uma comunidade, pois essa teoria é dirigida para a questão da comunicação eficiente (competência comunicativa) dos falantes, noção que refletiria o princípio sociolingüístico de que a língua é um sistema inerentemente variável, cuja heterogeneidade não seria 
um aspecto secundário e acessório de sua estrutura, mas um fator muito importante para a expressão mais acurada de conteúdos.

Os lingüistas reconhecem a existência (e as vantagens) de um padrão valorizado, porém defendem a idéia de que a heterogeneidade é um recurso da língua que dá conta de aspectos que o padrão valorizado não dá.

Outro ponto afim entre o Pensamento Complexo e o Paradigma Funcional é o fato de ambos considerarem a língua como um sistema complexo, cujas partes são interdependentes e atuam umas sobre as outras, além de receber influência de seu meio e de ter influência sobre esse mesmo meio.

Dik apresenta, pois, a estrutura subjacente de cláusula como uma rede estratificada complexa na qual um grande número de diferentes elementos pode operar em diferentes níveis, criando toda sorte de dependências. As regras de expressão, que medeiam entre essa rede subjacente e a forma real das expressões lingüísticas, também formam uma estrutura complexa (NEVES, 1997, p.91). 


\section{Aquisição de língua materna e estrangeira - como aprendemos?}

Nenhum método é capaz de impedir que qualquer um que tenha o desejo de aprender uma língua estrangeira o faça! (REVUZ, 1998, p.216)

Como o objeto de estudo deste trabalho é a conjugação dos verbos 'ser' e 'ter' em livros didáticos de português para estrangeiros (cujo público-alvo é composto por jovens e adultos), não poderíamos deixar de tecer considerações sobre algumas das teorias mais recentes sobre aprendizagem, e de aquisição da linguagem tanto de uma primeira quanto de uma segunda língua.

Na Filosofia, Morin define aprendizagem não como somente

adquirir 'savoir-faire', mas também saber fazer aquisição de saber; pode ser a aquisição de informações; pode ser a descoberta de qualidades ou propriedades inerentes a coisas ou seres; pode ser uma relação entre um acontecimento e outro acontecimento, ou ainda a descoberta de uma ausência de ligação entre dois acontecimentos (MORIN, 1996, p. 60).

Para Morin, a elucidação da natureza da aprendizagem está ainda hoje entre o inatismo (só aprende quem já conhecia) e um aquisicionismo (só a experiência nos instrui), ambos baseados no mesmo dogma, ou seja, quanto mais inato existe, menos possibilidade de adquirir existe (inatismo); quanto menos inato, mais possibilidade de adquirir (aquisicionismo). Ambas opções são mutilantes, segundo este autor, pois dão somente uma visão parcial de como o ser humano aprende.

O Pensamento Complexo concebe a aprendizagem baseando-se na dialógica auto-eco-organizadora a partir de uma dialógica maior: do inato/adquirido/construído: "construir supõe um construtor; aprender supõe um 'a priori'; adquirir supõe um inato. $O$ aparelho neurocerebral é o construtor 'a priori' que dispõe da capacidade de aprender" (MORIN, 1996, p.60).

Nossa aptidão para aprender está ligada à plasticidade bioquímica do cérebro, suscetível de ser modelado e que tem o poder ou a virtude de formar, pois "um conhecimento adquirido pode inscrever-se duradouramente sob a forma de uma propriedade associativa estável entre os neurônios" (MORIN, 1996, p.60).

Essa propriedade associativa trabalha com a dialógica entre aparelho cognoscente, portador do já conhecido, e o meio cognoscível, fervilhante de incógnitas, 
a partir dos estímulos do meio necessários para pôr em ação e desenvolver o conhecimento cerebral.

Ainda segundo Morin, o inato é "ao mesmo tempo um adquirido e um construído do processo evolutivo cerebral, que integrou e assim inatizou os princípios organizacionais do mundo exterior, os quais vão contribuir para a aquisição de conhecimentos do mundo exterior" (MORIN, 1996, 61). O inato é na verdade um processo evolutivo espiral, comandado pela dialógica auto-eco-organizadora, e onde os termos inato/adquirido/construído se encadeiam, se permutam e se entreproduzem; o aprender é a conjunção do reconhecido e da descoberta, comporta a união do conhecido e do desconhecido.

Vemos nessas definições alguma semelhança com o que Vygotsky (1989, apud MARTINS, s/d) chama de 'low mental functions' (funções mentais elementares ou memória natural) que nascem com o indivíduo, e as 'high mental functions' (funções mentais superiores ou memória mediada) que são adquiridas ou internalizadas por meio da linguagem - são na verdade as funções mentais elementares transformadas em superiores por meio da linguagem, principal instrumento simbólico de representação da realidade.

Em outras palavras, o indivíduo possui capacidade inata para o aprendizado porque biologicamente munido para isso graças à evolução da espécie humana (ele possui a memória orgânica, muito próxima da percepção), mas adquire muitas de suas funções mentais (como o raciocínio, a atenção voluntária e a vontade, que seria a principal função, pois possibilita a emergência das demais) pela internalização de dados vividos na interação social, internalização mediada pela linguagem - as funções mentais superiores têm origem na interação social, e a fala tem grande importância nesse processo, daí também a grande importância do outro no desenvolvimento humano.

"O uso de símbolos leva o ser humano a uma estrutura específica de comportamento que foge do desenvolvimento biológico e cria novas formas de um processo psicológico baseado na cultura" (MARXISTS, s/d, s/p), isto é, a linguagem (símbolos) medeia o mundo real e os processos cognitivos, ficando esses inteiramente ligados a ela ainda durante a infância, e torna a memória natural (biológica) em memória mediada. 
Nos adultos, esse processo de mediação está extremamente desenvolvido:

para a criança pequena, pensar significa lembrar (a memória é a base de seu pensamento); mas para o adolescente, lembrar significa pensar (forma-se um link temporário por combinação artificial de estímulos). Sua memória é tão 'logicizada', que lembrar está reduzido a estabelecer e encontrar relações lógicas (...). A memória humana consiste no fato de que lembramos ativamente com a ajuda de signos (MARXISTS, s/d, s/p).

Sobre a diferença de como uma criança e um adulto aprendem uma língua, vale lembrar o que van Passel, citado por Kunzendorff, afirma sobre essa distinção:

(...) parece não haver dúvidas de que unicamente as crianças de menos de doze anos são capazes de assimilar uma língua de forma intuitiva e puramente imitativa. O adulto, por sua vez, só capta o fenômeno 'língua', como aliás qualquer fenômeno de ordem intelectual, de maneira racional e lógica, isto é, apelando para sua inteligência, não importa quais sejam o grau e o desenvolvimento dessa inteligência. O adulto, efetivamente, estuda na base da compreensão. O adulto deseja 'saber' o que faz, deseja que lhe digam 'por que' deve agir desta ou daquela maneira, assim como pretende conhecer as 'razões' pelas quais um fenômeno se apresenta desta ou daquela forma (KUNZENDORFF, 1997, p.33).

Além disso, a adequação do método do curso aos objetivos do aluno, colocandoo no centro do aprendizado (e portanto abandonando-se os cursos lineares), mostra-se, segundo Kunzendorff (1997), bastante produtivo. Além da adequação aos objetivos, a adequação ao nível de conhecimento que o aluno possui, tanto lingüístico quanto cultural, mostra-se tão produtivo quanto respeitar o ritmo de aprendizado, esclarecer os objetivos do curso para o aluno e, finalmente, conhecer a língua materna dele para que os pontos mais problemáticos possam ser trabalhados com eficiência.

A convivência com falantes nativos também precisa ser incentivada para que o aluno encontre oportunidade de testar hipóteses e adequar sua L2/LE ao uso com esses falantes ${ }^{10}$. Kuzendorff ainda defende privilegiar a língua padrão no ensino formal de português para estrangeiros, já que, segundo ela, a maioria dos alunos, por serem

\footnotetext{
${ }^{10}$ Como enfocamos o aluno em condição endolíngüe, ou seja, ele aprende o português no Brasil, onde se fala essa língua, incentivá-lo a ir a museus e pontos turísticos em visita monitorada, ou mesmo freqüentar o teatro, clubes, etc., trariam ótimas oportunidades para esse convívio com falantes nativos. Fora do Brasil, ou seja, em uma situação exolíngüe, isso poderia acontecer por meio de apresentações (palestras) de nativos, visitas a casas de cultura, via internet, em contato com materiais autênticos como a música e textos da mídia, por exemplo, que, até certo ponto, substituiriam satisfatoriamente o convívio direto com falantes nativos.
} 
executivos ${ }^{11}$, necessitam aprender essa variante da língua para uso durante o trabalho: a passagem do padrão para o coloquial seria muito mais simples do que o contrário.

Quando se trata de aprendizagem, Vygotsky (1991) fala em Zona de Desenvolvimento Proximal que, segundo ele, é uma abordagem inédita do assunto. Vygotsky afirma que o aprendizado da criança começa muito antes de ela freqüentar a escola, ou seja, qualquer situação de aprendizado na escola tem uma história prévia, e esse aprendizado escolar, por ser sistematizado, está voltado para a assimilação de fundamentos do conhecimento científico.

O autor separa o desenvolvimento da criança (do ser humano, portanto) em dois níveis: o nível de desenvolvimento real e a zona de desenvolvimento proximal. 0 primeiro, o nível de desenvolvimento real, inclui as capacidades mentais já amadurecidas da criança, isto é, tudo aquilo que a criança pode fazer por si mesma sem a ajuda de alguém mais experiente. Já o segundo nível

é a distância entre o nível de desenvolvimento real, que se costuma determinar através da solução independente de problemas, e o nível de desenvolvimento potencial (que ainda está além da capacidade de entendimento do aluno), determinado através da solução de problemas sob a orientação de um adulto ou em colaboração com companheiros mais capazes (VYGOTSKY, 1991, p. 97).

É este o nível (zdp = zona de desenvolvimento proximal) que permite delinear o futuro imediato da criança e seu estado dinâmico de desenvolvimento. Além disso, o que é zdp hoje, amanhã será nível de desenvolvimento real (ndr): “... o aprendizado humano pressupõe uma natureza social específica e um processo através do qual as crianças penetram na vida intelectual daqueles que as cercam" (VYGOTSKY, 1991, p. 99). Um aspecto essencial do aprendizado, ainda segundo Vygotsky, seria o fato de ele (o aprendizado) criar a zdp:

“...o aprendizado desperta vários processos internos de desenvolvimento, que são capazes de operar somente quando a criança interage com pessoas em seu ambiente e quando em cooperação com seus companheiros. Uma vez internalizados, esses processos tornam-se parte das aquisições do desenvolvimento da criança (...). O aprendizado é o aspecto necessário e universal do processo de desenvolvimento das funções psicológicas

\footnotetext{
${ }^{11}$ Hoje sabemos que não somente executivos, mas diplomatas, acadêmicos e respectivas famílias também vêm ao Brasil por motivos variados e para uma estada por tempo definido por aqui. Caso diferente da grande imigração de latino-americanos e de orientais que vêm para cá em busca de uma vida melhor, e que muitas vezes permanecem em seus 'guetos' por não dominar o português.
} 
culturalmente organizadas e especificamente humanas" (VYGOTSKY, 1991, p. 101).

Em outras palavras, o processo de aprendizagem é histórico-cultural ou históricosocial, pois a aprendizagem ocorre durante toda a vida e em interação com outros, e a aprendizagem atual recebe influências de aprendizagens anteriores (vemos aqui o princípio de dependência das condições iniciais) e influencia aprendizagens futuras. Nesse aspecto, podemos dizer que a aprendizagem é contínua.

Por fim, o aprendizado converte-se em desenvolvimento, uma vez que progride de forma mais rápida e, somente quando terminado o processo de aprendizagem, os processos de desenvolvimento se iniciam. De uma forma retroativa (vemos aqui afinidade com o princípio de retroatividade do Pensamento Complexo), o aprendizado possibilita o desenvolvimento, e este possibilita a aprendizagem.

Mas, afinal, como aprendemos? Como alcançamos o nível de desenvolvimento potencial? Como chegamos ao conhecimento e, conseqüentemente, a esse desenvolvimento?

O próprio Vygotsky (1989, apud por DELGADO, 2003) afirma que não é possível transmitir conteúdos a um aluno passivo: para que haja aprendizagem eficaz, é necessário o envolvimento ativo do aluno na elaboração de conceitos (é a reintrodução do sujeito-estrategista no processo de acordo com o Pensamento Complexo).

Além disso, não há como conceber a aprendizagem sem a orientação planejada e intencional do professor e do material didático, já que, como afirma Morin,

o conhecimento deve dispor de certezas (do fixo, do estável, do repetitivo, do predizivel nos quais a informação pode revelar a sua mensagem) para enfrentar e resolver a incerteza (...) todo o aumento dos conhecimentos estáveis (redundâncias) aumenta as possibilidades de conhecimento singular/circunstancial (informação), que por sua vez aumentam as possibilidades de conhecimento estável, e tudo isso aumenta as possibilidades estratégicas de conhecimento e ação (MORIN, 1996, p. 63).

Morin, assim como Vygotsky, defende a idéia de que dependem da interação social a aprendizagem e o desenvolvimento da individualidade, da cerebralização, da afetividade, das possibilidades de escolha e de cisão, da curiosidade (aquela humana, com fins práticos porém aliada ao prazer ao mesmo tempo) e das possibilidades de emancipação do conhecimento. 
Baseado no Pensamento Complexo, Demo (2002), afirma que o conhecimento e a aprendizagem são atividades humanas que expressam processos não lineares, são imateriais e dependem da base material fisiológica. Ambos implicam processos seletivos tipicamente reconstrutivos, e sua característica mais forte "parece ser a capacidade de fazer história própria, reduzindo substancialmente a dependência de fatores externos ou de hereditariedade" (DEMO, 2002, p. 123).

Segundo esse autor, a inteligência é a habilidade de lidar com a complexidade não linear mais do que manipular códigos lógicos, e saber pensar é, antes de tudo, habilidade de autocrítica, de questionamento crítico (para ir além das ideologias, das aparências, sem a ambição de encontrar um ponto final), de saber cuidar, inovar, acreditar, comunicar, além de habilidade lógica.

Por esse motivo, Demo diz-se contra aulas meramente reprodutivas ou instrucionistas, pois são basicamente um jogo de poder de cima para baixo inerente à sociedade, e não oferecem ao aluno a possibilidade de manejar o conhecimento por si mesmo e de inovar o próprio conhecimento - esse tipo de aula nega a alteridade do aluno, apaga o sujeito, treinando-o (adestrando-o) para porta-voz, literalmente: "como tática linear que é, atrapalha sobremaneira a dinâmica não linear ambivalente da aprendizagem" (DEMO, 2002, p. 135).

Quanto a esse ponto, Almeida Filho afirma que "está superada a visão do professor como emissor e do aluno como receptor numa relação opressiva de cima para baixo. Os papéis (...) precisam ser intercambiados numa relação interativa de comunicação de fato" (ALMEIDA FILHO, 2002, p.15).

Santos (2003) inicia sua definição de aprendizagem descrevendo, antes, o ser humano. Segundo ela, ao contrário do que pregava a filosofia cartesiana ('o homem é um ser racional'), hoje sabemos que o ser humano é um ser baseado no paradoxo do uno e do múltiplo, e em permanente crise, esta sendo o prenúncio de uma nova construção, e, como toda crise, desconfortável mas necessária ao desenvolvimento intelectual e emocional. O ser humano é a conjunção de todas as áreas de conhecimento - assim, todos os conhecimentos são válidos para o seu estudo.

Para Santos, baseada claramente no Pensamento Complexo de Morin, o sujeito é uma complexidade "que se constrói mobilizando dimensões mentais e corporais por 
meio da comunicação com outra complexidade, que é o mundo exterior" (SANTOS, 2003, p. 19).

A construção da identidade de sujeito acontece ao se fazerem concessões no cotidiano, se auto-regulando de conformidade com o meio, porém mantendo sua integridade, sua atitude de auto-organização. A autonomia desse sujeito está em processo de permanente construção, depende das condições sócio-culturais, mas é ao mesmo tempo independente por causa da característica auto-organizadora que possui, pois elabora suas próprias teorias para dar sentido à vida, teorias que devem renovarse por meio do contato com a sociedade para que não enclausurem e façam adoecer quem as formula.

A noção de pertencimento do sujeito vem enfraquecendo em nosso mundo moderno, deixando no ser humano o sentimento de orfandade, desamparo e incapacidade ante uma sociedade em ritmo acelerado de mutação. Uma das únicas maneiras de superar esse sentimento de não-pertencimento estaria na herança cultural, que, apesar de condicionar o indivíduo, deixa nele a sensação de pertencer a um grupo. Além disso, com a fragmentação do sujeito (pois vive em constante crise), a autonomia, a reflexividade e a visão de mundo tornam-se imprescindíveis.

Outro aspecto do sujeito é o fato de basear suas decisões na razão porém sempre colorida por emoções, além de seu pensamento estar sempre encaixado nas sensações e nos processos corporais que contribuem para a multiplicidade cognitiva.

Para Santos (2003), o sujeito, quando aprende, sofre uma mudança estrutural em todo o organismo, pois criam-se novas redes de interconexões neuronais para conviver com as transformações ocorridas em seu meio, ou seja, o homem, ao aprender, modifica-se.

A construção do conhecimento não se faz somente pelos canais lingüísticos e por ordenamento lógico-matemático em progressão: há também movimentos retroativos e recursivos, é o movimento em espiral visto em Morin (1997), no qual o produto retroage sobre o processo e sobre a causa, incorporando-os e modificando-os. $O$ conhecimento (aqui incluído o conhecimento da língua), além de promover a competência profissional, é um instrumento para a construção e reconstrução da percepção de mundo - constitui a essência do sujeito e é provisório e dinâmico. 
Santos (2003) também fala sobre o ato de compreender, que, para ela, significa apreender o significado e ver o objeto ou acontecimento em suas relações com outros objetos ou acontecimentos. O significado é um feixe de relações, portanto o processo de compreendê-lo requer considerar as interconexões entre o todo e as partes (Princípio Hologramático), já que a parte (uma palavra, por exemplo) só pode ser entendida em função do todo (o texto ou a situação em que é usada essa palavra, sempre polissêmica).

Como diria Almeida Filho, "uma abordagem contemporânea de ensinar línguas toma entre outras coisas o sentido ou a significação como requisito central e o compreende como função de uma relação. Algo terá sentido se for tomado em conjunto e em relação a alguma outra coisa". (ALMEIDA FILHO, 2001, p. 15). E ainda Santos,

considerar o processo holográfico (hologramático) no processo ensino/aprendizagem torna o aprender uma atividade prazerosa. Faz com que cada um encontre sentido para o conhecimento. Este é o desafio na construção de uma outra Didática. Uma Didática que considere o ser como sinônimo do saber, o saber como uma razão de ser, uma relação simbiótica e não dicotômica como na Pedagogia Tradicional (SANTOS, 2003, p.30).

Para esta autora, a participação seria tanto condição como resultado da aprendizagem e, para que a educação seja muito mais eficiente e a construção do conhecimento seja facilitada, os diferentes aspectos humanos devem ser levados em conta: além da dimensão racional, as dimensões poética, ética, utópica, histórica, social, cultural, filosófica, subjetiva e corporal precisam ser consideradas por qualquer metodologia séria.

Além dessas dimensões, a emocional se mostra de grande importância, já que as emoções acompanham o processo ensino/aprendizagem e são a mola propulsora de um ensino criativo e renovador dos conhecimentos. Pensar/sentir/atuar são uma unidade integrada, pois uma leva à outra. O homem constitui um ser uno com multirreferencialidade (cerebral, cultural, social, histórica) - "como questão educacional, revela-se como uma rede de articulação do diverso, interconectado. Cada elemento se articula com outros. Quando se modifica a parte, modifica-se o todo, segundo o princípio holográfico (hologramático)" (SANTOS, 2003, p.44).

Em uma aproximação à noção de internalização de Vygotsky, Santos afirma que "na socialização, as informações recebidas pelos indivíduos permanecem justapostas e, 
às vezes, contraditórias até o momento da reflexividade e da sua assimilação pelo mundo interior" (SANTOS, 2003, p. 45), ou seja, deve decorrer o tempo necessário para que uma 'digestão' cognitiva aconteça, e o processo de internalização termine:

"em contato com o meio, o indivíduo, dotado de bagagem hereditária, perturba-se, desequilibra-se e, para superar o desequilíbrio, constrói novos esquemas ou organizações mentais. Na verdade, o seu desenvolvimento é uma sucessão de estruturas de conhecimento, estruturas de crenças que, ao se desequilibrarem, provocam a necessidade de uma síntese superior, incorporando a estrutura anterior" (SANTOS, 2003, p.57).

Santos fala no conceito de 'bricolagem' de G. Lapassade (s/d, apud SANTOS, 2003), que define o conhecimento do sujeito como resultado sempre inacabado de uma combinação de disciplinas, sendo realizado como uma atividade artesanal, uma bricolagem. O conhecimento é tecido de tal forma que as disciplinas não podem ser reduzidas umas às outras. Sua construção não é uma linha de acertos em progressão, mas é o resultado tanto de erros quanto de acertos (aqui, erro deve ser encarado como um processo natural da descoberta): "quem pensa erra. A estrutura intelectual do homem não é uma estrutura pronta e acabada. Ela é cheia de buracos. Portanto não se deve ter medo de errar" (SANTOS, 2003, p. 67).

Santos ainda fala em conhecimento transdisciplinar que, a seu ver, restaura a autoconfiança, a autovalorização, a auto-estima, já que prepara o indivíduo para confiar em suas próprias decisões e constrói a sensação de poder pessoal e de autonomia na interação com outros indivíduos (também porque tendemos a introjetar o julgamento alheio sobre nós mesmos), no questionamento e na reformulação permanente em relação ao mundo. A transdisciplinaridade transgride a dualidade que opõe os pares sujeito/objeto, subjetividade/objetividade, matéria/consciência, natureza/divino, simplicidade/complexidade, reducionismo/holismo, diversidade/unidade. Ela é multidimensional e multirreferencial, pois diz respeito à dinâmica dos diferentes níveis de realidade.

Além desse aspecto, nas interações sociais, seja na sala de aula, seja no trabalho, o indivíduo precisa ser aceito pelo outro para desenvolver-se. Também, quanto mais contextualizado o ensino, muito maior a possibilidade de que ele resulte em aprendizagem significativa - ao contextualizar, usa-se uma espécie de rede polivalente que atinge os diferentes estilos cognitivos (nenhum indivíduo aprende como 
o outro), mobilizando-se a motivação. Motivação essa que depende de aprendizagens anteriores, nível de amadurecimento, de expectativa, de envolvimento emocional - o novo deve sempre encontrar relações com essas noções anteriores para que possa ser assimilado.

A motivação deve basear-se na busca, processo muito mais atraente do que a simples memorização de um conhecimento previamente elaborado. Dessa forma, segundo a autora, ocorre a aprendizagem:

um organismo é uma estrutura altamente autoconstrutiva em interação com o meio-ambiente, ele se autoproduz. A aprendizagem significativa tem por meta fazer com que o conhecimento repercuta na auto-organização dos indivíduos, provocando neles uma nova estrutura de explicação da realidade, superando o pressuposto cartesiano da realidade válida para todos (SANTOS, 2003, p.92).

Ou seja, a rede de interações neuronais, extremamente complexa e dinâmica, vai criando outras conexões ou estados gerais qualitativamente novos no cérebro esses saltos qualitativos são na verdade uma nova organização das sinapses neuronais, nas quais o sistema cerebral como um todo se modifica de alguma forma.

Santos fala também na necessidade de flexibilidade ante a diversidade, pois trata-se de uma habilidade histórica que possibilitou a sobrevivência do ser humano. A falta de flexibilidade provoca a exclusão, o excesso dela leva à desorganização. É necessária uma flexibilidade diante de um mundo em constante mudança, a qual depende da variedade e da diversidade - quanto mais diversidade há, mais flexível e dinâmico será o sistema, por isso a transdisciplinaridade mostra-se tão importante. Citando Paulo Freire, Santos afirma que amar o igual é como amar a si mesmo: o desafio está em amar o diferente, o diverso.

Neves (2004), por outro lado, afirma que essa qualidade de amar o diferente pode ser facilmente resgatada no ser humano, pois o homem, segundo essa autora, ama a diferença, e quando ela não existe, ele a cria. Sobre esse ponto, Martins afirma que o homem constrói sua identidade exatamente no confronto com as diferenças, e seu conhecimento se constrói em primeiro lugar na interação:

para o sociointeracionismo, o desenvolvimento se produz não apenas por meio da soma de experiências, mas, e sobretudo, nas vivências das diferenças. O aluno aprende imitando, concordando, fazendo oposição, estabelecendo analogias, internalizando símbolos e significados, tudo isto num ambiente social e historicamente localizado (MARTINS, s/d, p. 120). 
Ainda sobre a interação social, ou a interação do eu com o outro, com o diferente, no paradigma funcional, Neves afirma que a

aquisição lingüística se desenvolve na interação comunicativa entre a criança e seu ambiente; aos fatores genéticos se atribuem apenas aqueles princípios subjacentes que não podem explicar-se por essa interação. 0 processo de aquisição da linguagem é fortemente co-determinado por um 'input' altamente estruturado de dados lingüísticos, apresentados à criança em contextos naturais e adaptados ao nível de sua competência comunicativa (NEVES, 1997, 45).

Neves compara novamente o paradigma formal e o funcional para falar de aquisição/aprendizado, afirmando que cada um desses paradigmas possui hipóteses opostas sobre as origens da gramática na linguagem da criança:

A primeira posição acentua a natureza arbitrária do formalismo gramatical, sugerindo que as línguas podem ser aprendidas somente porque as crianças têm algum tipo de conhecimento apriorístico a respeito da estrutura e do conteúdo de um componente gramatical e autônomo abstrato (NEVES, 1997, p. 144).

O paradigma funcional chama atenção para as restrições funcionais sobre a forma gramatical, sobre o 'ajuste' natural entre estrutura de superfície do enunciado e a função comunicativa para a qual destina-se a gramática - "as línguas podem ser aprendidas porque as crianças estão resolvendo o problema da comunicação e descobrindo por si mesmas as restrições que determinam a forma da gramática" (NEVES, 1997, p. 145). A aquisição da gramática (parte da língua) é guiada por estruturas de comunicação pragmáticas e semânticas, que interagem com as restrições da atuação, à emissão da cadeia sonora na fala.

\subsection{A aquisição de uma segunda língua (L2/LE)}

Revuz (1998), do campo da Psicanálise, chama a língua materna de 'lingua fundadora' de cada indivíduo, já que a criança é intensamente falada desde muito pequena por sua mãe ou por quem cuida dela - "cada um que se ocupa da criança fala dela, coloca em palavras o que percebe dela, de seu 'jeito de ser', de suas semelhanças, de suas necessidades" (REVUZ, 1998, p. 218), e não há como a criança se subtrair dessa realidade, já que desde tão cedo está exposta à língua. 
A descoberta da palavra e a experiência em relação ao outro são indissociáveis, já que o sistema lingüístico sempre vem impregnado por um sistema de valores presente na sociedade onde a criança cresce, sistema esse transmitido principalmente pelo círculo social mais próximo à criança (fato que prova que a língua não é somente um instrumento de comunicação, mas o meio de se relacionar com o mundo que nos cerca e conosco mesmos, no processo de construção permanente do 'eu').

Cria-se uma verdadeira associação afetiva com a 'língua fundadora', como quer Revuz, ou com a Língua Materna, como citam tantos outros. Essa associação jamais se repete ao se aprender uma segunda língua, já que a experiência de se ser criança pequena nessa segunda língua geralmente não é possível: as palavras passam a ter menor carga de valor, já que pouco contaminadas pelo sistema de valores da língua materna, além de a língua estrangeira confrontar o aprendiz com unidades de significação desprovidas de sua carga afetiva. Assim, a entrada em uma língua estrangeira é sempre racional.

Além disso, muitos indivíduos criam obstáculos inconscientes para o aprendizado dessa outra língua, ou dessa língua do outro, já que o aprendizado de uma língua estrangeira vem questionar a relação entre o indivíduo e sua língua materna - teme-se o outro, o diferente e, acima de tudo, de tornar-se o outro, já que quanto mais se domina uma língua, maior o sentimento de pertencimento àquela cultura que tal língua veicula.

Revuz acredita que uma forma de ajudar tais indivíduos a superar sua resistência ou dificuldades em aprender uma língua estrangeira estaria na observância de dois momentos especiais em que a língua estrangeira incide sobre a relação indivíduo / língua materna: a diferença entre os universos fonéticos e as diferenças entre as maneiras de construir as significações.

Essa tensão ao se aprender uma língua estrangeira para algumas pessoas é amenizada quando se passa a aprender a escrita, já que o acesso a enunciados completos e dotados de sentido vem amenizar o corpo-a-corpo com a dimensão fonética. Além disso, só o fato de se ter tido acesso à linguagem por meio de uma primeira língua, já traria a possibilidade de se aprender uma segunda língua, e quanto maior o número de línguas aprendidas, mais facilitada seria a aprendizagem da línguaalvo. 
Quanto às etapas de aquisição de língua materna e de uma segunda língua, Germain (1996) afirma que um bom número de pesquisadores acredita que tais etapas sejam as mesmas, assim como a ordem de aquisição das estruturas gramaticais.

Então, quais seriam os fatores externos que influenciariam de maneira importante no desenvolvimento interno de uma L2/LE?

O próprio Germain tenta trazer algumas respostas a essa pergunta quando descreve a hipótese de Krashen para explicar o ritmo de desenvolvimento de uma L2/LE em ambiente escolar: é a fórmula I + 1, ou seja, um input ${ }^{12}$ de um grau superior ao nível atual de competência do estudante (o input compreensível). Para que a linguagem se desenvolva, é necessário e suficiente, segundo essa hipótese, que o estudante esteja imerso em atividades de compreensão, tanto orais quanto escritas: em primeiro lugar viria a compreensão, depois a fala que surgiria espontaneamente.

Germain (1996) afirma quanto a essa hipótese que, no momento, porém, acredita-se que a compreensão é condição necessária, mas não suficiente para a produção da fala. Para este autor, uma boa explicação para o ritmo de aquisição, seja de uma primeira língua, seja de uma língua estrangeira, parece vir da interação social que, segundo ele, em princípio se trataria de qualquer troca de palavras entre no mínimo duas pessoas.

Aprende-se e adquire-se a língua em todos os seus meandros exatamente por esse movimento de vai-e-vem entre os interlocutores, numa intensa negociação de significados (entenda-se por negociação qualquer modificação da linguagem atribuída a ajustes na conversação).

Essa negociação também depende da própria natureza da tarefa lingüística troca de informações, lacunas a completar, decisões a tomar, questões a debater, problemas a resolver, etc. - que determina o ritmo da aquisição lingüística. Citando Duff (1986), Germain explica que a resolução de problemas (tarefa interacional convergente) é preferível ao debate (tarefa interacional divergente) no que concerne ao número de questões levantadas pelos estudantes, ao número de questões de ordem referencial, ao número de pedidos de confirmação. Uma situação de debate, porém, pode envolver esforços verbais mais extensos e formas lingüísticas de maior complexidade.

\footnotetext{
${ }^{12} \mathrm{O}$ input é toda informação recebida. O intake é a informação que de fato foi assimilada.
} 
Outra tarefa lingüística interessante, segundo o autor, seria o exercício em duplas, quando um possui informações que o outro não possui: "quando colocamos os alunos em uma situação na qual eles precisam fazer perguntas ao parceiro para executar a tarefa pedida, os resultados são superiores, comparativamente, às situações nas quais a troca de informações é opcional" (GERMAIN, 1996, p.96).

Ao negociar o significado do que é dito, o estudante obriga seus interlocutores a adaptar-se ao seu nível de compreensão da linguagem, e a quantidade de intake (o que realmente é entendido) aumenta significativamente.

Essa interação com os colegas ou com pessoas mais experientes na língua-alvo permite "pôr em movimento os processos internos, permitindo a formação de vínculos entre o conhecimento que o indivíduo já possui e os novos conhecimentos a serem adquiridos" (GERMAIN, 1996, p.97).

Assim, o autor confirma o que Vygotsky intuía - um processo interpessoal se transforma em um processo intrapessoal - "...conceber-se-iam as dinâmicas sociais enquanto mecanismo das construções cognitivas individuais e não enquanto simples fatores externos que evolvem paralelamente às estruturas cognitivas" (GERMAIN, 1996, p. 98). A noção-chave dessa teoria interacionista é o conflito sócio-cognitivo visto como fonte de mudança do indivíduo, numa clara afinidade com o que Santos (2003) afirmou sobre o sujeito como alguém em constante 'crise', porque em constante mudança por causa de sua interação com o outro.

Menezes, s/d, fala da existência de um ponto de emergência de aprendizagem semelhante ao 'limite do caos' de Lewin (1994, apud MENEZES, s/d), já que este autor encara o processo de aquisição lingüística como algo tão complexo e dinâmico quanto os sistemas complexos:

\begin{abstract}
estímulos pequenos podem levar a conseqüências dramáticas. Isso é freqüentemente caracterizado como o chamado efeito borboleta - uma borboleta bate as asas na floresta amazônica e põe em movimento acontecimentos que levam a uma tempestade em Chicago. Na próxima vez que a borboleta bate as asas, entretanto, não acontece nenhuma conseqüência meteorológica" (MENEZES, s/d, s/p).
\end{abstract}

O limite do caos aconteceria no bater das asas da borboleta, ou seja, dependendo das condições iniciais (de aprendizados anteriores, do ambiente, da atitude do professor, da interação com colegas, etc.): um pequeno estímulo pode 
provocar o desequilíbrio de todo o sistema e causar uma reação em cadeia até o 'limite do caos' - momento extremamente criativo em que a mente humana cria, ou melhor, reconstrói o conhecimento, e a aquisição acontece. É o ponto de emergência da aprendizagem que acontece de forma diferente para cada indivíduo e para cada situação.

Esse ponto de emergência de aprendizagem aproxima-se do que acontece no que Vygotsky chama de zona de desenvolvimento proximal (zdp) ou do que Krashen classifica de input compreensível, com as devidas restrições, claro.

Menezes propõe um modelo de aquisição lingüística que abarca essas duas teorias e vai além delas:

proponho, então, que um modelo de aquisição de línguas deva ser pensado como um conjunto de conexões de um sistema dinâmico que se move em direção ao 'limite do caos', ponto de transição, ou seja, uma zona de criatividade com potencial máximo de aprendizagem. A dinâmica dessas conexões faz com que esse sistema funcione como um todo indivisível onde cada parte só é produtiva se estiver em constante interação com as outras e não como entidade independente. Como em uma geometria fractal, em um caleidoscópio, há possibilidades infinitas de combinações dessas partes que constituem os fractais do processo de aquisição. Pequenas alterações poderão provocar mudanças substanciais, como efeito de um seixo que rola e desencadeia uma avalanche (MENEZES, s/d, s/p).

Antes de nos atermos à proposta de Menezes, cabe um pequeno esclarecimento do que seria um fractal. Mandelbrot (1977, citado por GLEICK, 1989) foi o criador da dimensão fractal, uma vez que o ponto (dimensão zero), a reta (uma dimensão: o comprimento), o plano (duas dimensões: a largura e o comprimento) e o cubo (três dimensões: comprimento, largura, profundidade) não espelham o mundo como ele realmente é, ou seja, cheio de curvas, reentrâncias, irregular: a nova geometria espelha um universo que é irregular e não redondo; áspero e não liso. É a geometria das reentrâncias, depressões, do que é fragmentado, torcido, emaranhado e entrelaçado.

Como o universo exibe freqüentemente uma 'irregularidade regular', o fractal mostrou-se a abstração ideal para refletir as formas desse universo, já que sua principal característica é a sua simetria nas mais variadas escalas (característica da autosemelhança, isto é, a recorrência, um padrão dentro de outro padrão). Ou seja, o fractal (ou dimensão fracionada) pode demonstrar acontecimentos regulares dentro de fatos aparentemente caóticos: "a auto-semelhança é uma característica facilmente identificável. Suas imagens estão por toda parte na cultura - no reflexo infinitamente 
profundo de uma pessoa entre dois espelhos, ou na caricatura de um peixe que come um peixe menor, etc." (GLEICK, 1989, p.98).

$\mathrm{Na}$ Anatomia, por exemplo, "a abordagem fractal abarca toda a estrutura em termos das ramificações que a produzem, ramificações que se comportam de maneira coerente, das grandes às pequenas escalas" (GLEICK, 1989, p.103). Os exemplos oferecidos por Gleick são os pulmões, que são feitos de modo a acomodar uma enorme área de superfície; as artérias, que são grandes superfícies que se bifurcam e se reproduzem em superfícies menores auto-semelhantes às primeiras: "Mandelbrot passava naturalmente das árvores pulmonares e vasculares para as árvores botânicas reais, árvores que precisam captar o sol e resistir ao vento, com ramos fractais e folhas fractais" (GLEICK, 1989, p. 104). É claro que, com a invenção dos telescópios e microscópios, veio a compreensão de que cada mudança de escala provoca novos fenômenos e novos tipos de comportamento. Porém, como afirma Gleick, as comparações entre pequeno e grande e a observação das relações entre as diferentes escalas mostraram-se bastante produtivas.

Menezes (s/d) em clara identificação com o paradigma complexo, de alguma forma, adaptou a geometria dos fractais à aprendizagem de línguas: "assim, como o redemoinho se forma pelo contínuo de formas auto-semelhantes em conexão, a aprendizagem de línguas seria o resultado de um contínuo de processos autosemelhantes(...)" (MENEZES, s/d, s/p).

Cada fractal (subsistema) deste modelo se subdivide em outros fractais, e estes representam variáveis que podem influenciar todo o sistema de maneira imprevisível, já que não se trata de entidades estanques, mas de elos de uma mesma rede de conexões.

Menezes divide o fractal de aquisição nos seguintes fractais ou subsistemas: biocognitivo (língua materna, idade, gênero/identidade, personalidade, estilos cognitivos e sensoriais, algumas estratégias de aprendizagem), interação (real, simulada, virtual, negociada, com grupo, em par, centrado no professor, com outros alunos, com nativos ou com falantes mais competentes), input (formal, não verbal, comunicativo, artificial, autêntico, esporádico, contínuo, oral, escrito, variado), contexto sócio-histórico (sala de aula, o ambiente natural, o estímulo, o feedback, a cultura, o grupo, os falantes, a oportunidade, o tempo, o espaço), automatismo (os sons, a entonação, as estruturas, o 
léxico, a colocação, os gêneros, os padrões textuais, os padrões discursivos, as normas interacionais), afiliação (a identidade, o preconceito, o deslumbramento, a integração, os estereótipos, a proximidade, o contexto político, o inconsciente, o status, 0 sentimento de pertencimento), e afetivo (crenças, medo, ansiedade, atitude, autoestima, história de aprendizagem, autonomia, tipos de motivação como a integrativa, a instrumental, a política, a afetiva). As possibilidades de combinações entre cada fractal (subsistema) são infinitas.

A própria Menezes nos fornece exemplos como o da 'interação' que, para um indivíduo, pode estar conectada à ansiedade gerada pela crença de que ele não tem aptidão para aprender a língua e, conseqüentemente, terá dificuldade para interagir na língua estrangeira. Em outros movimentos dos subsistemas, a interação poderia estar conectada ao contexto social, na interação face-a-face, na qual o aluno teria tido uma boa experiência que alimenta a sua auto-estima, etc.

Segundo a autora,

o modelo aqui proposto explicaria tanto a aquisição de segunda língua como de língua estrangeira. $\mathrm{O}$ que distinguirá a aquisição delas será o conjunto de variáveis do contexto, mais especificamente, se a língua é aprendida e usada no país de origem ou se é aprendida em paios onde se fala uma língua diferente da que se está aprendendo (MENEZES, s/d, s/p).

Além disso, o modelo prega, assim como no Pensamento Complexo, a autonomia do aprendiz, que é visto como parte central do processo de aquisição e agente de sua própria aprendizagem, e não como algo que toma forma de acordo com os métodos utilizados ou o professor. Cada indivíduo possui uma dinâmica própria de aprender, dinâmica essa intrínseca ao seu sistema complexo de aprendizagem (por isso, a flexibilidade está presente nesse processo).

Por ser flexível e autônomo, o aprendiz pode lançar mão de estratégias para compensar os limites de seu conhecimento da língua, como nomear tudo o que vê pela frente, utilizar o dicionário, ler muito, consultar o professor ou os colegas, solicitar esclarecimentos de seu interlocutor, até 'criar' novos vocábulos a partir das possibilidades da língua, etc., e assim restaurar o equilíbrio na interação com o texto ou com outros falantes.

Menezes acredita que a teoria dos sistemas complexos seja capaz de explicar fenômenos como: os períodos de estabilidade seguidos por 'explosões' e mudanças na 
aprendizagem (quando ocorre a zdp de Vygotsky ou o caos criativo); o fato de nem todos os aprendizes se beneficiarem igualmente das mesmas estratégias de ensino e aprendizagem; a necessidade das conexões cognitivas e sociais para que o sistema funcione; por causa da característica de auto-organização do sistema, nem sempre a gradação de dificuldades lingüísticas no livro didático garante a aquisição daquela língua; pequenos estímulos podem levar a conseqüências imprevisíveis, positivas ou negativas, como pequenas atitudes do professor, por exemplo.

Além disso, há o que a autora chama de 'atratores estranhos' presentes em qualquer sistema complexo, portanto no da aprendizagem de segunda língua. Ou seja, basta 'aquecer' o processo da aprendizagem, como na necessidade do uso da L2/LE em determinadas situações, por exemplo, para que os atratores estranhos (ou fatores externos à L2/LE) passem a agir - podem ser os interesses do aluno, um assunto aparentemente aleatório que surgiu em sala, ou, como afirma Almeida Filho (2002) quando o aluno recorre às maneiras de aprender da sua região, etnia, classe social, grupo familiar, enfim, a abordagens que evoluem para tradições e que, a nosso ver, configurariam também os tais atratores estranhos, algumas vezes incompatíveis com a abordagem de ensino do professor. A própria língua materna nunca deixa de ser um desses atratores, já que facilmente observamos o uso de estruturas ou pronúncia da LM na L2/LE ou, antes, na interlíngua (IL), essa "língua de transição do aluno entre a língua nativa e a língua-alvo em certa altura do processo de aprendizagem" (MOITA LOPES, 1996, p.114).

Quanto à aprendizagem de uma L2/LE ou língua estrangeira, Almeida Filho fala em dois tipos de aprendizagem - a formal (a da escola) e a subconsciente:

uma que busca o aprender consciente, monitorado, de regras e formalizações, típicos da escola enquanto instituição controladora do saber, e outra que almeja a aquisição subconsciente quando o aprendiz se envolve em situações reais de construir significados na interação com outros falantes/usuários dessa língua (ALMEIDA FILHO, 2002, p.12).

Para o autor, existe uma abordagem contemporânea de ensinar línguas que define aprender uma segunda língua como aprender a significar nessa L2/LE, implicando isso em relacionar-se com outros em busca de experiências válidas, pessoalmente relevantes, capacitadoras para novas compreensões - "é crescer numa 
matriz de relações interativas na língua-alvo que gradualmente se desestrangeiriza para quem a aprende" (ALMEIDA FILHO, 2002, p.15).

O autor defende a abordagem comunicativa de ensino, já que nela podem-se trocar informações e, principalmente, negociar sentidos por meio da interação social, em um processo contínuo e jamais acabado de construção do conhecimento: "os participantes da interação social são sujeitos históricos cujas trajetórias se aliam a capacidades intrínsecas distintas para modular a construção de discurso, geralmente num processo de negociação cujo objetivo é alcançar compreensão mútua (...) (ALMEIDA FILHO, 2002, p. 15)".

Almeida Filho também chama atenção para as dificuldades do aprendizado do Português por hispano-falantes, já que as duas línguas, a materna e a língua-alvo, estão aparentemente tão próximas: a própria atitude do professor em relação aos 'erros' cometidos pelos alunos hispano-falantes precisa, segundo esse autor, ser a oposta da que geralmente se vê em sala de aula - é necessário chamar a atenção para esses 'erros' para que o aluno se conscientize de que ainda tem muito a aprender e, conseqüentemente, não estabilize sua interlíngua em um patamar não apropriado, apesar de aparentemente funcional para esse mesmo aluno. O ritmo do curso também precisa ser muito mais rápido, evitando-se o passo-a-passo do ensino de outras línguas para “(...) experimentar o ensino comunicativo por áreas de conhecimento (interdisciplinar)" (ALMEIDA FILHO, 2002, p. 20). Não que se tenha de ter uma metodologia específica para hispano-falantes, mas uma metodologia portadora de algumas especificidades.

Franzoni (1992) afirma que o processo de ensino/aprendizagem é uma "forma de lidar com o alheio, como um processo que envolve a entrada em contato (em conflito) com modos diferentes de constituição de sentidos" (FANZONI, 1992, p.81).

A autora vai além da definição de uso da língua para comunicar-se (instrumentalização da língua), pois acredita que essa definição é redutora demais para uma realidade tão complexa quanto o sistema lingüístico e seu aprendizado. Ela fala em conceito de função (que nos remete às abordagens funcionais), ou seja, o 'para que' da língua; em conceito de intenção (que nos remete às abordagens enunciativas) ou, mais especificamente, do esquecimento 2, citando Pêcheux, ou a ilusão de transparência do discurso; em conceito de cooperação (que nos remete ao princípio 
cooperativo); em conceito de negociação (que traz à tona a questão da disputa de sentidos e, portanto, do não-apagamento de 'desigualdades').

Em termos de processo ensino/aprendizagem, isso implica dizer que a língua é também um instrumento de comunicação, mas não somente isso. Aprender uma língua estrangeira (ou a norma padrão da língua materna) traz um eterno conflito de aproximação com o alheio, implica o controle de uma situação formal de ensino mas também o espaço para o não estrutural, para o fugidio, que também fazem parte da língua. Implica a angústia da incerteza de não se ter sua intenção clara pelo uso das novas estruturas; implica a incerteza da adequação do uso das expressões aprendidas; implica a negociação de sentidos (ou a redução das incertezas) e a cooperação (entre aluno e falantes nativos ou mais capazes do que ele), para que o aprendiz possa tornar suas, as palavras alheias e incorporar, com essas palavras alheias, tudo o que as acompanha: a cultura, as tradições, enfim, a forma de o outro (o falante da língua-alvo) conceber o mundo e lidar com ele.

Há ainda a questão dos saberes que acompanham o indivíduo que influenciam diretamente o processo de aprendizagem - não são somente esses saberes, mas a própria língua-alvo que reconfigurará a sua língua materna e a ele mesmo, num processo que nos remete a um dos princípios do Pensamento Cemplexo - o da Recursividade. O controle sobre esses saberes será maior quando professor e aluno partilham da mesma língua materna, já que o primeiro já percorreu a distância entre LM e língua-alvo; e será menor caso o professor esteja em situação endolíngüe ${ }^{13}$, (caso dos cursos de português para estrangeiros no Brasil).

\footnotetext{
${ }^{13}$ Em oposição à situação exolíngüe, quando a língua ensinada não é a mesma do país onde o aluno a aprende.
} 


\section{Livros Didáticos de Português para Estrangeiros com abordagem comunicativa}

\subsection{A Abordagem Comunicativa}

Firth (s/d), citado por Galloway (1993), tenta resumir as bases teóricas dessa abordagem que prega que a língua é interação, e que, portanto, a sua aquisição é feita nas diversas atividades interpessoais numa relação muito clara com a sociedade:

"In this light, language study has to look at the use (function) of language in context, both its linguistic context (what is uttered before and after a given piece of discourse) and its social, or situational, context (who is speaking, what their social roles are, why they have come together to speak)" (GALLOWAY, 1993, $\mathrm{s} / \mathrm{p})^{14}$

Vemos aqui uma clara relação com o Paradigma Funcional, ou seja, a preocupação em se abordar a língua de acordo com as funções em determinados contextos, não ficando somente no texto (um diálogo, uma história, por exemplo), mas levando em conta toda a situação do discurso (que inclui gestos, prosódia, os indivíduos envolvidos, quem escreve e para quem escreve, etc.).

Além disso, a idéia de que adquirimos uma língua de forma interpessoal ou interacional está totalmente de acordo com Vygotsky (1998), Demo (2002), entre outros, além de condizer com o Paradigma Complexo em vários de seus princípios.

Tan (2004) explica que as diversas atividades propostas pela abordagem comunicativa ensinam as habilidades necessárias à comunicação indiretamente, num clima natural, não ameaçador e relaxante, já que privilegia a troca de idéias entre alunos e professores.

Galloway (1993) explica ainda que essa abordagem surgiu a partir da iniciativa de diversos lingüistas que se viam insatisfeitos com as metodologias áudio-oral e 'grammar-translation'15, já que essas não preparavam o aluno para situações

\footnotetext{
${ }^{14}$ Sob esse prisma, o estudo da língua tem de objetivar o uso (função) da linguagem no contexto, tanto no contexto lingüístico (o que é inferido antes e depois de um dado discurso) quanto no contexto social ou situacional (quem fala, seus papéis sociais, por que estão juntos naquela situação de fala.

15 Áudio-Oral: conhecido como método do exército. Durante a II Gerra Mundial, o governo americano solicitou às universidades que elaborassem um método de ensino de línguas estrangeiras para treinar seu exército. O método consistia na presença em sala de um falante nativo da língua-alvo (alemão,
} 
verdadeiramente comunicativas. O grande objetivo de tal abordagem é proporcionar ao aluno oportunidades durante a aula, de envolvimento na comunicação em situações 'da vida real' na língua-alvo, ficando para o professor o papel de facilitador, ou seja, o que fala o menos possível porém dá suporte para um desempenho cada vez melhor do aluno na língua-alvo.

Puren diz o seguinte sobre a abordagem comunicativa:

Dans l'approche communicative, comme son nom l'indique bien, on passe à une 'approche par la communication' que se propose d'englober en cohérence tous les domaines. C'est la fonction du concept de 'compétence de communication', définie par sés composantes parmi lesquelles on retrouve les anciens domaines de la grammaire (dans la composante 'linguistique'), du lexique (dans la composante 'référentielle') et de la culture (dans la composante 'socioculturelle'). Cette approche par la communication emerge déjá dans la méthodologie audiovisuelle (...) (PUREN, 2004, pág. 5). ${ }^{16}$

Por outro lado, Puren defende a idéia de que nenhuma metodologia ou abordagem é totalmente acabada e adequada para todo tipo de situação, todo tipo de aluno ou todo tipo de objetivo: o autor fala em 'didática complexa' que viria substituir o ecletismo $^{17}$ empírico de professores, quando se migraria de um paradigma de otimização, feito de respostas absolutas e que considera as melhores opções metodológicas sem considerar o contexto, para um paradigma de adequação, no qual certas opções metodológicas são relevantes e eficientes em contextos específicos seria esse o pressuposto para se lidar com a complexidade do ensino/aprendizagem de uma língua estrangeira.

O autor prega o uso de uma pedagogia diferenciada (entenda-se adequada à situação, aos alunos, aos objetivos) ao lado de uma aprendizagem autônoma, na qual o professor permite que o aluno coloque em ação seus próprios métodos de

\footnotetext{
italiano, francês, chinês, etc.) usado como informante para fornecer frases-modelo a serem repetidas e aprendidas pelos alunos. Grammar-Translation: método criado no fim do século XVIII na Prússia (atual Alemanha) que consistia em adquirir conhecimentos em leitura de outras línguas estudando sua gramática para interpretar os textos, além de usar o dicionário (The Pennsylvannia State University).

${ }^{16} \mathrm{Na}$ abordagem comunicativa, como seu próprio nome bem indica, passa-se a uma 'abordagem pela comunicação' que se propõe englobar coerentemente todos os domínios. É a função do conceito de 'competência de comunicação', definida pelos seus componentes entre os quais se encontram os antigos domínios da gramática (no componente 'lingüístico'), do léxico (no componente 'referencial') e da cultura (no componente 'sócio-cultural'). Essa abordagem pela comunicação emerge já na metodologia audiovisual (...).

${ }^{17}$ Segundo Rong (s/d), na Filosofia dá-se o nome de ecletismo à escola de Potamon d'Alexandrie que recomenda emprestar o que há de melhor dos diversos sistemas (quando eles são conciliáveis), o que é preferível a criar um novo sistema.
} 
aprendizagem, estes podendo ser recursivamente influenciados ou não pela pedagogia diferenciada (PUREN, s/d a e b).

Tan (2004) reforça essa idéia de autonomia do aluno ao afirmar que na abordagem comunicativa é ele quem dirige o aprendizado diante do número de opções/oportunidades que as inúmeras atividades propostas pelo livro didático ou pelo professor oferecem e, o mais importante (vemos aqui o indivíduo ativo na construção do seu conhecimento de que nos fala o paradigma complexo), a chance de praticar a língua-alvo de acordo com o nível do aluno é muito maior do que a oferecida por outros métodos/abordagens.

A motivação do aluno é alimentada pela variedade de situações comunicativas e significativas a que é exposto, além da vontade ativa de compreender o outro, já que a ênfase durante uma aula comunicativa é a escuta e a fala.

Galloway (1993) sugere uma série de exercícios para tornar a aula (e, por que não, o livro didático) a mais comunicativa possível. Seu primeiro exemplo é a distribuição de cartões (flash cards) na língua-alvo com perguntas e respostas, fazendo que os alunos interajam entre si para encontrar a resposta do seu cartão-pergunta, por exemplo. Em seguida, um exercício de escuta que usa aquelas frases é proposto, e daí o professor pode explicar como aquelas perguntas e respostas variam na forma de acordo com as diversas situações sociais e com as escolhas individuais, trabalhando a adequação da linguagem. Por fim, alguns pontos da gramática e das estruturas utilizadas são explicados.

O outro exercício proposto pela autora é o eavesdropping (algo como ouvir a conversa alheia sem ser notado). O aluno pode, em um restaurante, por exemplo, tentar ouvir sobre o que as pessoas nas outras mesas estão conversando e, depois, responder a algumas perguntas como: quem estava conversando? Qual a idade aproximada dessas pessoas? Onde essas pessoas estavam e sobre o que conversavam? O que elas disseram? Elas perceberam que você as escutava? Durante a aula, o aluno deve reportar essa situação da vida real a toda a sala, mostrando sua opinião sobre tal situação e até provocando uma discussão entre os colegas. Exercícios como este motivam o aluno justamente porque ele tem a liberdade de escolha do tópico num nível apropriadamente desafiador. 
Outro exercício sugerido pela autora seria a escuta de situações reais (que podem vir de um tape ou da leitura em voz alta pelo professor), sempre na língua-alvo, a partir dos quais o aluno teria de escolher entre algumas opções disponíveis em seu material sobre o que tratava tal situação. Enfim, a autora defende que exercícios dessa natureza trazem muito mais elementos para uma comunicação eficiente do que exercícios de repetição ou drills (uso repetitivo da estrutura estudada), apesar de, em nenhum momento, ela defender a idéia de que tais exercícios jamais possam ser usados.

Tan (2004) aponta, por outro lado, essa falta de ênfase na gramática como uma limitação da abordagem comunicativa, ou antes, uma concepção enganosa dessa abordagem, já que, segundo essa autora, a gramática é necessária para que a comunicação aconteça de forma eficiente e para que, principalmente, não ocorram fossilizações dessa gramática (a exemplo do Singlish de Cingapura ${ }^{18}$ ).

Tan defende a idéia de o aluno precisar de muito mais que habilidades comunicativas: ele precisa ter um vocabulário extenso para poder se comunicar. Como solução, Tan defende o uso de um método pré-comunicativo para alunos mais fracos, começando por atividades mais centradas no professor, como exercícios de perguntas e respostas.

Outra limitação da abordagem, ainda segundo Tan, é que geralmente não se reconhece o papel da cultura em sala de aula. Exemplos disso são os alunos de Cingapura e do Japão que, por sua base cultural confuciana, tendem ao coletivismo (em oposição à tendência ocidental ao individualismo), a recear uma exposição maior aos colegas ('to lose face' - 'ameaça à face') e a esperar que o professor seja uma figura de autoridade. São necessários ajustes no método antes de se chegar a atividades como 'role play' ou debates, por exemplo. ${ }^{19}$

\footnotetext{
${ }^{18}$ Cingapura é um país de imigrantes asiáticos principalmente, cujos descendentes falam diversos idiomas como o chinês (mandarim e cantonês), dialetos indianos, além do inglês como segunda língua. $O$ 'Singlish' seria então um inglês que sofreu as influências dos dialetos de seus falantes.

${ }^{19}$ Segundo Rong, s/d, os chineses, por sua longa história religiosa ligada ao taoísmo e ao confucionismo que trazem sempre juntos os opostos (ying/yang; noite/dia, etc.), sentem dificuldade em responder 'sim' ou 'não' a uma pergunta, uma resposta excluindo a outra, como fazemos no ocidente: como tudo muda, tanto o universo quanto o ser humano, para um chinês um 'sim' pode levar a um 'não' e vice-versa, por isso a resposta será um 'sim E não', uma não excluindo a outra. Como nos mostra nossa própria experiência, a resposta pode ser ainda mais evasiva como um 'não é conveniente' (bu fanbian), o que geralmente significa um 'não' menos categórico.
} 
Tan recomenda que um bom curso comunicativo precisa oferecer lições que trabalhem vocabulário, funções, pronúncia e outros elementos da língua e, como atividades pré-comunicativas para alunos iniciantes, poder-se-ia começar com atividades sobre temas familiares ao aluno, como comentar problemas sociais de seu país (trabalhar-se-ia o sentimento de pertencimento do aluno), seguido de uma explicação dos elementos relevantes da língua dada pelo professor - isso exporia o aluno à língua num contexto abrangente e familiar e o levaria à retenção das diversas funções e significados antes de aprender sobre as formas gramaticais.

\subsection{A questão dos materiais autênticos}

Além de uma abordagem comunicativa, vários autores defendem o uso de materiais 'autênticos' em sala de aula (ALMEIDA FILHO,2002; TOMLINSON, 2001), para que o aluno tenha contato com a língua utilizada no 'mundo real' e possa compará-la à sua interlíngua de forma freqüente, o que aumentaria as possibilidades de aquisição da língua-alvo.

Antes, porém, cabe-nos esclarecer o que vem a ser 'material autêntico'. Franzoni (1992) fala em pelo menos três definições diferentes - a de Coste (1970): “...tudo aquilo que não foi preparado para o ensino de francês como língua estrangeira(...) aquilo que não é adaptado ou retocado (...) que não se limita a formas escritas..." (apud FRANZONI, 1992, p. 42); a de Breen (1985, apud FRANZONI, 1992), que desloca o conceito de autêntico para as tarefas realizadas pelo aluno e para a interpretação de texto que se deseja que o aluno tenha, ou seja, uma interpretação mais próxima possível da interpretação que um nativo daria a determinado texto ou enunciado; a de Porcher (1984, apud FRANZONI, 1992), que defende a inclusão do artificial em função de “...uma pedagogia da racionalidade, do afastamento do concreto imediato...' como '...mais eficiente para compreender o concreto do que uma pedagogia do pitoresco que

Por causa dessa mentalidade, ainda segundo Rong, as metodologias importadas do ocidente levam aproximadamente 20 anos para serem adotadas - são antes mais criticadas do que praticadas, e acabam sendo assimiladas pela metodologia tradicional, formando um ecletismo metodológico. 
fica colada ao concreto...' Pode-se, segundo esse autor, chegar ao natural através do artificial" (FRANZONI, 1992, p. 46).

A autora ainda comenta que, para Bresse (1980, apud FRANZONI, 1992), o termo 'autêntico' é ambíguo, já que um texto elaborado para uso específico em sala de aula também tem seu autor que atesta a origem de tal texto, portanto o 'autentifica'. Franzoni afirma que o termo autêntico, contudo, resiste e fica, até hoje, nos limites prescritos pela definição de Coste, ou seja, todo material que não foi preparado com fins específicos para o ensino de línguas.

Dessa forma, tomamos como base para o termo 'autêntico' no presente trabalho, também, o sentido de Coste (1970 apud FRANZONI, 1982) em uníssono com Tomlinson, 2001, que oferece como exemplos desse tipo de material, artigos de jornais, letras de música, romances, entrevistas no rádio, contos de fadas. Ele afirma que textos escritos para exemplificar o uso do discurso indireto, ou um diálogo escrito para exemplificar as diversas formas de convite, ou versões lingüisticamente simplificadas não poderiam ser tomados como textos autênticos, apesar de o autor não afirmar que tais textos não deveriam ser usados. Franzoni (1992) diz que nos dias de hoje é praticamente impensável a possibilidade do uso de materiais que não contenham material autêntico, tanto em sua forma gráfica (artigos, textos de outros domínios, etc.), visual (fotos, postais) ou sonora (fitas de áudio, entrevistas gravadas de estações de rádio, etc.).

Outro aspecto importante do material didático é a utilização de textos de outras disciplinas, como defendem Almeida Filho (2002) e Santos (2003) como forma de combater a tendência presente até hoje de se privilegiar a gramática nos diversos métodos de L2/LE, ou, como afirma Ferreira (1992), a necessidade de comunicação propositada deve ser prioridade na elaboração de materiais didáticos de línguas estrangeiras, já que, ainda segundo essa autora, os materiais apegados demais à gramática tradicional e aos postulados estruturalistas relegam para um segundo plano as habilidades comunicativas, além de não oferecerem ao aluno a possibilidade de manejar o conhecimento por si mesmo e inovar o próprio conhecimento.

Tan (2004) vai ainda mais longe, quando se trata de comunicação propositada e interdisciplina, ao sugerir uma abordagem temática para o ensino de línguas, ou seja, usar a língua como instrumento para ensinar outras disciplinas. 
Para Almeida Filho (2002), ao utilizar material autêntico, o professor poderia garantir que os conteúdos trabalhados estivessem mais próximos da realidade, pois mais contextualizados (poder-se-iam utilizar textos de livros de geografia ou de história referentes ao país onde se fala a L2/LE, por exemplo), projetando a atenção dos alunos para além da sala de aula, para algo que valesse a pena aprender, aprendendo, assim, a utilizar a língua como meio de comunicação eficiente e não como fim em si mesma.

Além disso, os alunos teriam acesso a material que pudessem questionar, fazer perguntas sobre ele, discordar de seus conteúdos, etc. Por ser material autêntico, esses textos permitiriam a utilização de recursos não lingüísticos como mapas, gráficos, quadros numéricos. Tanto o desempenho na língua-alvo como o conhecimento dela se beneficiariam do fato de tais textos poderem ser percebidos como uso comunicativo propositado. Ou seja, além de fatores afetivos, interacionais, culturais do aluno (conforme defende SANTOS, 2003), deve-se levar em consideração o uso de material interessante para ele na sua nova vida em convívio com a L2/LE que pretende dominar.

\subsection{O livro didático (LD)}

O livro didático, na verdade, precisa ser pensado como 'instrumento' de um objeto de estudo, um 'mediador não exclusivo', pois outros materiais avulsos podem ser usados conforme a necessidade.

Segundo Ferreira, "o que deve ser priorizado é o que se fazer, como trabalhar esse material" (FERREIRA, 1992, p.49), ou seja, ele não deve servir de programa a ser seguido rigidamente, mas um algo a mais, a parte física da língua ensinada, que precisa ser manuseado e até reutilizado futuramente, em busca de outras interpretações, outras possibilidades.

Além disso, quando se trata de material construído (manuais, livros), é necessária uma análise pré-pedagógica por parte do professor, para que ele (re)conheça os fundamentos teórico-metodológicos sobre os quais tal obra foi escrita a fim de saber o que pode exigir desse instrumento e como pode, de alguma forma, adaptá-lo ou complementá-lo. 
Quanto ao uso de materiais autênticos nos LDs, a autora aconselha a variedade de temas, e não somente textos de mídia para que o aluno possa ter acesso a linguagens mais específicas de diferentes campos.

A nosso ver, esse tipo de seleção 'eclética' ${ }^{20}$ de materiais auxilia no processo de aprendizagem no que diz respeito à adequação de códigos, já que cada campo do saber possui uma 'linguagem' própria, com suas escolhas próprias - é a autonomia da língua como sistema se manifestando, apesar de sua dependência do meio onde é utilizada.

Sobre o aspecto 'adequação', acrescentamos, ainda, a observação de Ferreira (1992) que aponta para a necessidade de inclusão de exercícios que contrastem os dois níveis de linguagem - o formal e o coloquial (ou informal), "visto que uma das marcas do falar bem uma língua é saber adequar a linguagem ao interlocutor, à situação e ao tema. É necessário sensibilizar o aprendiz para as diferentes variedades lingüísticas exemplificadas no contexto adequado a cada modalidade" (FERREIRA, 1992, p. 61).

Segundo Tomlinson (2001), para garantir a eficiência do material didático, porém, é importante que ele seja compreensível para o aluno (vemos aqui a teoria do input compreensível de Krashen (1981, apud GERMAIN, 1996)), ao mesmo tempo em que oferece desafios - não há por que utilizar longas matérias de jornais com iniciantes, mas eles podem seguir instruções, ouvir música, preencher formulários.

Se o aluno realmente deseja ser capaz de usar a língua para comunicar-se, é importante que ele seja exposto a discursos planejados (uma palestra formal, por exemplo), semi-planejados (uma entrevista informal no rádio) e não planejados (uma conversa espontânea), além de lhe serem oferecidas oportunidades de interação com o input mais do que a mera recepção passiva.

Tomlinson (2001), na verdade, oferece uma espécie de 'receita' do que os materiais para uso em sala, incluindo aí os próprios livros didáticos, deveriam oferecer

\footnotetext{
${ }^{20}$ Poderíamos também basear essa seleção de materiais no que o ecletismo metodológico prega: para adaptar-se ao seu público-alvo, a determinados objetivos e ao conteúdo a ser ensinado, ora materiais que enfocam a gramática, ora o vocabulário, ora a cultura, ora linguagens diferentes de campos diferentes de saber poderiam ser utilizados (RONG, s/d). Por outro lado, apesar de esse ecletismo ser uma boa resposta pragmática e imediata dos profissionais de ensino (professores, autores de livros didáticos) à complexidade do processo de ensino/aprendizagem, a reflexão metodológica sobre esse ecletismo não pode ser posta de lado (PUREN, s/d b).
} 
aos seus usuários. São inúmeros os itens de sua 'receita' para confecção de materiais efetivos no aprendizado de uma língua estrangeira, que, em nossa opinião, coincidem com o que o paradigma complexo prega: os materiais devem ter impacto pela novidade e variedade, além de apresentação agradável; devem fazer o aluno sentir-se confortável e não ansioso ou sob pressão; devem oferecer pequenos desafios para desenvolver a confiança do aluno; o que está sendo ensinado, deve ser percebido como relevante e útil pelo aluno, pois de alguma forma se relaciona com sua experiência pessoal, com a língua 'real', com tarefas da 'vida real' para alcançar objetivos de curto prazo agora; devem solicitar do aluno que ele faça pesquisas e descobertas por si mesmo; além da exposição a materiais autênticos (como discorremos acima), a atenção do aluno deve também ser dirigida aos aspectos lingüísticos do input; devem oferecer ao aluno oportunidades de uso da língua-alvo para alcançar propósitos comunicativos, privilegiando situações de interação (também já apontado por ALMEIDA FILHO, 2001 e por FRANZONI, 1992); os materiais precisam levar em conta que cada aluno tem um estilo diferente de aprendizado, seja visual (quando ele prefere escrever, p.ex.), auditivo (quando ele prefere ouvir), cinestésico (quando ele prefere atividades com algo físico, como seguir instruções), 'estudioso' (quando ele prefere prestar atenção aos aspectos lingüísticos e espera ser corrigido), entre outros ${ }^{21}$; devem levar em conta que os alunos diferem em atitude, e assim diversificar a linguagem de instrução baseados na variedade de estilos cognitivos ${ }^{22}$; devem maximizar o potencial de aprendizagem, encorajando o envolvimento intelectual, estético e emocional que estimulam os dois lados do cérebro; não devem confiar muito

\footnotetext{
${ }^{21}$ Os outros tipos de aprendizagem apontados por Tomlinson são: experiencial (preocupa-se muito mais com a comunicação do que com correção); analítico (prefere aprender a língua aos poucos, em pequenas partes); global (prefere lidar com grandes porções da língua de uma só vez); dependente (prefere aprender a partir do que o professor e o livro oferecem); independente (prefere aprender por meio de sua própria experiência e usar estratégias autônomas de aprendizado). $\mathrm{O}$ autor ainda esclarece que o tipo de aprendizagem escolhido pelo aluno depende sempre da língua que ele aprende, de seus objetivos, das circunstâncias do aprendizado.

${ }^{22}$ Os estilos cognitivos dizem respeito a formas particulares de se comportar em determinadas situações. Geralmente são considerados parte da dimensão da personalidade que influencia atitudes, valores e interação social. Para conseguir atingir o maior número de estilos cognitivos, segundo Tomlinson (2001), o material didático precisa oferecer opções de diferentes textos, de diferentes tipos de atividades, exercícios extras para os mais motivados, providenciar variedade, providenciar atividades que convidem o aluno a discutir suas atitudes e seus sentimentos sobre o curso e sobre o material, levar em conta os interesses do público-alvo do LD, estar consciente das sensibilidades culturais desse público, orientar o professor em manual específico sobre como lidar com alunos não participativos.
} 
na prática controlada, já que ela, segundo o autor, parece ter pouco efeito a longo prazo na acuidade com que os novos inputs são usados, além de ter pouco efeito sobre a fluência; devem oferecer oportunidades de feedback quanto à produção do aluno, porém voltado mais para a efetividade do que para a acuidade dessa produção, já que os objetivos da comunicação (conseguir o que se quer pela língua por meio da adequação do discurso, da prosódia, como visto no paradigma funcional) devem ser mais importantes do que a mera prática da língua (não que a prática das estruturas não seja importante, como nos lembra TAN, 2004).

Tomlinson (2001) reconhece, porém, que não há uma fórmula fixa nem uma visão única que funcione para conduzir o processo de ensino/aprendizagem como um todo, que não existe uma teoria predeterminada que seja 'a' teoria correta no que diz respeito às pesquisas em aquisição lingüística.

\section{4. $O$ aluno jovem ou adulto}

É exatamente esse questionamento que o Pensamento Complexo traz de novo para o campo do ensino de línguas: não há uma teoria final e única, uma teoria correta que exclui as demais, uma abordagem única que substitui todas as outras anteriores a ela. E isso se aplica tanto ao ensino para crianças como para jovens e adultos, estes público-alvo dos LDs analisados a partir do capítulo seis do presente trabalho.

Se nos lembrarmos, porém, do que Vygotsky (MARXISTS, s/d) prega sobre a memória extremamente mediada do adulto, para o qual lembrar significa pensar (formase um link temporário por combinação artificial de estímulos), já que o uso de símbolos leva o ser humano a criar novas formas de um processo biológico baseado na cultura, e nos lembrarmos das palavras de van Passel, (1983, apud KUNZENDORFF, 1997) sobre a importância da compreensão, da lógica, do 'para quê', do fazer sentido para que o adulto consiga aprender, da importância da adequação da metodologia aos objetivos do aluno e ao seu nível de conhecimento lingüístico e cultural, além de se conhecer como funciona a língua materna dele, teremos, com certeza, boas pistas de 
como um livro didático deve apresentar seus conteúdos e de quais conteúdos apresentar.

Além desses autores, outros como Krashen et al (1982), defendem uma certa superioridade cognitiva do aluno adulto em relação à criança, principalmente nos estágios iniciais e especialmente no aprendizado da sintaxe e da morfologia, já que o aluno adulto geralmente tem a capacidade de ter pensamentos abstratos, ou seja, a capacidade de ter idéias sobre idéias.

Isso significa que o aluno adulto (a partir da adolescência) emprega técnicas conscientes para aprender e, portanto, muitas vezes são alunos melhores do que as crianças, além de serem mais rápidos também.

Krashen, porém, reconhece que o aprendizado consciente é apenas uma parte no caminho da aquisição de uma L2/LE, sendo boa parte deste caminho subconsciente - a habilidade de aprender uma língua conscientemente ajuda nos estágios iniciais, mas pode até atrapalhar nos estágios mais avançados. Daí a necessidade de se trabalhar no aluno a tendência de procurar sentidos dentro de um contexto na línguaalvo, e não somente traduzir, por exemplo, como forma de aprendizado.

Por outro lado, é necessário trabalhar também a tendência de criar estratégias e hipóteses, a tendência de se ter atitudes positivas em relação à nova língua e à nova cultura que almeja conhecer e dominar.

É o próprio Pensamento Complexo que nos traz a noção do sujeito como um estrategista (como citado anteriormente), que formula e testa suas teorias durante o longo percurso de sua busca pelo conhecimento, este sempre inacabado. Apesar disso, os porquês de se enfocar determinado conteúdo e não outros precisam estar muito claros no livro didático, além de uma sólida ancoragem na cultura que está por trás da língua ensinada (a cultura também é citada por Santos (2003) como forma de superação do sentimento de não-pertencimento).

Van Passel (1983) faz um resumo bastante elucidativo do que seria lidar com esse público. Segundo esse autor, "os adultos, em geral, se propõem a adquirir num mínimo de tempo o máximo de conhecimentos num âmbito bem determinado. $E$ é precisamente para essa tarefa que nem o ensino nem os professores se encontram preparados" (VAN PASSEL, 1983, p. 28). Devido a motivos profissionais, diplomáticos ou outros que trazem o sentimento de urgência em aprender, esses alunos tendem a 
frustrar-se com os métodos adotados durante o seu curso, especialmente quando não são dirigidos à sua área de interesse.

Caberia aqui, ainda segundo van Passel, um trabalho de conscientização desse aluno, pois todos os campos têm uma língua básica comum e que precisa ser aprendida em primeiro lugar, apesar de nada impedir que alguns termos do campo de interesse do aluno possam ser ensinados, pois isso lhe traz a sensação de já estar aprendendo o vocabulário de que necessita.

Um outro problema apontado por van Passel é o fato de o adulto escrever prematuramente: o autor defende que há uma ordem para a aquisição - primeiro vem a compreensão auditiva, porque o recurso imediato à escrita comporta um grande perigo para a aprendizagem da forma falada da língua-alvo.

Ainda outro problema, ou 'vício' como van Passel prefere chamar, é o da lista de palavras, que leva o aluno ao hábito de 'traduzir' tudo e ao erro conseqüente de pensar que as orações são somente palavras isoladas enfileiradas.

Além disso, outros fatores precisam ser levados em conta pelo professor (e pelo autor do livro didático), como a fadiga após um longo dia de trabalho (o material precisa transmitir leveza para que o aluno possa relaxar em aula), além de problemas psicológicos causados pela presença de subordinados no mesmo grupo, por exemplo.

Van Passel também aponta um grande erro dos livros didáticos, que via de regra não definem as metas de aprendizagem, o que traz o sentimento de frustração para o aluno:

"nada é mais frustrador nem desencorajador que a ignorância a esse respeito, que a impossibilidade de saber o que se pode fazer com os conhecimentos adquiridos, de determinar em que momento do curso as necessidades pessoais estarão satisfeitas" (VAN PASSEL, 1993, p. 34).

Um curso elementar, por exemplo, deveria deixar claro que dará ao aluno a possibilidade de acompanhar e entender uma conversação entre um nativo e um estrangeiro, de manter um diálogo com um nativo sobre assuntos corriqueiros, etc.

Além disso, ligado ao fator 'objetivo', está o fator 'tempo' que, segundo o autor, deve ficar em torno de 200 horas para o curso elementar, já que ainda não existe fórmula miraculosa de se aprender em tempo menor, idéia tão difundida pela mídia e, muitas vezes, presente na mente dos alunos adultos. 
É claro que no quesito tempo, van Passel provavelmente fala de línguas que não o espanhol, já que o aprendizado do português por hispano-falantes, por exemplo, seria bem mais rápido.

Como última observação, o autor defende a idéia de que o material didático é somente um meio, um auxiliar, e que a sua leitura até o fim não garante a aquisição (como defende também FRANZONI, 1992): "o número de horas de participação efetiva tem uma importância infinitamente superior ao número de páginas lidas" (VAN PASSEL, 1983, p. 35).

Além disso, por causa da urgência que o aluno adulto geralmente sente em aprender uma nova língua, ele acaba reclamando algumas regras, exigência no sentido de obter um enfoque racional da língua-alvo. Uma forma de satisfazer essa exigência, segundo o autor, seria o uso de esquemas de substituição de termos em frasesmodelo, o que, a despeito de se defender a abordagem comunicativa para ensino de línguas, acreditamos, pode funcionar para esclarecer alguns aspectos lingüísticos a serem enfocados. Van Passel conclui seu raciocínio defendendo a idéia de que

"quanto mais desfavoráveis forem as circunstâncias em que ocorre a aprendizagem de uma língua estrangeira (fadiga, problemas psicológicos, exigências a serem satisfeitas), melhores e mais poderosos devem ser os recursos didáticos empregados para se chegar ao resultado desejado" (VAN PASSEL, 1983, p.38). 


\section{Metodologia}

\section{Algumas perguntas que resumem a base teórica vista até aqui}

Vamos tentar resumir toda a base teórica do Pensamento Complexo e teorias afins apresentadas neste trabalho, sob a forma de perguntas ou quesitos a serem observados durante nossa análise do corpus.

Em seguida, faremos a análise sob a luz desses quesitos de como os quatro livros didáticos de português para estrangeiros introduzem e sedimentam os verbos 'ser' e 'ter', cada um em um capítulo à parte (capítulo seis - o 'ser' como verbo de ligação e como auxiliar na passiva; capítulo sete - o 'ter' como verbo principal e como auxiliar nos tempos compostos).

Ao mesmo tempo em que descrevemos os procedimentos utilizados para introduzir os verbos 'ser' e 'ter' pelos autores dos LDs de nosso corpus, ofereceremos sugestões de como tais verbos poderiam ser mais bem trabalhados para que esses LDs ficassem mais próximos de nossa base teórica, sugestões essas baseadas no que o Pensamento Complexo e teorias afins oferecem, além de outras advindas de nossa experiência de oito anos em sala de aula.

Por fim, no capítulo oito, descreveremos como esses verbos são introduzidos pela série New Interchange de ensino do inglês a título de sugestão complementar.

Esclarecemos que não analisamos todos os tempos verbais de 'ser' e 'ter' em nosso corpus, mas somente aqueles em que tais verbos demonstrariam mais problemas ora pelo uso ora pela forma irregular. Para facilitar a leitura, procuramos destacar os nomes dos tempos abordados em negrito.

Seguem, então, as perguntas ou quesitos a serem observados em nossa análise:

1) Contextualização - De acordo com o Princípio Sistêmico ou Organizacional, a aquisição da língua como conhecimento é tratada de forma rotativa, ou seja, ela vai da parte para o todo e do todo para a parte? Do objeto para o indivíduo e do indivíduo para o objeto? Da sociedade para o sujeito e do sujeito para a sociedade? Em outras palavras, existe uma real preocupação em 
contextualizar as estruturas ensinadas para que esse movimento rotativo ocorra e para que, assim, aconteça a aprendizagem significativa?

2) Cultura do aluno e troca de papéis aluno/professor - De acordo com o Princípio Hologramático (o todo está nas partes assim como as partes estão no todo), a forma de expor o aluno às estruturas enfocadas, para elegermos um dos muitos aspectos passíveis de aplicação desse princípio, considera a cultura desse aluno e a insere de alguma forma nas atividades propostas além de facilitar a troca de papéis entre professor e aluno (conforme DEMO, 2002; ALMEIDA FILHO, 2002, ou seja, o aluno tem a oportunidade de trazer elementos novos à sala de aula para participar da construção do seu conhecimento ativamente, pois ao assumir também o papel de emissor se encontrará em situações de comunicação real)?

3) Relevância do que é ensinado - De acordo com os Princípios de Retroatividade e de Recursividade (o efeito ou o produto reage sobre a causa, o que é aprendido reage sobre aprendizagens anteriores, modificando-as e incorporando-as), o que é ensinado é percebido como relevante pelo aluno, pois de alguma forma relaciona-se com a sua experiência pessoal e com a língua 'real' e tarefas da vida 'real' (TOMLINSON, 2001), além de ser retomado no decorrer das unidades do LD (a construção do conhecimento não é linear, mas cheio de idas e vindas)?

4) Atividades mais indutivas que dedutivas - De acordo com o princípio de reintrodução do sujeito (não há conhecimento neutro nem passível de transmissão, há sempre um sujeito que constrói o seu próprio conhecimento), o LD facilita a construção do conhecimento da língua-alvo por meio de atividades muito mais indutivas (de usos específicos para as regras) do que dedutivas (partindo das regras ou esquemas para os usos específicos, segundo FERREIRA, 1992)?

5) Pequenos desafios - De acordo com o Princípio da Dependência das Condições Iniciais, o LD considera o conhecimento prévio do aluno e oferece pequenos desafios para provocar a 'emergência de aprendizagem' (a teoria do input compreensível de Krashen, apud MENEZES, s/d e GERMAIN, 1996)? 
6) Adequação ao nível do aluno - O LD oferece atividades nas quais o aluno pode utilizar seus conhecimentos prévios, adequando a atividade ao seu nível (GALLOWAY, 1993)?

7) Situações-problema - O LD oferece atividades que criam situações para que o aluno resolva ativamente 'problemas' do cotidiano, assim desenvolvendo suas habilidades comunicativas (Vygotsky (1989, apud DELGADO, 2003 e NEVES, 1997)?

8) Aquisição por meio da interação social - Ainda de acordo com o Princípio da Recursividade, a aquisição da L2/LE é tratada como produto e causa das interações sociais, ou seja, o outro é tratado com a devida importância?

9) Variedade - Há oferta de atividades contextualizadas e de naturezas diferentes para uma visão do todo e das partes (MORIN, 1996) ao mesmo tempo em que se procura atingir os diferentes estilos cognitivos (TOMLINSON, 2001)?

10) Material autêntico / outras dimensões do indivíduo - Existe oferta variada de material autêntico (no sentido de Coste (1970, apud FRANZONI, 1992)) e de outras disciplinas para suprir a necessidade de comunicação propositada (TAN, 2004; SANTOS, 2003; ALMEIDA FILHO, 2002), levando em conta as outras dimensões do indivíduo como a poética, ética, histórica, social, cultural, corporal, emocional e subjetiva (SANTOS, 2003; MENEZES, s/d), além de levar em conta que pensar/sentir/atuar são uma unidade integrada, uma levando à outra (SANTOS, 2003)?

11) Distância entre Língua Materna e Língua-Alvo - São trabalhados de alguma forma os atratores estranhos (MENEZES, s/d) como os interesses do aluno e a proximidade ou distância entre língua materna e língua-alvo (ALMEIDA FILHO, 2001)?

12) Adequação de registros - É levada em consideração a adequação de códigos ou de registros (FERREIRA, 1992; NEVES, 2004), visto que uma das marcas de se falar bem uma língua é saber adequar a linguagem ao interlocutor, à situação e ao tema? 
13) Visual atraente - A forma de apresentação da conjugação verbal é visualmente atraente (com muito espaço em branco, fotos, cores atraentes, de acordo com TOMLINSON, 2001)?

14) Adequação ao público-alvo - A apresentação dos verbos 'ser' e 'ter', assim como o LD como um todo, é realmente adequada ao seu público-alvo (jovens e adultos), ou seja, leva em conta a fadiga, a necessidade de algumas regras práticas, além de apresentar metas claramente definidas (VAN PASSEL, 1983)?

15) Ampliação vocabular e aspectos lingüísticos - Há oferta de oportunidades para a ampliação vocabular além de se enfocarem aspectos lingüísticos relevantes (TAN, 2004)?

As palavras-chave a serem consideradas em nossa análise são: contextualização - centralização no aluno - oportunidades de interação - atividades percebidas como relevantes - processo de construção do próprio conhecimento. 


\section{Análise do corpus - verbo 'ser'}

A reflexão crítica sobre a prática se torna uma exigência da relação Teoria/Prática sem a qual a teoria pode ir virando um blábláblá e a prática, ativismo."

(PAULO FREIRE, 1996, p.22)

\subsection{Introdução do verbo 'ser'}

Como define Garcia, 2001,

"o verbo ser é o principal verbo designativo do português. Ele é o que mais perfeitamente satisfaz os critérios de classificação, pois além de não aceitar voz passiva, aceitar qualquer tipo de sujeito, ter uma colocação praticamente ilimitada, ter um caráter aspectual estativo (permanente) tão marcado que não aceita (em seu uso normal) o aspecto progressivo e poder ser usado em três diferentes predicações ${ }^{23}$, e não ter efetivamente nenhum sinônimo, ele é o verbo equativo por excelência, devido ao fato de uma relação de igualdade pressupor sempre uma relação de permanência" (GARCIA, 2001, s/p).

O termo 'designativo' para classificar o verbo 'ser' aparece, segundo o autor, para melhor definir vários verbos injustamente classificados como verbos de ligação, pois não são vazios de significado como os definem as gramáticas tradicionais.

Dessa forma, talvez por ser um verbo designativo por excelência, como o define Garcia (2001), ou talvez por ser um dos verbos mais utilizados em nossa língua, especialmente por sua qualidade 'equativa' (eu sou João; ela é Maria), logo provavelmente utilizado no início de qualquer relacionamento humano para apresentações, as obras de nosso corpus apresentam esse verbo sempre na primeira unidade, ou seja, é o primeiro verbo com o qual o aluno estrangeiro toma contato formalmente. Vejamos, então, como os livros didáticos analisados pelo presente trabalho, apresentam esse verbo.

No Falar...Ler...Escrever... a apresentação e sedimentação do verbo 'ser' no Presente do Indicativo é feita como todos os demais verbos com que essas autoras trabalham: a obra introduz a conjugação verbal por meio de diálogos situacionais e, em seguida, uma tabela com a conjugação do verbo enfocado e exercícios estruturais para

${ }^{23}$ 1) A predicação equativa: eu sou britânico; 2) A predicação locativa temporal e espacial: o baile é hoje/aqui; 3) A predicação atributiva: eu sou feliz. 
utilizar tal verbo. Depois disso, entram pequenos textos também situacionais e, em unidades posteriores, textos sobre a história ou a cultura brasileiras, com exercícios de interpretação.

A unidade 1 do livro do aluno inicia com três diálogos de apresentação (situacionais), com largo uso do 'ser', reproduzidos a seguir, com os verbos sublinhados:

Diálogo 1 - Como vai?

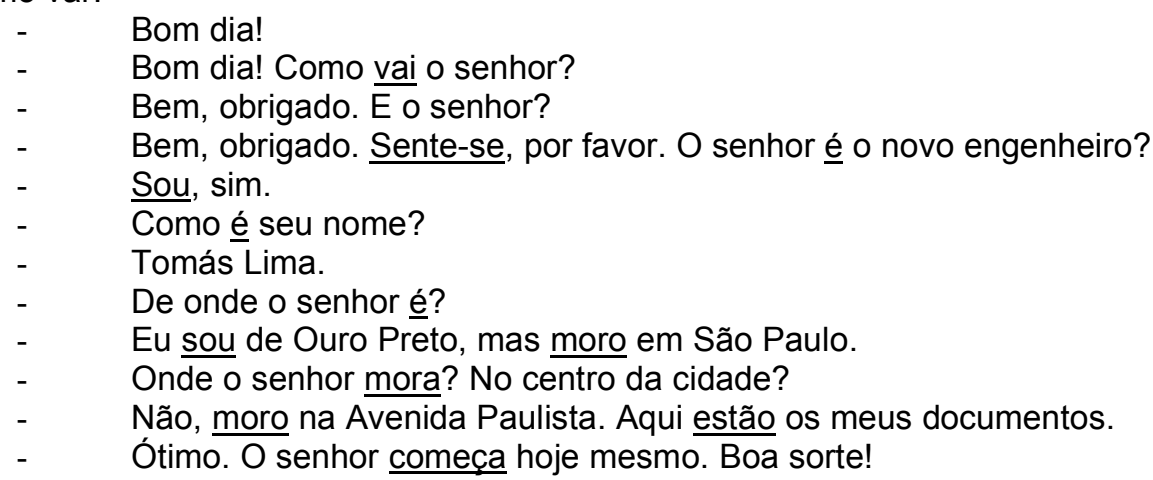

Diálogo 2 - Você é de São Paulo?

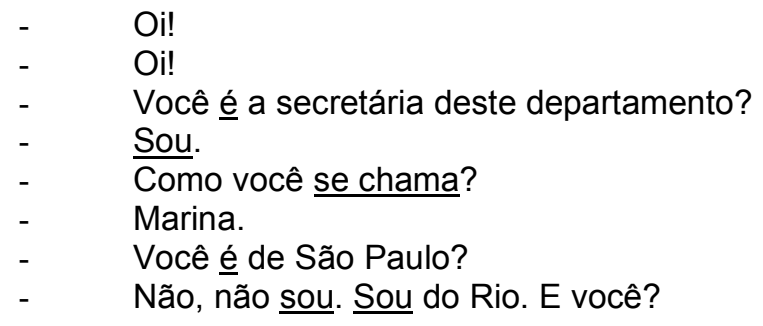

Diálogo 3 - Muito prazer
Diretor:
Seu Oliveira, este é Tomás Lima, o novo engenheiro.
Sr. Oliveira:
Muito prazer.
Tomás Lima:
Muito prazer.

Sem considerar o título de cada diálogo, houve a ocorrência de 19 verbos conjugados, em sua maioria na primeira e na terceira pessoas do singular (eu; você as palavras mais dêiticas da língua, segundo COSTA, 2002), sendo dessas aproximadamente $58 \%$ dedicadas à conjugação do verbo 'ser', $22 \%$ à de verbos regulares da primeira conjugação (morar, começar), além do verbo reflexivo 'chamar-se' (uma ocorrência) e do verbo 'estar' (uma só ocorrência também). Portanto fica fácil concluir que o enfoque aqui é o verbo irregular 'ser' na primeira e na terceira pessoas do singular. 
Por outro lado, deparamo-nos com um pequeno problema já nesta unidade inicial do Falar...Ler...Escrever...: é o fato de dois verbos irregulares, o 'ser' e o 'estar', serem introduzidos tão proximamente, numa mesma unidade (mais adiante, uma tabela de conjugação desses dois verbos, além de exercícios estruturais, estão à disposição do aluno), cuja distinção é, segundo van de Wiel (2001), sempre um ponto crítico independentemente da metodologia. Como todos os livros analisados têm jovens e adultos como público-alvo, falantes de qualquer idioma, ficamos em dúvida quanto à clareza dessa forma de introduzir verbos que, em diversas línguas, não são 'separáveis' como em português, a exemplo do inglês (am/is/are), do alemão (bin/bist/sind/seid), ou de uma língua oriental, como o chinês, que possui uma só forma verbal para todas as pessoas - 'shi', equivalente a 'ser' - e utiliza uma preposição de lugar (zai) como equivalente ao nosso 'estar' (wo zai Baxi - eu (estou) no Brasil).

A dificuldade de compreensão da diferença entre ser/estar seria bem semelhante à dificuldade que nós, brasileiros, temos para compreender a diferença entre make/do do inglês ou entre tun/machen do alemão (todos 'fazer' em português). Já o espanhol faz essa diferenciação entre ser/estar (soy/eres/es/somos/sois/son e estoy/estás/estamos/estais/están), portanto, apesar de haver pequenas exceções (a preferência do verbo 'ser' ou 'ficar' para localizações em português, e do verbo 'estar' para o mesmo fim em espanhol, por exemplo), as dificuldades para hispano-falantes perante esses diálogos, a nosso ver, seriam mínimas. Além disso, existe um exercício na unidade 3 que trabalha essa diferença entre ser/estar, apesar de fazê-lo ainda de maneira bastante superficial.

Um aspecto interessante da unidade 1 de Falar...Ler...Escrever... é a introdução simultânea ao verbo 'ser' dos verbos regulares da primeira conjugação, o que abre muito o leque de possibilidades de trabalho com os alunos e, portanto, de oportunidades de uso da língua-alvo.

Outro aspecto interessante da obra fica por conta do livro de exercícios (vendido separadamente) que privilegia a escuta e oferece exercícios de compreensão na atividade de escuta inicial de cada unidade, tanto em forma de perguntas quanto em forma de lacunas a preencher, além de trabalhar já um pouco de regência verbal (morar em, gostar de) de forma bastante 'leve', seja por respostas de múltipla escolha para perguntas orais gravadas no cassete (vendido separadamente) que acompanha o livro 
de exercícios, seja pelo preenchimento de lacunas. O último exercício na unidade 1 desse livro é de escrita, o qual solicita que o aluno escreva um texto sobre uma das personagens do exercício de escuta inicial.

A introdução do verbo 'ser' por um diálogo situacional já na unidade 1 do livro do aluno - uma situação de apresentação, no caso - é bastante positiva, pois coerente com a visão funcional da língua. Poder-se-ia aproveitar essa oportunidade para trabalhar com cartões (os flash cards sugeridos por GALLOWAY, 1993) ou com um exercício de pôr as frases dos diálogos em ordem (elas viriam fora de ordem nessa atividade inicial), e, em seguida, ler os diálogos para os alunos ou passá-los no cassete (disponível para venda separadamente) para checagem da pronúncia e reforço do uso das estruturas. Além disso, poderia haver fotos de personalidades de diversos países ou de diversas profissões que deveriam ser associadas às suas respectivas origens ou ocupações - abrir-se-ia aqui uma grande oportunidade de uso dos outros pronomes pessoais (ele, ela, eles, elas, nós), além de se trabalhar um pouco mais a idéia de que o verbo 'ser' associa-se a origem e a profissão (também, é claro, a estado civil, localização, estados mais permanentes, etc.).

Existe ainda na unidade 1 do livro do aluno um exercício de perguntas e respostas que trabalha a idéia de origem no qual as expressões mais formais de tratamento são utilizadas (o senhor / a senhora), apesar de ter o objetivo de treinar a fusão da preposição 'de' com os artigos definidos. Há ainda neste exercício algumas pequenas figuras humanas vestidas com trajes típicos de alguns países, como Espanha (um toureiro), Alemanha ou Áustria (um tirolês), Japão (uma mulher usando quimono), Groelândia (um esquimó) e Havaí (uma havaiana) que, apesar de não terem suas correlações nas perguntas do exercício que ilustram, podem ser utilizadas pelo professor para reforçar a idéia 'ser + origem'.

Como o título do exercício traz a pergunta 'de onde o senhor é?', uma atividade mais interativa poderia ser proposta aqui por meio de uma pesquisa a ser feita pelo aluno para descobrir a origem de cada colega e do professor (especificar-se-iam as cidades ou até o bairro) para reportar à sala mais tarde. Além disso, o livro didático poderia propor nomes de personalidades conhecidas (Pelé e Paulo Coelho, Schumacher, Rainha Elizabeth II e Príncipe Charles, Julia Roberts, etc.) a serem 
usados em uma atividade em duplas a fim de treinar tanto a conjugação do verbo 'ser' quanto o uso da pergunta 'de onde... é?'.

A separação entre 'ser' e 'estar' como verbos que trazem a idéia de estado permanente ou mais duradouro versus estado transitório, respectivamente, fica um pouco mais clara na unidade 3 do Falar...Ler...Escrever... quando uma rápida explicação é oferecida no topo da página, reproduzida a seguir:

\begin{tabular}{|l|l|}
\hline Quadro 3 & Diferença entre 'ser' e 'estar' no Falar...Ler...Escrever... \\
\hline Ser ---- qualidade permanente & Estar---- qualidade temporária \\
Ela é bonita. & Ela está bonita hoje. \\
O Saara é quente. & Hoje está quente. \\
\hline
\end{tabular}

A esse quadro explicativo seguem frases soltas para preenchimento de lacunas para que o aluno opte entre 'ser' e 'estar', além de uma última explicação sobre usos especiais de 'ser' para idéia de posse, de tempo cronológico, de profissão, de cargo, de religião, de partido político, de expressões impessoais. O aluno deve optar entre os dois verbos enfocados em duas atividades mais adiante, além de conjugar o verbo escolhido corretamente.

Sugeriríamos, aqui, uma atividade muito utilizada no método comunicativo (de acordo com GALLOWAY, 1993) em que o aluno entrevista um ou dois colegas para descobrir um pouco mais sobre ele/eles e reportar suas descobertas para a sala. As próprias perguntas das atividades anteriores poderiam ser utilizadas (você é garçom? / você é inglês? / você é chefe? / você está com fome? / vocês estão com sono?), a que o aluno entrevistado provavelmente responderia 'não, sou americano', por exemplo. Essa é uma forma simples de promover a intensa negociação de sentidos de que nos fala Germain (1996).

No Avenida Brasil 1, a separação entre ser/estar é bem mais clara do que no Falar...Ler...Escrever..., pois sua unidade 1 começa com diálogos situacionais (de apresentação) sem usar o verbo 'estar', preferindo introduzi-lo somente na unidade 3. Reproduzimos tais diálogos a seguir, também com os verbos sublinhados:

Diálogo 1 - Como é seu nome?

Bom dia.

Bom dia.

Como é seu nome? 
Meu nome é Charles.

Diálogo 2 - Como se escreve?

E como o senhor se chama?

Eu me chamo Peter Watzlawik.

Como?

Peter Watzlawik.

Como se escreve o seu sobrenome?

W-A-T-Z-L-A-W-I-K. E a senhora, como se chama?

Diálogo 3 - O senhor é...?

O senhor é americano?

Sou sim. E a senhora, é alemã?

Não, não sou, sou holandesa.

Diálogo 4 - Qual é a sua profissão?

Qual é a sua profissão?

Sou jornalista. Trabalho no Jornal do Brasil.

Onde o senhor mora?

Moro na França, em Paris.

Mais uma vez o número de conjugações do verbo 'ser' nos diálogos representa a maioria de $56,25 \%$ contra $37,5 \%$ de verbos regulares da primeira conjugação (incluindo-se aí o reflexivo 'chamar-se') e de 6,25\% para o verbo 'escrever' (uma ocorrência).

Depois dos diálogos, há uma tabela com a conjugação do verbo 'ser' para eu /você/ o senhor/ a senhora /ele /ela /nós /vocês / os senhores/ as senhoras/eles/elas e exercícios de pergunta/resposta e de preenchimento de lacunas com esse verbo. Os verbos regulares da primeira conjugação - morar, estudar, trabalhar - vêm em um exercício que os associa a lugar (países, cidades e locais públicos), seguidos de uma pequena introdução do imperativo com os comandos utilizados no livro ('complete', 'responda', 'faça uma pergunta', etc.), de um exercício de escuta relacionado a números de telefone e, por fim, de um pequeno texto sobre o cineasta Roman Polanski. Como esse último texto trata de uma atividade que enfoca o vocabulário sobre cinema, talvez os autores tenham se permitido utilizar o Pretérito Perfeito (!), inclusive de verbos irregulares como 'vir' e 'ser', a título de sensibilização do aluno para tal tempo.

Pensamos, porém, que em uma primeira unidade que enfoca o verbo 'ser' e verbos regulares da primeira conjugação no Presente do Indicativo, esse tipo de sensibilização estaria um tanto fora de hora, especialmente porque o Pretérito Perfeito só será trabalhado quatro unidades mais adiante. 
Destacamos, contudo, a inclusão já no início da unidade das expressões 'o senhor' e 'a senhora' como forma de tratamento respeitosa e mais formal (fato também no Falar...Ler...Escrever...), o que atende, de certa maneira, à necessidade de se ensinar antes esta modalidade já que, segundo Kunzendorff (1997), a passagem da linguagem mais formal para a informal ou coloquial é muito mais simples do que o contrário.

Existe uma certa abertura na obra para trabalhar esses níveis de linguagem, já que há quadrinhos ilustrativos nos diálogos nos quais se lêem cumprimentos formais (até logo) e informais (tchau). Por outro lado, os exercícios ainda são compostos de frases soltas, descontextualizadas, apesar de geralmente relacionadas ao tema da unidade.

Verificamos também esse tipo de exercício mais estrutural no livro de exercícios, porém notamos lá a preocupação de se introduzirem materiais autênticos (na concepção de COSTE, 1970, apud FRANZONI, 1982 ${ }^{24}$ ) como fotos, formulários a serem preenchidos com nome, profissão, etc., além de uma atividade descritiva sobre uma terceira pessoa, e de um exercício de escuta (uma entrevista no rádio) no qual o aluno deve preencher um cartão de identificação com todos os dados do entrevistado.

De forma geral, o Avenida Brasil 1 apresenta sua primeira unidade de maneira bastante conforme com a abordagem comunicativa de que se diz porta-voz. Uma sugestão para melhorar a forma de como o verbo 'ser' foi introduzido e explorado seria fazer com que os alunos levantassem de suas cadeiras para entrevistar os colegas, tendo de preencher fichas de identificação com os dados desses colegas (ou sobre o professor) como feito no exercício de escuta, por exemplo, e apresentar suas descobertas para a sala toda no final da atividade, além de associações com adjetivos (inteligente, elegante, simpático, etc. e antônimos) em perguntas de opinião sobre pessoas famosas, incluídas na mesma entrevista aos colegas (TOMLINSON, 2001, quanto à importância dos pequenos desafios ; GERMAIN, 1996, quanto à intensa negociação de sentidos; TAN, 2003, quanto à importância do vocabulário mais amplo).

Outra possibilidade de exercício entre colegas (ou aluno e professor) é o de perguntas fechadas (cujas respostas são 'sim' e 'não'), na qual o professor, por

\footnotetext{
${ }^{24}$ Todo material produzido sem o fim específico de uso no ensino da língua, como artigos, contos, textos de outros campos do saber, etc.
} 
exemplo, pensa em um artista ou em um político (algumas fotos e alguns dados de tais pessoas poderiam estar disponíveis no próprio LD), e os alunos fazem perguntas para descobrir de quem se trata, como 'É homem?'; 'É brasileiro?', 'É cantor?’; etc. a fim de obter respostas como 'É'; 'Não é'.

Enfim, há muitas formas de se usar o verbo 'ser' nos mais diversos contextos para que uma melhor fixação ocorra, encorajando o maior envolvimento intelectual, estético e emocional de que nos fala Santos (2003), com o objetivo de gravar aquela informação (o uso do verbo 'ser', no caso) no maior número de lugares do cérebro (de acordo com TOMLINSON, 2001).

No Fala Brasil a introdução da conjugação verbal de 'ser' no Presente do Indicativo acontece também na primeira unidade, porém em um segundo diálogo (ou pequenos diálogos) na página 8 , intitulado (e reproduzido a seguir) 'Identificar - Identify - Identifier' (traduções para o inglês e o francês que acontecem principalmente no título de cada diálogo situacional e nos comandos dos exercícios nesta obra):

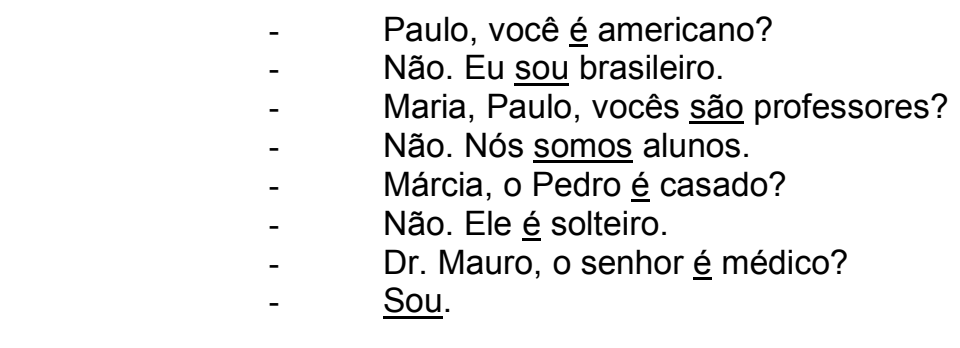

E nos balões dos quadrinhos juntos aos diálogos:

Dona Maria, a senhora é casada?

Sou. Esse é César, meu marido.

Muito prazer.

O prazer é todo meu.

Desnecessário dizer que todas as entradas privilegiam a conjugação verbal de 'ser' nas mais diversas situações a que vem associado: profissão, nacionalidade, estado civil, apresentação de terceiros ('Esse é César') e em expressões ('O prazer é todo meu').

Esses pequenos diálogos abrem as mais diversas possibilidades de se oferecerem ao aluno situações reais em que o verbo 'ser' é utilizado, situações essas exploradas nos exercícios seguintes, mesmo que de frases soltas para preenchimento de lacunas, além de uma leitura de expansão (em forma de quadrinhos) na qual o verbo 
'ser' é utilizado com o pronome 'qual' em perguntas como 'qual (é) o seu nome?', 'qual (é) o sobrenome dela?', etc.

No caderno de exercícios (vendido separadamente), a forma escolhida para sedimentação do uso desse verbo é o preenchimento de lacunas em diversos microdiálogos e exercícios de ligar palavras de colunas diferentes (nossa casa - é - cara).

O fato de todas as obras de nosso corpus utilizarem diálogos na introdução do verbo 'ser' é, em princípio, bastante positivo, pois de certa forma contextualiza o uso de tal verbo em situações muito próximas às da 'vida real', o que vai ao encontro do que pregam o pensamento complexo e o paradigma funcional (contextualizar para relacionar as partes com o todo e o todo com as partes).

Faltam ao Fala Brasil, porém, exercícios mais interacionais para que oportunidades de comunicação 'real' aconteçam entre os próprios alunos ou entre o professor e o aluno, como, por exemplo, uma pequena entrevista para exposição posterior aos colegas, ou um exercício de perguntas e respostas, sendo que um aluno teria as perguntas e outro teria as informações necessárias para responder a tais perguntas. ${ }^{25}$ Aspectos intelectuais e emocionais (TOMLINSON, 2001; SANTOS, 2003 ${ }^{26}$ ) poderiam ser abordados com perguntas simples que poderiam ser feitas durante as atividades interacionais, como: o Brasil é um país interessante?; Caetano Veloso é um cantor talentoso?; A secretária da escola é eficiente?; O seu país é grande?; etc.

Além disso, notamos a falta de material autêntico na unidade: há apenas algumas tirinhas para a sedimentação da conjugação verbal.

Por outro lado, há no Fala Brasil uma comparação entre 'ser' e 'estar' na página 32 que, a nosso ver, demonstra-se bastante completa, já que vem em forma de um quadro comparativo com as diversas situações em que tais verbos são usados no espaço (indica localização permanente ou móvel), no tempo (indica o momento), para pessoas e coisas ('ser' identifica tudo o que não muda, 'estar' indica o estado provisório de alguém ou de algo), concluindo que "SER é absoluto. ESTAR é relativo" (Fala Brasil, p.32).

\footnotetext{
${ }^{25}$ Conforme sugere Germain (1996), sobre tarefas interacionais convergentes, preferíveis ao debate (tarefa interacional divergente) no que concerne ao número de questões levantadas pelos estudantes, ao número de questões de ordem referencial, ao número de pedidos de confirmação.

${ }^{26}$ Sobre a necessidade de maximizar o potencial de aprendizagem ao encorajar o envolvimento intelectual, estético e emocional do aluno, estimulando os dois lados de seu cérebro.
} 
A comparação entre os dois verbos continua na página seguinte em forma de duas colunas comparativas com frases e algumas perguntas e respostas usando os dois verbos, porém não se propõe nenhuma atividade para utilizá-los.

Sugerimos, então, um exercício com uso de material autêntico, de inclusão desses verbos em frases descritivas junto a uma foto com diversos objetos, como: verde, quadrada e sobre o sofá' para o aluno apontar na figura a localização da almofada; comprido, preto e dentro do estojo' para um lápis; ‘ sobre a mesa, redondo e de vidro' para um cinzeiro, já apontando a associação do verbo 'ser' com materiais (é de vidro, é de madeira, etc.), e assim por diante.

Esse tipo de exercício poderia ser usado com fotos de pessoas ou de profissionais, de um guarda-roupa, de um banco, sempre contextualizado no tema a ser trabalhado na unidade. Além disso, rostos com expressões diferentes poderiam ser usados (ele está contente; ela está triste; etc.) ou de associação com os advérbios 'sempre', 'jamais, 'nunca', etc. para pequenas situações oferecidas pelo livro (Maria uma boa professora, mas nunca contente com seus alunos). Um exercício mais interativo seria possível com mapas nos quais os alunos, em duplas ou em pequenos grupos (conforme sugere GERMAIN, 1996, para que a intensa negociação de sentidos ocorra), poderiam tentar descobrir determinadas localizações, quando se treinariam perguntas como: 'onde está a escola?' ou 'onde está a Avenida Rebouças no mapa?'; etc.

A introdução do verbo 'ser' no Bem-Vindo! também é feita no Presente do Indicativo, porém de maneira bem peculiar já na primeira unidade - ele vem com outros verbos irregulares, o 'estar' e o 'ter'. Como dito acima, para hispano-falantes provavelmente não haveria grandes problemas, e, além disso, a introdução desses verbos é feita em forma de um texto que apresenta uma família (há inclusive o uso de material autêntico por meio de uma foto dessa família ao lado do texto), mas para falantes de outros idiomas que não o espanhol, provavelmente haveria dificuldades logo de início. 
O verbo 'ser' vem mais sedimentado em um dos exercícios posteriores que usa fotos de personalidades brasileiras (Xuxa, Pelé, Milton Nascimento), mas ainda misturando 'ser' com os outros dois verbos citados ('estar' e 'ter').

Um ponto positivo da obra é a tentativa de contextualização: além de fotos, existe a preocupação de se utilizarem pequenos textos para introduzir a conjugação verbal, e da proposição de exercícios mais interativos, como uma entrevista a ser feita com os colegas ou o professor.

De forma geral, a conjugação do 'ser' é bem introduzida e de acordo com o paradigma complexo e teorias afins ao longo de todo o Bem-Vindo!, pois bem contextualizada em diversos textos situacionais, além do enfoque no oral. Porém, se levarmos em consideração alunos falantes de outras línguas que não o espanhol (e talvez o francês e o italiano), tal apresentação traz problemas ao oferecer um input muito acima do compreensível (segundo KRASHEN, 1982, também citado por GERMAIN, 1996, sobre a teoria do input compreensível).

Como o método oferece cadernos separados para falantes de origem latina, anglo-saxônica e asiática, vejamos, então, como a conjugação de todos os verbos introduzidos na unidade 1 são sedimentados nos dois cadernos voltados a falantes de línguas que não o espanhol.

No caderno voltado a falantes de origem anglo-saxônica, oferecem-se exercícios com todos esses verbos misturados, com exceção de um - o da árvore genealógica (Marcos e Bete são marido e mulher; Rosa é filha de Marcos e Bete; etc.), no qual utiliza-se exclusivamente o verbo 'ser'. A maioria dos exercícios apresenta-se em forma de preenchimento de lacunas, e a utilização de denominações gramaticais é bastante grande (complete com os verbos..., complete com os adjetivos...).

Apesar de não serem atividades de repetição, são bastante estruturalistas, com exceção de um único exercício que apresenta um quadro com algumas informações sobre uma pessoa, e o aluno precisa fazer perguntas sobre essa pessoa utilizando os pronomes interrogativos.

Mesmo o caderno de exercícios voltado a falantes de origem asiática não apresenta forma muito melhor que o anterior (a maioria dos exercícios é de preenchimento de lacunas), além de trazer todos os verbos misturados. Existe também um exercício que trabalha a árvore genealógica a partir de um texto no qual os verbos 
'ser', 'ter' e 'estar' foram omitidos, devendo ser preenchidos pelo aluno. A unidade oferece também dicas culturais, como as formas de os brasileiros cumprimentarem-se formal ou informalmente.

Os dois cadernos de exercícios procuram trabalhar os aspectos estruturais da língua, mas acabam utilizando frases soltas e descontextualizadas em quase todos os exercícios (há também alguns poucos textos pequenos para preenchimento de lacunas), o que contradiz a pretensão comunicativa do método (apesar de TAN, 2004, chamar a atenção para a necessidade de exercícios de gramática para compensar as limitações do método comunicativo).

Como vimos em Tomlinson (2001), o livro didático deve enfocar aspectos gramaticais e estruturais, especialmente quando comparados à língua-materna do aluno, como forma de facilitação da aquisição, mas não de maneira dedutiva ou como enfoque principal da obra - trata-se de uma complementação necessária já que a língua também é gramática, porém contextualizada e posterior a outras atividades interativo-comunicativas (nesse ponto, a obra analisada está coerente com a visão de Tomlinson, já que os exercícios mais estruturais viriam depois dos interacionais do livro do aluno).

Além disso, o material apresentado precisa fazer sentido para o aluno e, para fazer sentido, a contextualização (em textos, fotos, esquemas) e o conhecimento dos interesses desse aluno, além da sua língua materna, são essenciais. Do nosso ponto de vista, o enfoque no aluno não acontece de maneira satisfatória nos livros de exercícios do Bem-Vindo!, justamente pela pouca contextualização e porque a língua desse aluno em contraste com o português é pouco considerada.

Por outro lado, a introdução de elementos culturais nessa obra é louvável (como os brasileiros cumprimentam-se, por exemplo), apesar de feita de forma um tanto inadequada, já que fora de contexto (vem dentro de um quadro, como uma dica, e não é trabalhada em seguida), além do uso excessivo de cores e de vários tópicos diferentes em uma mesma página, poluição visual que torna a apresentação da obra um tanto confusa, especialmente pela falta de espaços em branco, espaços esses que, segundo Tomlinson (2001), atrairiam mais a atenção do aluno-leitor. 
Por ser um verbo irregular também no Presente do Subjuntivo, o 'ser' é introduzido no Falar...Ler...Escrever... na unidade 13, junto dos outros seis verbos irregulares nesse tempo (estar, haver, dar, saber, ir e querer). A apresentação da forma do 'ser' é feita por uma expressão que denota dúvida ${ }^{27}$ : 'Duvido que ele seja um bom funcionário', seguida das expressões impessoais que introduzem o subjuntivo (é possível que, é provável que, é necessário que, basta que, preciso de alguém que, etc.), além de uma tabela com as conjunções que introduzem esse modo (para que, embora, contanto que, a não ser que, mesmo que, caso, sem que, até que, antes que, a fim de que, desde que) e de um exemplo com palavra indefinida + pronome relativo: ‘Estou procurando uma secretária que... possa viajar / saiba inglês / seja simpática.

A sedimentação de 'ser' e dos demais verbos no Presente do Subjuntivo é feita por meio de diversos exercícios de preenchimento de lacuna em forma de frases soltas, além de outro com duas colunas para que o aluno faça ligação entre elas e forme frases, e de uma atividade situacional em que o aluno deve imaginar-se conversando com um corretor de imóveis e explicando como deve ser a casa que ele quer comprar ('Eu quero uma casa grande, embora minha família seja pequena'; 'É importante que a sala seja grande', etc.).

No Avenida Brasil, o 'ser' no Presente do Subjuntivo é introduzido na penúltima unidade do livro 1 por meio de uma tabela em que aparecem conjugados na primeira pessoa do singular, todos os sete verbos irregulares nesse tempo apontados acima. $O$ aluno é convidado a preencher a conjugação das demais pessoas (você, ele, ela, nós, vocês, eles, elas) nessa mesma tabela. Alguns desses verbos são usados em um exercício em forma de colunas em que o aluno precisa fazer escolhas de cada coluna para formar frases.

$\mathrm{Na}$ verdade, esses verbos irregulares são introduzidos depois de que os regulares foram conjugados em tabelas e apareceram em textos ou em atividades interativas. Uma das atividades envolvendo os verbos irregulares sugere que o aluno converse com o colega sobre suas opções de diversão nas férias ('Para onde você vai nas férias?' - 'Ainda não decidi, talvez vá para...'), seguida de diversos recortes de anúncios de jornais que oferecem pacotes turísticos.

\footnotetext{
${ }^{27}$ As expressões que exigem o uso do Subjuntivo são introduzidas na unidade 12 (verbos de desejo, de ordem, de dúvida e de sentimento), além da própria forma dos verbos regulares nesse tempo/modo.
} 
Cabe destacar que no início da unidade que introduz o Presente do Subjuntivo há várias fotos de localidades turísticas no Brasil, como Foz do Iguaçu, o Pantanal, Ilha de Marajó, entre outras. Seguem-se diálogos-exemplo do uso do subjuntivo que utilizam as fotos como contexto.

O Bem-Vindo! Introduz o Presente do Subjunto por meio de um texto em que um professor solicita de seus alunos uma pequena redação sobre a imagem que os alunos têm do Brasil. Os verbos que exigem o subjuntivo (de desejo, de ordem, etc.) são introduzidos no texto e retomados na atividade seguinte que pede ao aluno que discuta com o colega os detalhes de uma possível viagem à Europa. Os verbos ou expressões que exigem o subjuntivo, vêm grafados seguidos de reticências sugerindo que o aluno as complete (Espero que..., Tomara que..., etc.).

Outras situações são sugeridas para que o aluno conjugue os verbos no subjuntivo ('Espero que eles cheguem a tempo no hospital. Tomara que não seja nada grave'.), quando o 'ser' é finalmente introduzido, de maneira indutiva, como nas demais atividades deste LD.

Por outro lado, chama-nos a atenção o fato de o Futuro do Subjuntivo também ser introduzido nessa mesma unidade, o que iria de encontro à teoria do input compreensível de Krashen, já que traz informações em demasia: de acordo com nossa experiência, o presente deveria ser utilizado em muitas outras oportunidades antes da introdução de qualquer outro tempo verbal, especialmente para falantes de outras línguas que não o espanhol.

No Fala Brasil, o 'ser' no Presente do Subjuntivo é introduzido por meio de uma tabela de conjugação na qual aparecem os sete verbos irregulares nesse tempo (SER seja, seja, sejamos, sejam; ESTAR - esteja, esteja, estejamos, estejam, etc.), seguida de uma rápida explicação sobre o uso do subjuntivo (para julgamento, eventualidade, dúvida: 'Retire do cesto do cesto as laranjas que estejam podres' em comparação ao mesmo tempo no Indicativo: 'Retire do cesto as laranjas que estão podres'), além de oferecer uma pequena lista de verbos e expressões que trazem a idéia de dúvida, sentimento, desejo, vontade, pedido, ordem, que exigem o uso do subjuntivo. 
Essa rápida explicação condiz com o que Krashen (1982) aponta sobre a necessidade dos adultos de dispor de regras práticas, de entender o porquê da escolha do subjuntivo no lugar do indicativo.

Tal explicação, por outro lado, é seguida de uma atividade de preenchimento de lacunas em forma de pequenos diálogos, os 'diálogos dirigidos', muito utilizados pelos autores, mas que não dão muita abertura à interação com os colegas.

Sugerimos então explorar um pouco mais as atividades propostas pelos LDs de nosso corpus - a conversa com um corretor de imóveis, por exemplo, poderia ser usada como dramatização, quando um aluno faz o papel do profissional, e o colega, o do comprador que busca a casa dos sonhos. Ou ainda a sugestão do Avenida Brasil sobre programa de férias, poderia ser usado para o mesmo fim.

Outra sugestão seria a entrevista: um dos alunos faz perguntas que já podem estar sugeridas no livro sobre o que os colegas esperam do curso de português (que ele seja mais dinâmico, que ofereça mais oportunidades de interação com nativos por meio de passeios), por exemplo - boa oportunidade de trazer expectativas à tona e talvez até reformular alguns pontos do curso. Os resultados seriam discutidos em sala e compilados pelo professor ou por um dos alunos no quadro para futuras cobranças, o que tornaria a atividade de sala mais próxima do 'real'.

\subsection{O Pretérito Perfeito e o Imperfeito do Indicativo de 'ser' e de 'ter'}

Van de Wiel (2001) é quem aponta a diferença entre Pretérito Perfeito e Imperfeito dos verbos em português como a principal fonte de problemas na aquisição dessa língua por falantes de línguas que não fazem essa diferenciação, como o inglês e o alemão, mesmo porque, segundo esse autor, não existe uma diferenciação clara entre esses dois tempos nos livros didáticos de português como L1, exceto algumas definições como a que Cunha (1983), citado por van de Wiel, oferece:

“(...) o pretérito imperfeito 'designa fundamentalmente um fato passado, mas não concluído (imperfeito = não perfeito, inacabado). Encerra, pois, a idéia de continuidade, de duração do processo verbal mais acentuada do que nos outros pretéritos, razão por que se presta especialmente para descrições e narrações de acontecimentos passados'" (VAN DE WIEL, 2001, p. 60). 
Por essas razões, decidimos explorar em um item à parte como os autores de nosso corpus introduzem tanto a forma quanto o uso de 'ser' e de 'ter' nesses dois tempos tão problemáticos para alunos estrangeiros. Segundo nossa própria experiência, muitas das dúvidas, especialmente quanto ao uso de tais tempos, acompanham a maioria dos alunos até estágios mais avançados do curso.

Iniciaremos com a descrição de como nosso corpus introduz e sedimenta o Pretérito Perfeito para, em seguida, observar como ele introduz o Pretérito Imperfeito do Indicativo por dois motivos: os livros didáticos analisados o fazem nessa ordem também, ambos 'ser' e 'ter' geralmente ao mesmo tempo; acreditamos que ao dominar o Pretérito Perfeito, cuja noção de ação acabada é mais marcada, teremos maiores chances de tornar explícito o que, para nós falantes nativos do Português, é implícito quanto ao uso do Pretérito Imperfeito, o qual, em muitos casos, não traz essa noção de ação acabada.

\subsubsection{O Pretérito Perfeito do Indicativo}

O Pretérito Perfeito de 'ser' é introduzido no Falar...Ler...Escrever... na unidade 5 sob a forma de um quadro de conjugação próximo a outro quadro onde se conjuga o verbo 'ir' no mesmo tempo verbal, com a intenção clara de mostrar que ambos os verbos apresentam formas idênticas no pretérito (eu fui uma boa aluna / eu fui a São Paulo), além dos verbos 'estar' e 'ter', esses apenas similares em sua forma pretérita (eu estive em São Paulo / eu tive problemas).

A preocupação das autoras em apresentar simultaneamente verbos irregulares com formas idênticas ou semelhantes em determinado tempo verbal, responde bem ao quesito 'regras práticas' citado por van Passel (1983), que aponta a busca de tais regras pelo público-alvo a que se destinam os livros analisados pelo presente trabalho: jovens e adultos.

Esses quadros são seguidos por exercícios de preenchimento de lacunas, um para cada verbo, além de um exercício final em que 'ser', 'ir', 'estar' e 'ter' são as opções de preenchimento no Pretérito Perfeito a serem usadas conforme o sentido da frase. Ainda na mesma unidade 5 , as autoras introduzem as horas na forma de frases- 
modelo ao lado de horários em algarismos arábicos a exemplo de relógios digitais (8:15 São oito e quinze), fazendo o aluno responder a diversos 'que horas são' sob o desenho de relógios analógicos que marcam as diferentes horas do dia. As demais atividades propostas para o uso das horas do dia enfocam outros verbos que não o 'ser', além de sugerir ao aluno que escreva as horas por extenso.

Sugeriríamos aqui o uso de tabelas diferentes de horários de vôos ou de saídas de ônibus da rodoviária, em que, em duplas, cada aluno perguntaria ao outro os horários de saída ou de chegada que faltam em sua tabela (somente o outro tem essas informações), como sugere Germain $(1996)^{28}$, com perguntas como 'quando o vôo xyz chega ao aeroporto, que horas são?', a que o colega responderia 'É uma e meia', por exemplo. Ou, ainda, para sedimentar um pouco mais o uso dos pretéritos, perguntasexemplo como 'quando o vôo xyz chegou ao aeroporto, que horas eram?' seriam muito bem-vindas, especialmente porque, já a essa altura do curso, sensibilizariam o aluno para o uso de 'ser' nas terceiras pessoas do pretérito imperfeito.

No Avenida Brasil 1, o Pretérito Perfeito de 'ser' é introduzido de forma similar à do Falar...Ler...Escrever... - tabelas de conjugação umas próximas às outras com o pretérito de 'ser' e 'ir' (aliás, uma mesma tabela para ambos), 'ter', 'estar' e 'fazer', na lição 6 da obra. Tal lição começa com dois pequenos textos narrados em primeira pessoa, nos quais duas mulheres contam sobre sua rotina, com uma atividade de escuta a seguir, em que cada uma delas fala de seu dia de ontem - praticamente todos os verbos são usados no passado. Seguem outras atividades a serem feitas pelo aluno, além das tabelas de conjugação e exercícios de formar frases utilizando os verbos apresentados nas tabelas.

Não vemos oportunidades de interação nessas atividades, portanto sugerimos pelo menos uma em forma de conversa com o colega, na qual cada aluno tentaria descobrir o máximo possível de informações sobre o dia de ontem (ou o fim de semana passado, ou o ano passado) desse colega - o resultado da atividade seria reportado à sala.

Outra possibilidade seria ter uma ficha de pesquisa com perguntas como 'descubra quem... foi ao clube ontem; foi um bom aluno; já foi assaltado; esteve no

\footnotetext{
${ }^{28}$ Tarefa interacional convergente em contraste com o debate, tarefa interacional divergente.
} 
museu domingo; já foi contemplado por um bilhete sorteado'; 'já foi um office boy', 'já teve catapora', entre outras, sempre de acordo com o tema da lição. Cada aluno circularia pela sala fazendo a pesquisa para comentá-la mais tarde.

Para fechar tal atividade treinando todas as habilidades comunicativas, uma pequena redação poderia ser pedida a cada aluno para que contasse sobre o resultado de suas pesquisas com suas impressões a respeito dos dados, ou mesmo sobre como foi o dia de ontem do colega - tal texto poderia ser lido em sala para comentários do professor e dos colegas, gerando novos inputs a partir da própria produção do aluno.

Uma outra sugestão de atividade a ser feita em casa para leitura e comentários em sala em uma próxima aula, seria contar a vida de algum personagem ilustre do País do aluno (George Washington foi um grande presidente americano...) - abrir-se-ia aqui a possibilidade de envolver as outras nuances do aluno, mais especificamente a sua cultura, como sugere Santos (2003).

No Bem-Vindo!, a introdução do Pretérito Perfeito dos verbos regulares e de vários irregulares acontece na unidade 2 - as tabelas com os verbos conjugados encontram-se, como de praxe, na última página da unidade.

O pretérito de 'ser' é introduzido por meio de uma entrevista com o objetivo de testar a memória do colega entrevistado, cujo título é 'será que seu colega tem boa memória?", o que dá ensejo ao uso do verbo 'ser' na expressão 'será que' indicando dúvida ou possibilidade.

Algumas das perguntas sugeridas são: 'quem foi a primeira pessoa que você cumprimentou hoje?', 'qual foi o último presente que você deu a alguém?'. Aparentemente, as duplas mudam em seguida para que a terceira pessoa (ele, ela) possa ser treinada com perguntas como 'qual foi a primeira pessoa que João cumprimentou hoje?'; 'o que Maria comeu no almoço do último domingo?'. Desnecessário dizer que a forma de se introduzir o verbo 'ser' no Pretérito Perfeito não poderia ser mais feliz, pois é feita interativamente (aspecto condizente com as teorias sobre aprendizagem de Vygotsky (1991), além dos paradigmas complexo e funconal).

Apesar de a conjugação no Pretérito Perfeito não ter sido vista antes de tal atividade, a forma desse verbo é adquirida durante a interação, quando o aluno precisa 'resolver' um problema de comunicação, como sugerido por Neves (1997). Fica, porém, 
a dúvida se em uma unidade tão no início do livro didático, a introdução de tantos verbos irregulares simultaneamente não seria input demais para falantes de línguas que não o espanhol (conforme KRASHEN, 1982, também citado por GERMAIN, 1996, sobre a teoria do input compreensível).

\subsubsection{O Pretérito Imperfeito do Indicativo}

O Pretérito Imperfeito do Indicativo de 'ser' é introduzido no Falar...Ler...Escrever... como usual, na forma de diálogos situacionais no início da unidade 8 , seguidos por um quadro de conjugação, ao lado de outros quadros de conjugação dos verbos regulares em -AR, -ER e -IR, e dos irregulares 'ter' e 'pôr'. Tais quadros são seguidos de exercícios com frases soltas a serem preenchidas com verbos sugeridos entre parênteses, além de uma história em quadrinhos no presente que deve ser passada para o Pretérito, utilizando ora o Perfeito ora o Imperfeito, de acordo com a situação e sem grandes explicações sobre o uso adequado de um e de outro tempo.

Antes de comentarmos essa última atividade do Falar...Ler...Escrever..., gostaríamos de ressaltar o que van de Wiel (2001) tem a dizer sobre a aquisição da conjugação verbal. Segundo esse autor, existe uma grande dificuldade por parte do aluno estrangeiro de aquisição das formas verbais do português, dos tempos e modos variados de verbos regulares e irregulares, além das flexões de pessoa, de número, da concordância com suas regras gerais e seus múltiplos casos especiais. Se a aquisição da forma, por si tarefa bastante árdua (adquirida pela interação social ou pela 'decoreba' mesmo), ocorre de maneira satisfatória, o seu uso ou função é a parte mais penosa para muitos alunos.

Alguns dos vários usos do Pretérito Imperfeito são apontados por van de Wiel (2001), sempre em comparação ao Pretérito Perfeito, ou sejam: como pano de fundo para uma ação passada ('la pelo caminho solitário, quando viu um estranho ser' em contraste ao uso do Past Progressive em inglês 'He was lonely going down the path, when he caught sight of a strange being'), como noção de hábito ('Estudava naquele colégio quando pequeno', em paralelo à versão em inglês 'he used to study at that school as a child'), como substituto do Futuro do Pretérito do Indicativo na linguagem mais informal ('Se tivéssemos dinheiro, comprávamos (compraríamos) esta casa' em 
contraste com o inglês 'If we had the money, we would buy this house') ou em expressões como 'eu queria' ou 'você podia', em vez de 'eu quereria' (!), 'você poderia', formas que, em inglês, vêm no condicional.

Ilari (2001) também aponta o aprendizado do Pretérito Imperfeito como uma das principais dificuldades no ensino do português para falantes de línguas como o inglês, já que esta não possui forma diferenciada para esse tempo verbal.

O autor afirma que uma seqüência de sentenças no Perfeito do Indicativo é normalmente interpretada como fazendo referência a fatos sucessivos, mas já uma seqüência de sentenças no Imperfeito do Indicativo em uma narrativa é normalmente interpretada como indicativo de que o momento de referência é o mesmo para todas, o que produz um efeito de descrição, pois indica uma espécie de 'tempo estático'. O perfeito traz o sentido de pontualização; o imperfeito traz o sentido de realçar os valores propriamente durativos: "...usando o imperfeito, sugere-se que o estado de coisas descrito pelo predicado tem limites abertos, podendo prolongar-se além do período de tempo visado do adjunto; usando-se o perfeito sugere-se o contrário" (ILARI, 2001, p. 44).

Leiria (1994), classifica o Pretérito Perfeito como Perfectivo (não traz noção de aspecto, ou de duração interna, exceto em suas perífrases como 'tenho estudado') já que, segundo a autora, ele possui o traço acabado, indicando fatos completos, em oposição ao Imperfeito que pode ser tanto Perfectivo (quando traz a noção de hábito ou de iteração) quanto Imperfectivo (com noção de aspecto, ou de duração interna, já que quanto ao traço /+ acabado/, ele é não marcado - ele nada diz respeito de o fato verbal ser referido como acabado ou não) quando expressa um fato singular, caso das suas demais nuances que não expressam habitualidade.

A autora acredita que os verbos estativos são os que mais têm relação com esse tempo ('Camões era cego de um olho'; 'Essa propriedade pertencia a meu avô'), relação também possível com verbos de ação, apesar de sua forma oscilar entre simples ou perifrástica, dependendo do contexto e do tipo de texto ('o anjo dormia' ou 'o anjo estava dormindo'): "No entanto, a forma perifrástica com o Imperfeito funciona em oposição à forma simples quando se trata de exprimir processo cursivo único ('João estava comendo') ou quando trata de processo cursivo complexo (iterativo ou habitual: 'João comia torradas no café da manhã')' (LEIRIA, 1994, p. 99). 
A autora afirma que o Pretérito Perfeito é a coluna vertebral de uma narrativa (o primeiro plano) enquanto que o Imperfeito cuida das descrições e dos comentários: "um enunciado no Perfeito basta-se a si próprio, mas um enunciado no Imperfeito pede mais qualquer coisa" (LEIRIA, 1994, p. 99).

Resumidamente, poderíamos fazer os seguintes contrastes entre Pretérito Perfeito e Imperfeito: o primeiro traz a noção de ação acabada, o segundo não traz essa noção claramente; o Perfeito representa o primeiro plano de ação, o Imperfeito, o pano de fundo; o Perfeito narra, o Imperfeito descreve; o Imperfeito pode indicar ações simultâneas no passado ('enquanto ela falava, eu escrevia'); o Perfeito poderia ser comparado a uma foto da ação ('ele falou'; 'ele foi presidente da companhia') ou, como afirma Ilari (2001), o Perfeito pontualiza, enquanto que o Imperfeito lembra um filme ('ele falava'; 'ele era' - o imperfeito realça os valores propriamente durativos, ainda segundo ILARI, 2001); o Imperfeito é geralmente usado para a narração de fábulas e lendas ('era uma vez...').

Além disso, o Imperfeito indica fatos habituais ou rotineiros no passado, podendo ser associado a expressões como 'antigamente', 'naquela época', 'quando eu era criança', enfim, estratégias outras utilizadas pelos falantes nativos para indicar o uso desse tempo.

Leiria (1994) aponta ainda o contraste entre o Português e as línguas anglosaxônicas e asiáticas, já que essas últimas não possuem uma forma diferenciada para Perfeito e Imperfeito, preferindo, especialmente o chinês, usar de outras estratégias (as partículas 'le' e 'quo') para dar a idéia de Imperfecção no passado.

De nosso corpus, o Fala Brasil oferece uma explicação concisa e esclarecedora das diferenças entre Perfeito e Imperfeito do Indicativo em sua unidade 8. Tal explicação, em forma de quadros, vem reproduzida a seguir: 

Quadro 4
"Observe os exemplos e compare:
1. Ele sempre acordava tarde.
2. Quando ele era criança, ele morava no Japão.
3. Ele era um bom menino e escovava os dentes todos os dias.
4. Maria fumava muito.
5. Sabe, eu era escoteiro quando morava em São Paulo.

A partir dessas frases, podemos dizer que:

1. O IMPERFEITO é como um filme no passado.

2. O IMPERFEITO é um espaço de tempo no passado.

3. O IMPERFEITO é um hábito no passado.

4. No IMPERFEITO você não percebe claramente o fim da ação.

5. No IMPERFEITO há um envolvimento maior com o passado.
Naquele dia ele acordou cedo.

Ele morou no Japão dez anos.

Mas... no dia 25 de fevereiro, ele não escovou os dentes.

Maria ficou grávida e fumou seu último cigarro ontem.

Mais alguém nessa classe já foi escoteiro?

\footnotetext{
O PERFEITO é como uma fotografia do passado.

O PERFEITO é usado para expressar tempo delimitado no passado.

O PERFEITO é um ponto no passado.

No PERFEITO você percebe claramente o

fim da ação.

No PERFEITO a informação é mais objetiva.
}

Apesar de todos esses contrastes, ainda há casos onde você pode encontrar dificuldades, principalmente com os verbos: estar, ser, ter.

Exemplos: ontem eu estava com dor de cabeça; ontem eu fui a uma festa. A casa era linda!; Ontem não tinha ninguém no clube (ou havia)." (Fala Brasil: 121)

É exatamente nesse contraste entre os dois tempos pretéritos que o Falar...Ler...Escrever... peca em seu exercício para passar frases de uma história em quadrinhos do Presente do Indicativo para o Pretérito Perfeito ou Imperfeito: as autoras aparentemente partem do pressuposto de que após os exercícios de treino da forma, o uso ficaria claro para se resolver um exercício em que as duas formas aparecem. Tal contraste é retomado em algumas lendas oferecidas pela obra somente na unidade 9 ('No princípio, era só o dia...'; 'Naia era uma indiazinha bem bonita...').

Uma boa oportunidade de se abordar as outras nuances e a própria cultura de origem do aluno (como apontam MENEZES, s/d e SANTOS, 2003, sobre o sentimento de pertencimento), ao mesmo tempo em que se treina a forma e o uso de verbos nos dois pretéritos, seria sugerir que o aluno trouxesse histórias ou lendas de seu país.

Júdice (2001) oferece-nos um ótimo exemplo de atividade comparativa entre culturas, nas quais o aluno traz a sua cultura para a língua-alvo, partindo da idéia de que "língua e cultura estão profundamente vinculadas, e a cultura brasileira, de muitas 
faces, favorece a aproximação e o diálogo com outras culturas do mundo" (JÚDICE, 2001, p. 65).

A atividade descrita pela autora parte da noção de que o ato básico da fala é contar. Assim, durante as aulas a alunos estrangeiros coordenadas pela autora, contavam-se ou liam-se histórias ou lendas de nossa cultura e pedia-se que os alunos tentassem encontrar em suas respectivas culturas histórias similares (uma das histórias escolhidas foi 'lara, a mãe d'água') e as contassem em sala, além de reproduzi-las por escrito.

Nesse ponto, Júdice fala da necessidade de ser compreendido que acabava promovendo "ajustes na fala de cada um e a forma ia se definindo em função do uso. A língua-alvo ia se construindo discursivamente, a partir de trocas pessoais e culturais" (JÚDICE, 2001, p. 70).

Por valorizar os conhecimentos anteriores do aluno e levar em conta seu nível de maturidade, esse tipo de atividade (que não necessariamente precisa utilizar lendas, mas biografias de pessoas famosas no país do aluno ou mesmo a história pessoal desse aluno de quando era criança, por exemplo) acaba configurando positivamente seu filtro afetivo, além de oferecer a alunos e professores a oportunidade de interação como interlocutores reais, deixando a relação aluno/professor em uma base muito mais simétrica (como defendem DEMO, 2002 e ALMEIDA FILHO, 2002, sobre a troca de papéis aluno-professor), portanto mais favorável à construção do conhecimento da língua-alvo. Ao mesmo tempo em que o aluno tenta resolver o 'problema' da comunicação (de acordo com NEVES, 1997) ao tentar adaptar-se ao nível de seu interlocutor em uma intensa negociação de sentidos (conforme GERMAIN, 1996), provoca a emergência da aprendizagem descrita por Menezes (s/d).

No Avenida Brasil 1, o Pretérito Imperfeito de 'ser' e 'ter' é introduzido na lição 8 por meio de uma tabela de conjugação para verbos regulares e dois irregulares, com mérito para uma pequena explicação sobre quais verbos são irregulares nesse tempo, porque responde bem ao quesito 'regras práticas' sugeridas por van Passel (1983): "há 4 verbos de forma irregular. Você já conhece 2 deles: ser e ter. Os outros 2, vir e pôr, você vai aprender na Lição 9" (Avenida Brasil 1, p. 79). 
Um pouco antes das tabelas, há uma ilustração que fala da vida da mulher antigamente. As frases dessa ilustração usam do advérbio de tempo 'antigamente' para descrever fatos do cotidiano feminino tempos atrás, como 'antigamente era melhor! A mulher ficava em casa e cuidava só da família' em contraste com a idéia de que hoje ela sofre muita pressão, tanto no trabalho quanto em casa; 'Antigamente era melhor: a mulher tinha mais tempo' em contraste com a idéia de que hoje ela tem dupla jornada no trabalho e em casa; 'antigamente a mulher era mais feliz' em contraste com a idéia de que hoje a mulher precisa competir com homens e outras mulheres.

Há ainda uma pergunta feita ao aluno com uma resposta padrão para descobrir sua opinião sobre o assunto: 'O que você acha disso? - Eu não concordo. Acho que antigamente a vida da mulher era mais difícil. A mulher trabalhava...'. Tal pergunta demonstra o esforço dos autores para trazer a realidade do aluno para a sala de aula, suas idéias, sua cultura, e talvez provocar um pequeno debate em sala utilizando as novas estruturas.

Logo depois de tal atividade, há outra em forma de duas colunas em que o aluno precisa ligar inícios de frases com seus finais para falar sobre rotinas no passado ('quando eu era criança, passava as férias na fazenda').

Outra função do Pretérito Imperfeito muito bem ilustrada pela obra é a de descrição no passado com o seguinte texto:

"Ele entrou na sala. As janelas estavam fechadas e a sala estava escura. O silêncio era total. Ele abriu o cofre. Estava vazio. O dinheiro não estava mais lá. Ele chamou a polícia". (Avenida Brasil, p. 80)

Tal texto é seguido por uma atividade que sugere ao aluno trabalhar com um colega, respondendo a perguntas que a polícia faria no caso de um interrogatório pela morte de um vizinho ('você viu alguém?'; 'onde você estava?'; 'o que você estava fazendo?', 'como era o seu vizinho', etc.).

Essa atividade mais interativa é seguida por outra que fala do uso do pretérito imperfeito para duas ações no passado ('quando eu cheguei, ela estava telefonando'), na qual o aluno precisa preencher lacunas com frases soltas para treinar mais esse uso do imperfeito.

Ainda outra função do Imperfeito aparece a seguir, a de duas ações simultâneas no passado, com duas setas horizontais paralelas de mesmo comprimento: sob a 
primeira lê-se 'ela cuidava das crianças' e sobre a outra 'ele lavava os pratos', sendo que o advérbio 'enquanto' vem escrito entre as duas frases.

A próxima atividade vem em três colunas com verbos e complementos a serem usados para fazer frases no tempo enfocado. Por fim, sob o tema 'fale sobre suas últimas férias', duas colunas aparecem com verbos e complementos para que o aluno os conjugue no pretérito perfeito (primeira coluna) e no imperfeito (segunda coluna): ir para / fazer calor - quando fui para o litoral, fazia calor, ilustrando ainda a idéia de descrição no passado e duas ações simultâneas também no passado, sendo uma pontual e a outra descritiva.

A partir de tal atividade, sugeriríamos que o aluno fizesse perguntas ao colega sobre as últimas férias dele para comentar suas descobertas com os outros colegas, mesmo que seguindo as mesmas frases utilizadas no livro didático, para prática tanto da forma (para terceira pessoa) quanto do uso do Imperfeito.

No Bem-Vindo!, a introdução do Imperfeito é feita por meio de um pequeno texto (acompanhado de fotos, ou seja, de material autêntico) que traz, além do verbo 'ser', verbos regulares e irregulares, também no Perfeito e no Presente, reproduzido a seguir:

"Nós moramos em Petrolina durante 10 anos e Josefa e eu freqüentamos a escola primária local. Mais tarde, meu pai resolveu mudar para uma cidade grande. Eu gostava do interior. Nós éramos livres lá. Me lembro que podíamos brincar na rua sem perigo e que íamos à aula a pé. Eu levava Josefa pela mão porque ela era menor. Me recordo que passava horas das minhas tardes sentada perto do riacho e que conversava com meus amigos. Nós brincávamos muito e inventávamos muitas brincadeiras.

Não assistia à televisão porque não me interessava. Aos sábados, íamos pescar com nossos pais e muitas vezes passávamos o dia inteiro fora. Minha mãe cozinhava muito bem e aos domingos após o almoço eu e Josefa ficávamos deitados na rede." (Bem-Vindo!, p. 23)

O texto é seguido pela pergunta 'E você, o que você fazia no seu país?', tentativa, a nosso ver, legítima de provocar uma situação interativa provavelmente entre professor e aluno, ou entre os próprios alunos em sala. Em seguida à pergunta, há um exercício de preenchimento de lacunas que o aluno deve preencher usando o Presente, o Perfeito ou o Imperfeito.

Para hispano-falantes, acreditamos que não haveria muitos problemas em tal exercício (e mesmo no texto introdutório), mas ficamos pensando nos falantes de outras línguas que não têm essa distinção entre Perfeito e Imperfeito em sua conjugação 
verbal - como dito anteriormente, a aquisição da forma dos verbos já é por si penosa (talvez exercícios mais estruturais pudessem ajudar aqui), imaginemos então a distinção funcional de cada tempo, especialmente dos pretéritos perfeito e imperfeito! $A$ obra deixa a cargo do professor trabalhar esses aspectos na forma de input compreensível (teoria trazida por KRASHEN, 1981, apud GERMAIN, 1996) como introdução ao capítulo que deveria fazer isso.

Por fim, ainda há um exercício de preenchimento de lacunas no qual o aluno ouve uma gravação de uma fábula (começa com 'Era uma vez...'), além de se propor que ele entreviste o colega sobre sua infância fazendo perguntas relacionadas a hobby, esporte, casa, amigos, comida, brincadeiras, para que, em seguida, faça um relato à sala.

O capítulo termina, como os anteriores, com tabelas de conjugação verbal dos verbos regulares e irregulares (pôr, ser, ter, vir) no Pretérito Imperfeito, além de outra tabela com a presente contínuo (estar + gerúndio), já que metade da unidade é dedicada a esse tempo.

Sugeriríamos o uso de material autêntico (no sentido de $\operatorname{COSTE}^{29}$, 1970, apud FRANZONI, 1992; também como sugere TOMLINSON, 2001) para a introdução do 'ser', do 'ter' e dos demais verbos no pretérito imperfeito como atividade introdutória ao capítulo do Bem-Vindo! que trata desse tempo, já que tal material, além de introduzir o imperfeito, aborda outras nuances do aluno como a cultura, a estética, etc. (como sugere SANTOS $\left.{ }^{30}, 2003\right)$.

Exemplos desse material seriam trechos de textos encontrados na mídia ou em outras fontes diversas (contos curtos, ou talvez iniciar a unidade com o próprio exercício oferecido no Bem-Vindo!, em que o aluno precisa preencher as lacunas com verbos no imperfeito dentro de um texto escrito ao modo dos contos de fadas ('Era uma vez, uma linda moça que morava num enorme castelo...' Bem-Vindo!, p. 24); uma lenda brasileira; artigos sobre os mais diversos temas como a violência na idade média comparada à dos dias de hoje; um pequeno texto de História sobre o Brasil pré-

\footnotetext{
${ }^{29}$ Material não especificamente preparado para o ensino da língua.

${ }^{30}$ Segundo essa autora, para que a construção do conhecimento seja facilitado, os diferentes aspectos humanos devem ser levados em conta: além da dimensão racional, as dimensões poética, ética, histórica, social, cultural, filosófica, subjetiva e corporal precisam ser consideradas por qualquer metodologia séria.
} 
descobrimento, aproveitando a sugestão de ALMEIDA FILHO, 2002, sobre interdisciplinaridade, etc.; ou partes de músicas como 'La Casa' de Vinícius de Moraes para os mais jovens ('era uma casa muito engraçada / não tinha teto, não tinha nada / ninguém podia entrar nela, não / porque na casa não tinha chão...) ou 'João e Maria' de Chico Buarque para os mais velhos ('agora eu era herói / e o meu cavalo só falava inglês / a noiva do caubói / era você além das outras três...).

As formas possíveis de trabalhar uma música são as mais diversas: vão desde o mero preenchimento de lacunas com os verbos ausentes ao ouvir a música, até pôr as linhas em ordem ou mesmo escrever linhas inteiras antes ou durante a audição. Tal atividade pode ser feita em duplas ou em pequenos grupos, dando oportunidade para que a interação aconteça.

Ao lado dessa atividade, poderiam ser apresentados quadros de conjugação verbal para os verbos que aparecem na música - os que lá foram conjugados, teriam de ser preenchidos pelo próprio aluno em tais quadros (esses quadros viriam ao encontro do quesito 'regras práticas', como sugere VAN PASSEL, 1983).

Depois dessa atividade introdutória em que se vê o uso do Imperfeito como descrição no passado, viriam os textos apresentados no Bem-Vindo! quando os demais verbos não vistos nas músicas poderiam ganhar seu espaço em um quadro de conjugação, além de se trabalhar também os demais usos do imperfeito.

O recurso da música é bastante utilizado no Bem-Vindo! - na introdução do Futuro do Presente, por exemplo. As músicas 'Refazenda' de Gilberto Gil ('abacateiro, acataremos teu ato / nós também somos do mato / como o pato e o leão / aguardaremos, brincaremos no regato...') e 'O Índio' de Caetano Veloso ('um índio descerá de uma estrela / colorida, brilhante / de uma estrela que virá...').

Pena, porém, que tal recurso não seja mais bem explorado, seja como atividade para treino da conjugação verbal, seja para seu uso (o Futuro do Presente é um tempo formal, utilizado geralmente na linguagem escrita).

A música de Caetano fala sobre o extermínio das nações indígenas na América do Sul, e faz uma espécie de previsão sobre um índio mitológico que descerá de uma estrela para pousar no coração deste continente. Essa idéia de mitos que falam do futuro poderia ser explorada ao se sugerir que o aluno conte histórias similares de sua cultura, ou mesmo que faça exercícios de futurologia para responder a perguntas como 
'como será o mundo do trabalho em dez anos?'; 'como será a sua vida em cinco anos?'; 'como será a internet em vinte anos?' e assim por diante.

\section{3. 'Ser' como auxiliar - a Voz Passiva}

Cunha (1983) fala sobre a voz passiva em contraste com a voz ativa, ou seja, nesta a ação é praticada pelo sujeito e naquela, o sujeito sofre a ação. Sobre a formação da voz passiva, o verbo 'ser' é usado como auxiliar, junto de um verbo principal no particípio ('ele foi chamado para o trabalho'). Além disso, Cunha fala sobre o pronome apassivador 'se' e uma terceira pessoa verbal, singular ou plural, em concordância com o sujeito: "Não se vê (=não é vista) uma rosa neste jardim. / Não se vêem (=não são vistas) rosas neste jardim". (CUNHA, 1983, p.257)

Quanto ao uso, cabe destacar que

"Na imprensa, existe certa predileção pelo uso da passiva, pois essa construção permite privilegiar a ação, não seu autor. Numa frase como: 'Foram encontrados mais dois corpos sob os escombros', pouco importa o agente da ação, ou seja, quem encontrou os corpos - é o fato em si que sobressai". (CAMARGO, 2001, s/p)

Além disso, gostaríamos de chamar a atenção para o uso de tal voz nas diversas línguas maternas dos alunos que freqüentam os cursos de português para estrangeiros. Em uma rápida análise contrastiva quanto aos usos da passiva ou por sua preferência no lugar da voz ativa em determinadas situações, não encontramos grandes diferenças entre o português e o inglês e o alemão, mas, quanto às línguas orientais, há diferenças várias em sua formação e em seu emprego, como, por exemplo, o japonês, que usa de sufixação para indicar apassivamento, além de possuir formas da passiva para indicar voz passiva prejudicial e voz passiva honorífica, idéias inexistentes na voz passiva do português (conforme SONOO, s/d, s/p).

Do nosso corpus, o Falar...Ler...Escrever... introduz a voz passiva na última unidade de sua obra por meio de uma rápida explicação sobre sua formação (verbo 'ser' mais particípio) e por um quadro com frases na voz ativa em todos os tempos 
verbais vistos até então, transformadas para a passiva na página 257 , quadro esse reproduzido a seguir:

\begin{tabular}{|l|l|}
\hline Quadro 5 & A voz passiva no Falar...Ler...Escrever... \\
\hline \multicolumn{1}{|c|}{ Voz ativa } & \multicolumn{1}{c|}{ Voz passiva } \\
\hline Todo mundo lê este jornal. & Este jornal é lido por todo mundo. \\
Todo mundo lia este jornal. & Este jornal era lido por todo mundo. \\
Todo mundo leu esta notícia. & Esta notícia foi lida por todo mundo. \\
Todo mundo lerá esta notícia. & Esta notícia será lida por todo mundo. \\
Todo mundo leria esta notícia. & Esta notícia seria lida por todo mundo. \\
Todo mundo está lendo estes artigos. & Estes artigos estão sendo lidos por todo mundo. \\
Todo mundo estava lendo estes artigos. & Estes artigos estavam sendo lidos por todo mundo. \\
Todo mundo tem lido estes artigos. & Estes artigos têm sido lidos por todo mundo. \\
Todo mundo tinha lido estas cartas. & Estas cartas tinham sido lidas por todo mundo. \\
Quero que os alunos leiam este livro. & Quero que este livro seja lido pelos alunos. \\
Eu quis que meus amigos lessem este livro. & Eu quis que este livro fosse lido pelos meus amigos. \\
Vocês entenderão tudo quando lerem estas & Vocês entenderão tudo quando estas cartas forem \\
cartas. & lidas. \\
\hline
\end{tabular}

Tal quadro é seguido por um exercício de transformação da voz ativa para a voz passiva de diversas frases soltas, além de uma pequena tabela com alguns verbos abundantes, ou seja, que têm duas formas no particípio, seguida de uma rápida explicação sobre o uso do particípio regular na voz ativa (com os verbos auxiliares 'ter' e 'haver') e o irregular na voz passiva (com o auxiliar 'ser'), além de exemplos na passiva com os verbos auxiliares 'poder', 'precisar', 'dever', 'ter que' e 'ter de', seguidos por atividades de preenchimento de lacunas com frases soltas.

Por fim, uma rápida explicação é dada sobre a formação da voz passiva com o pronome apassivador 'se' (vende-se um apartamento = um apartamento é vendido / vendem-se casas = casas são vendidas), seguida por um exercício de transformação de frases soltas na passiva analítica para a passiva com pronome apassivador, além de outro exercício para que o aluno indique o tempo da conjugação verbal de diversas frases soltas na voz passiva, e de outro ainda para que o aluno faça frases na voz ativa e depois na passiva utilizando os verbos dentro de temas como 'televisão (comprar, vender, ver, ligar, desligar, etc.), livro (ler, escrever, comprar, etc.) e 'casa' (comprar, alugar, vender, pintar, etc.) sugeridos no próprio LD.

Há ainda uma atividade de transformação de frases da voz passiva para a voz ativa e um texto autêntico de Luiz Fernando Veríssimo, no qual o autor fala de segurança em um condomínio utilizando verbos na voz passiva por diversas vezes ('toda área era cercada por um alto muro'; 'agora não só os visitantes eram obrigados a 


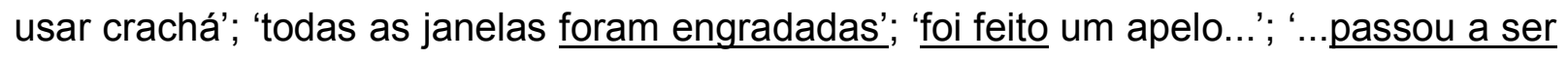
feito um rigoroso controle das saídas'; 'foi reforçada a guarda'; 'foi tomada uma medida extrema'; ' a guarda tem sido obrigada a agir com energia').

Destacamos essa última atividade, a de leitura de texto seguida de interpretação, especialmente por causa de sua autenticidade e pela tentativa legítima das autoras de contextualizar o uso da voz passiva em um texto que pode ser encontrado no dia-a-dia, seja em jornais ou revistas, demonstrando os usos de tal voz para determinadas situações.

Sentimos, contudo, a falta de outra atividade um pouco mais intensiva sobre esse texto, como, por exemplo, simplesmente sublinhar os verbos utilizados na passiva tentando, ao mesmo tempo, explicar o porquê daquela escolha em alguns dos casos, ou simplesmente uma atividade de transformação desses verbos para a voz ativa, seja em duplas, seja em pequenos grupos.

Uma ou duas perguntas-objetivo poderiam ser introduzidas no início do texto, como nos sugere Kleinman (2002), para que a inferência de sentidos seja facilitada, além de exercícios de compreensão e, é claro, perguntas sobre a opinião do aluno a respeito e se em seu país há a necessidade de tantas medidas de segurança e por quê. Tais perguntas trariam a possibilidade de participação ativa do aluno em seu aprendizado, já que ele traz elementos de sua própria cultura para a sala de aula, elementos esses que precisam ser expressos em português: a troca de papéis entre professor e aluno, aquele já não sendo o detentor da informação a ser trabalhada em sala, faz da relação professor - aluno muito mais simétrica ${ }^{31}$.

Outra atividade interessante por enfocar leitura e escrita, seria sugerir aos alunos que tentassem reescrever ou recontar a história de Veríssimo utilizando a passiva sempre que possível, ou ainda pedir aos alunos que escrevam pequenas histórias a partir dos verbos sublinhados na atividade de identificação proposta mais acima - em 'foi tomada uma medida extrema', por exemplo, pequenas narrações poderiam surgir sobre cenários políticos ou empresariais, história do país do aluno ou sua própria história, casos de furtos em uma empresa, entre inúmeros outros. A questão poderia

\footnotetext{
${ }^{31}$ A importância de um relacionamento mais simétrico entre professor e aluno para que este possa (re)construir seu conhecimento de maneira mais efetiva nos é apontada por Demo (2002) e Almeida Filho (2002).
} 
ser aberta (as possibilidades de narrativas diferentes seriam inúmeras) ou mais dirigida, conforme o objetivo do autor do livro didático.

Essas histórias poderiam ser lidas em grupo ou para a sala toda e discutidas ou comentadas, poderiam ser 'julgadas' por um júri composto pelos próprios alunos que deveriam sugerir melhoras aqui e ali e premiar as melhores - dessa forma, abrir-se-ia um espaço para a discussão em sala e para que diversos aspectos outros da língua fossem explorados já que, segundo Germain (1996), um debate nesse nível em que os alunos se encontram (já não se trata de iniciantes) traria grandes benefícios a todos os participantes.

O Avenida Brasil 2 introduz a voz passiva em sua primeira unidade por meio de um pequeno texto que fala sobre a língua portuguesa no mundo. Tal texto é seguido por uma entrevista em cassete com o autor português, José Saramago, na qual fala-se sobre sua obra $A$ jangada de pedra e as diferenças entre o português falado em Portugal e no Brasil. Atividades de entendimento de texto com respostas em forma de múltipla escolha são propostas ao aluno, seguidas por uma proposta de debate sobre o português falado em Portugal (se é rápido demais, se é difícil de entender, se há palavras diferentes, etc.).

Em seguida, vêm destacadas em um quadro as diversas ocorrências no texto e na entrevista da voz passiva com o verbo 'ser', uma atividade para ordenar frases e outra na qual o aluno deve falar com o colega para responder a perguntas na voz ativa usando a voz passiva ('quem inventou o avião? / o avião foi inventado por Santos Dumont', etc.). As perguntas vêm com o verbo principal no infinitivo, ao lado de um quadro com nomes a serem usados nas respostas ('quem... escrever $A$ Jangada de Pedra? - Tom Jobim / José Saramago / Thomas Edison', etc.).

Outro quadro é apresentado com frases na voz ativa e na passiva que demonstram o uso de alguns dos verbos abundantes (com dois particípios), além de uma atividade de preenchimento de lacunas, na qual o aluno precisa escrever a forma do particípio regular para os verbos sugeridos e encontrar em uma tabela as formas irregulares desses mesmos verbos.

Por fim, um último quadro traz exemplos de frases com verbos na passiva pronominal e na analítica, quadro esse seguido de uma atividade em que alguns verbos 
são sugeridos para se completarem pequenos anúncios de aluguel ou venda de propriedades, contratação de profissionais, etc.

Sentimos nessas duas últimas partes, sobre a voz passiva pronominal e a com verbos abundantes, a falta de atividades mais interativas - a própria resolução dos exercícios poderia ter sido buscada em duplas ou em grupos, além de atividades paralelas como a formação de frases utilizando os verbos com dois particípios e, a partir de algumas dessas frases, um texto ou um debate em grupo, dependendo sempre do conteúdo sugerido pelos alunos nessas frases ${ }^{32}$.

Atividades pré-comunicativas também poderiam ser utilizadas aqui, como, por exemplo, a busca de anúncios na internet ou em jornais, que geralmente utilizam a voz passiva pronominal (procura-se gerente; procuram-se secretárias) com a desculpa de se pesquisar o mercado de trabalho para gerentes ou engenheiros ou professores universitários, etc. - os anúncios seriam trazidos para a sala de aula e utilizados para a elaboração de uma carta-resposta ou de um currículo.

Outra sugestão é os alunos imaginarem uma empresa e anunciarem vagas para empregos nela em um jornal - assim a redação desse tipo de linguagem poderia ser trabalhada. Os anúncios circulariam pela sala e outros grupos poderiam respondê-los ou ainda refazê-los, quando necessário.

Como Camargo (2001) chama a atenção para a preferência do uso dessa voz pela imprensa, textos dessa modalidade poderiam ser lidos em sala ou mesmo em casa na busca de ocorrências da voz passiva e de uma possível explicação para tal preferência naquele contexto.

O Fala Brasil introduz a voz passiva por meio de uma atividade de sistematização na qual explica a formação de tal voz: "Verbo SER no mesmo tempo do verbo principal + PARTICÍPIO - O cachorro mordeu o menino / o menino foi mordido pelo cachorro" (Fala Brasil, p. 170), além de descrever as etapas para a transformação da voz ativa para a passiva identificando antes o tempo do verbo principal, depois conjugando o verbo 'ser' nesse mesmo tempo e colocando o principal no particípio,

\footnotetext{
${ }^{32}$ Como nos lembra Tomlinson (2001), o autor do LD não pode confiar demais em atividades controladas, já que essas não garantem a acuidade e a fluência a longo prazo. Aceitar sugestões dos próprios alunos traria então um pouco do 'caos' aparente da língua, o que estaria fora de controle, promovendo a fluência.
} 
seguida da descrição da ordem dos fatores na frase ('mudar $a . . . b$ para $b \ldots$ por+a') e fazer a concordância.

Uma atividade de preenchimento de lacunas é proposta a fim de treinar as etapas de transformação de uma voz para a outra, e outra atividade para concordância (fechar a porta - porta fechada, etc.). Outros exercícios de transformação são propostos, além de um quadro com os principais verbos abundantes, seguido por dois exercícios de transformação de uma voz para a outra.

Atividades interativas não são encontradas na abordagem do assunto pelos autores, além de ter sido ignorada a voz passiva pronominal. Há excesso de explicações quanto à forma e faltam esclarecimentos quanto ao uso da voz passiva não que tudo deva ser explicado, mas sim utilizado em atividades, sejam estruturalistas ou mais comunicativas, para que o próprio aluno acabe chegando às conclusões de como utilizar tal voz. O quadro de verbos abundantes parece bem completo, porém muito mal utilizado, já que as atividades que o seguem são muito curtas para uma abordagem mais abrangente.

O Bem-Vindo! introduz a voz passiva por meio de textos escritos e orais na unidade 8, unidade esta regida pelo tema 'português no mundo'. A voz passiva vem introduzida por um texto que descreve o Brasil, fala de suas fronteiras ('esta imensidão cercada pelo Oceano Atlântico, pelas Guianas, pelo Suriname...' (Bem-Vindo!, p. 73)), de suas lendas, de seus atrativos para os estrangeiros, etc.

Tal texto é bem escrito e poderia ser mais bem utilizado se houvesse perguntas de entendimento de texto para dar um objetivo à leitura (conforme nos aponta KLEIMAN, 2002), e se as atividades posteriores partissem de seu conteúdo.

Logo depois vem um exercício de escuta em que o aluno deve ouvir um diálogo e preencher os espaços em branco no diálogo impresso no livro. São diversos os assuntos abordados nessa atividade, que vêm em forma de perguntas e respostas sobre diversos fatos históricos do Brasil e do mundo ('qual o único presidente do Brasil deposto pelo processo de 'impeachment'? / 'Quando o muro de Berlim, na Alemanha, foi derrubado?').

Em seguida, vem uma atividade bastante interativa a ser feita em duplas, na qual sugerem-se alguns itens necessários a uma festa, uma viagem ao exterior e uma 
mudança. Cada componente da dupla deve perguntar ao outro se tal e tal item já foi providenciado, se a passagem já foi comprada, se a transportadora já foi contactada, etc.

Essa atividade é seguida por outra de transformação das frases na voz ativa para a voz passiva, escritas pelo próprio aluno a partir de desenhos disponíveis no livro, seguindo um exemplo no início da atividade. Há ainda um exercício de escuta em que o aluno precisa marcar, em frases na passiva, as palavras que não correspondem ao que ele ouviu na gravação.

A última atividade que treina o uso da voz passiva encontra-se em um texto sobre a comunidade dos países de língua portuguesa (CPLP), quando foi criada, do que trata, o papel dado à língua portuguesa no mundo, etc. Tal texto vem seguido de perguntas de compreensão e uma última pergunta pedindo a opinião do aluno sobre se deveria ou não existir a CPLP e por quê.

A abordagem da voz passiva no Bem-Vindo! está, em nosso ponto de vista, bastante completa e de acordo com o paradigma complexo e teorias afins. O pano de fundo utilizado para treinar tal voz, a língua portuguesa no mundo, foi uma escolha bastante feliz porque traz ao aluno a oportunidade de conhecer um pouco mais das diferenças de vocabulário e um pouco da cultura de países falantes do português. Além disso, estão disponíveis no cd que acompanha o livro diversas músicas nessa língua de diferentes cantos do mundo.

As atividades, em geral, trazem a oportunidade de interação (intensa negociação de sentidos, de acordo com GERMAIN, 1996), de enfoque no oral sem esquecer a escrita, além de contextualização intensa, seja por meio de textos escritos, seja por meio de músicas e diálogos gravados.

Os três livros de exercícios trazem ainda a oportunidade de sistematização do uso da voz passiva por meio de exercícios de transformação (voz ativa para a passiva) e de expansão vocabular por meio de atividades para criar textos, apesar de o livro voltado a falantes de línguas asiáticas não mencionar a inexistência de formas específicas da voz passiva prejudicial e honorífica em português, como nos apontou Sonoo (s/d). 


\section{Análise do Corpus - O verbo 'ter'}

\subsection{Introdução do verbo 'ter' nas obras analisadas}

Gomes (s/d), classifica o verbo 'ter' como um verbo leve, ou seja, semanticamente vazio que se associa a outros elementos para ganhar um novo significado de acordo com o elemento a que ele se liga. Ainda segundo Gomes, são vários os usos do verbo 'ter' no Português do Brasil, dos quais ele destaca o existencial ('tem muita gente nesta sala'), o auxiliar ('ela tem participado de muitas bancas de mestrado'), de manter ('Sérgio tem muita gente em suas mãos') e de sentir ('Paulo tem dores terríveis').

Exceto o uso existencial, ainda considerado informal pelas gramáticas normativas, e o auxiliar por tratarmos dele em capítulo à parte, vejamos como as obras de nosso corpus abordam a introdução da forma e do uso do verbo 'ter' no sentido de 'manter' e de 'sentir' apontados por Gomes (s/d).

Na unidade 2 de Falar...Ler...Escrever... esse verbo é introduzido no Presente do Indicativo no diálogo inicial e em um quadro de conjugação para eu / você/ele/ela / nós / vocês/eles/elas, seguido de exercícios de preenchimento de lacunas, de outro para responder a perguntas usando o advérbio de negação 'não', e outro ainda para ligar imagens a frases com o verbo 'ter' (eu tenho azar; ele tem muita sorte; nós temos muitos filhos; ela tem 15 anos, este último exemplo como boa oportunidade de contrastar o português com o inglês e o alemão que usam o verbo 'ser' para expressar idade: I'm 15 years old; ich bin 15 Jahre alt, respectivamente).

Exercícios similares são usados para sedimentar a conjugação de 'ter no Pretérito Perfeito na unidade 5 da obra (ao lado de 'estar', 'ser' e 'ir', conforme já descrito no item 6.2), e no Pretérito Imperfeito na unidade 8, ao lado de outros irregulares nesse tempo verbal como 'ser' e 'pôr'.

$\mathrm{Na}$ unidade 9, há uma atividade de perguntas e respostas em que o aluno precisa responder utilizando os sinônimos 'precisar(de)', 'ter de' ou 'ter que', no sentido de necessidade ou de obrigação, além de outro para completar inícios de frases que 
utilizam esses verbos, tudo logo após uma tabela que indica a correspondência entre as três formas.

No Avenida Brasil 1, o verbo 'ter' é introduzido em uma tabela de conjugação na lição 1, ao lado de outro verbo irregular, o 'poder', com 'ter' seguido de alguns complementos (não ter tempo, ter muito trabalho, não ter carro, não ter dinheiro, ter programa), mas sem nenhuma atividade que sedimente o uso desse verbo.

O Pretérito Perfeito de 'ter' é introduzido na lição 6, ao lado dos verbos 'estar' (com conjugação semelhante à de 'ter' neste tempo, dessa vez com palavras entre barras para formar frases (eu/aula de judô/reunião no escritório - Não estive na aula de judô. Tive reunião no escritório)), além de outra atividade que mistura diversos verbos irregulares para que o aluno preencha as lacunas de acordo com o sentido das frases. Por fazer parte dos 4 únicos verbos irregulares no pretérito imperfeito, 'ter' é apresentado ao lado do verbo 'ser' na lição 8, o que, como já mencionado, responde bem ao quesito 'necessidade de regras práticas' apontada por van Passel (1983).

No Fala Brasil, 'ter' é apresentado na unidade 5 como parte de uma tabela de expansão de verbos irregulares no presente (dar, trazer, pôr, vir, ter, fazer), seguida de pequenas perguntas e respostas usando o próprio verbo, como forma de ilustração (você tem? - tenho / ele dá? - dá, etc.).

Destaca-se uma explicação oferecida mais à frente, sobre a semelhança semântica entre 'ter' e 'estar com', em que o primeiro traz a idéia de algo permanente, habitual, contínuo, característico; o segundo traz a idéia de transitoriedade, mutabilidade, algo provisório (ter/estar com frio; ter/estar com medo; ter/estar com raiva, etc.), logo depois de duas colunas com frases que ilustram tal diferença (vou viajar amanhã - estou com medo de tomar o avião / você tem medo de viajar de avião?).

A correspondência entre 'ter de', 'ter que' e 'precisar' também é destacada na unidade 8 da obra, porém somente em forma de nota, sem nenhuma atividade destinada a treinar o uso de tais verbos.

Uma sugestão para a introdução e uso do verbo 'ter' de forma mais interativa e que envolva outras nuances do aluno, como a noção estética, por exemplo, seria apresentar no livro didático algumas fotos de figuras humanas das quais os alunos, em 
duplas, precisariam enumerar o maior número possível de características como: ele tem cabelos castanhos, tem olhos verdes, provavelmente tem $1 \mathrm{~m} 80$ de altura, tem aproximadamente 20 anos, etc.

A diferença entre 'ter' e 'estar com' pode ser explorada em figuras de rostos que demonstrem certas emoções ou estados de ânimo, também para descrição em duplas: ela está com dor de dente (para uma figura de alguém com o rosto inchado); ele tem problemas (para a figura de alguém que demonstre aflição). O vocabulário poderia ser oferecido por meio de alternativas para cada rosto a fim de facilitar sua expansão e uso: a) ele está com febre; b) ele tem problemas; c) ele está com dor de barriga.

Outra sugestão para uso do 'ter' no passado (e do 'estar', já que suas formas nesse tempo são semelhantes) seria fazer uma pesquisa com os colegas a partir de um quadro com diversas possibilidades como: descubra quem... já teve sarampo; já esteve em um hospital; esteve em um CTI; etc., tudo contextualizado no tema da unidade em que tais verbos são introduzidos. A expansão vocabular de que nos fala Tan (2004), com certeza teria vez em qualquer uma dessas duas últimas sugestões.

A partir dessas atividades, outra que explora o uso informal de 'ter' no sentido de 'existir' (substituindo 'haver') poderia ser utilizada, também sob a forma de questões com múltipla escolha: 'nesta página há/tem algumas figuras humanas - um homem a) branco; b) moreno; c) oriental'. A partir do vocabulário apresentado nessa atividade, o aluno poderia ser convidado a descrever seus colegas, seu escritório, sua casa, entre inúmeras outras possibilidades.

Tal atividade, posterior às demais que introduzem e sedimentam 'ter' em funções aceitáveis pela norma padrão, ofereceria ao aluno a oportunidade de um contato com a linguagem informal na ordem defendida por Kunzendorff (1997), já que essa autora defende a idéia de que passar da linguagem formal para a informal é muito mais fácil do que o contrário. 


\subsection{O 'ter' como auxiliar}

\subsubsection{Os tempos compostos do Indicativo}

Segundo Cunha (1983), temos no modo indicativo do Português, o Pretérito Perfeito Composto (tenho estudado), o Pretérito Mais-que-Perfeito Composto (tinha estudado), o Futuro do Presente Composto (terei estudado) e o Futuro do Pretérito Composto (teria estudado). No modo subjuntivo, temos o Perfeito Composto (que eu tenha morado), o Mais-que-Perfeito Composto (se eu tivesse morado) e o Futuro Composto (quando eu tiver morado), todos formados pelo verbo 'ter' conjugado mais o verbo principal no particípio. Esse mesmo autor não explica os diversos usos de cada tempo, provavelmente por sua obra ser dirigida ao público de falantes nativos do português, caso diferente dos livros didáticos aqui analisados.

Como são vários os tempos compostos, tomamos o cuidado de escrever seus nomes em negrito para uma melhor localização visual.

\subsubsection{O Pretérito Perfeito Composto do Indicativo}

Comecemos, então, pelo Pretérito Perfeito Composto do Indicativo (tenho estudado) e sua introdução nos LDs analisados pelo presente trabalho. Segundo Costa (2002), esse tempo verbal "é o único tempo composto do português que pode, em certas circunstâncias, portar traço de imperfectividade (tem vivido), enquanto um tempo simples, como o Pretérito Imperfeito, também pode portar esse traço de marca aspectual" (COSTA, 2002, p. 45).

Essa mesma autora descreve o Pretérito Perfeito Composto, citando Illari, como um tempo que exprime reiteração (nesse caso, não exprime imperfectividade, como em 'muitos estrangeiros têm vindo para o Brasil'); que assume eventualmente um valor de continuidade ('você tem levado o seu filho ao parque?'); tempo cuja repetição ou continuidade a que se refere diz respeito a um período que, começando no passado, alcança o momento da fala e eventualmente o ultrapassa.

Ilari (2001) afirma que "o fato descrito por uma sentença com o auxiliar 'ter' num tempo verbal qualquer aparece como passado em relação ao tempo em que se localizaria, se aquele morfema de tempo fosse aplicado à base verbal” (ILARI, 2001, p. 
29), já que 'ter' como auxiliar comuta com formas simples ('fizera' por 'tinha feito'), não tem o mesmo sentido de quando é o verbo principal, e sua combinação com outros verbos principais no particípio indica uma única ação atribuída a um único sujeito ('tenho invejado muitos vizinhos' comparado a 'tenho muitos vizinhos invejados').

No Falar...Ler...Escrever... explica-se que o Pretérito Perfeito Composto "expressa uma ação que se iniciou no passado e continua no presente" (Falar...Ler...Escrever..., p. 232). Esse tempo é introduzido na unidade 17 juntamente aos demais tempos compostos do Indicativo, com exceção do Pretérito Mais-quePerfeito Composto do Indicativo, por meio de um diálogo e de uma tabela de conjugação.

No diálogo, reproduzido a seguir, introduzem-se inclusive o Perfeito e o Maisque-Perfeito Composto do Subjuntivo:

\section{'Desastre!}

Meu Deus! O que foi que aconteceu?

Um desastre! Bati o carro.

Mas como?

$\mathrm{Na}$ hora $\mathrm{H}$, o freio falhou.

Alguém se machucou?

Não, ninguém. Foi só um susto. Mas meu carro acabou.

Ninguém? Ainda bem! Então não se aborreça. A gente, que anda o dia inteiro de carro, para cima e para baixo, está sujeito a essas coisas. A batida parece que foi feia, mas talvez você tenha tido sorte. Poderia ter sido pior. E o seu seguro, naturalmente, vai pagar o prejuízo...

É aí que está o problema. Sempre tive seguro. Mas ultimamente tenho tido problemas no escritório. Poucos clientes, pouco dinheiro, você sabe como é. Por isso deixei de pagar o seguro. Anos e anos pagando e nenhum acidente. Agora...

Que situação! Garanto que se você tivesse pago o seguro direitinho, você não teria batido. É sempre assim.

É, eu sei. Azar meu!' (Falar...Ler...Escrever..., p. 231)

Observamos o uso de diversos tempos verbais no diálogo, o que, a essa altura do método (unidade 17) mostra-se bastante positivo, pois retoma os tempos já aprendidos em outras unidades em novos contextos, o que respeita a característica de circularidade da construção do conhecimento pregada pelo paradigma composto.

Vemos o presente do indicativo com a noção de habitualidade, o pretérito perfeito do indicativo com a noção pontual de ação acabada, além de expressões com 
o verbo ser ('o que foi que...' e 'é aí que') e do condicional que indica probabilidade quase nula ('se você tivesse pago o seguro direitinho, você não teria batido').

Nos exercícios, a autora tenta associar a noção de uso do Pretérito Perfeito Composto a expressões de tempo como 'ultimamente' e 'desde que' (ultimamente tenho trabalhado muito / tenho estado doente desde que cheguei ao Brasil) em frases soltas.

Há também um exercício mais contrastivo, que pede ao aluno para optar entre esse tempo verbal e o perfeito simples (tenho falado - falei) ao preencher as lacunas de frases soltas que carregam marcadores de tempo como 'ontem', além do 'ultimamente' e do 'desde que' indicados acima. O último exercício sobre o tema pede ao aluno que escreva o que ele tem feito nos últimos meses/ultimamente, bastante positivo, a nosso ver, já que força o aluno a falar de seu cotidiano na língua-alvo ou em sua interlíngua ${ }^{33}$.

De certa forma, a contextualização desse tempo verbal ocorre satisfatoriamente no Falar...Ler...Escrever... além de deixar claro que o pretérito perfeito composto geralmente traz a noção de eventos reiterativos ou que iniciaram no passado e, de alguma forma, continuam no presente (tenho ido muito aos museus, tenho estudado português, etc.).

Por outro lado, o método não oferece aqui atividades mais interativas, seja com os colegas, seja com o professor. Poder-se-ia utilizar uma tabela de perguntas sobre coisas que os colegas têm ou não têm feito durante a semana, durante o mês, durante o curso, durante a sua estada no Brasil, durante o seu lazer, enfim, uma série de situações ligadas ao dia-a-dia (portanto relevantes) às quais o aluno deveria responder sobre os colegas via entrevista ou até sobre si mesmo.

Essa atividade interativa seria possibilitada por meio de um questionário ao qual o aluno responderia a partir das respostas que obtivesse de seus colegas, como: 'descubra quem... tem assistido a novelas ultimamente; tem ido ao teatro; tem trabalhado muito; tem feito compras na feira; tem comido muita pizza' e diversas situações do cotidiano para que o aluno pudesse circular pela sala e descobrir um pouco sobre seus colegas ou professor.

\footnotetext{
33 “(...)língua de transição entre a língua nativa e a língua-alvo em certa altura do processo de
} aprendizagem" (MOITA LOPES, 1996, p.114) 
No Avenida Brasil 2, o Pretérito Perfeito Composto do Indicativo (tenho feito) é introduzido na primeira unidade em forma de uma tabela de conjugação a ser preenchida pelo aluno, ao lado de uma rápida explicação sobre a composição de tal tempo e seu uso: "O pretérito perfeito composto do indicativo indica ação não terminada. A ação iniciou-se no passado e continua no presente" (Avenida Brasil, p.12).

Tal explicação é seguida por três frases-exemplo que associam o perfeito composto ao uso do advérbio de freqüência 'ultimamente' ('Ultimamente tem aumentado a preocupação...'; 'ele falou português na terça, na quinta, na sexta e ontem: ele tem falado muito português ultimamente'; 'li um livro por semana no mês passado e continuo lendo bastante: tenho lido muito ultimamente').

Esse quadro explicativo é seguido por um exercício de conjugação no qual o aluno precisa ligar colunas para formar frases ao mesmo tempo em que conjuga o verbo principal no perfeito composto e é convidado a completar cada frase com informação própria.

Já que as noções de iteração e de continuidade apontadas por Costa (2002), estão presentes nessa curta introdução do perfeito composto, fiquemos com nossas sugestões para uma sedimentação mais completa de tal tempo.

A falta de contextualização nos exemplos usados pelos autores no Avenida Brasil 2 poderia ser compensada por meio de diálogos ou de um texto que falasse sobre como tem sido a vida de um determinado estrangeiro em São Paulo, por exemplo.

A partir desse texto, exercícios interativos poderiam ser propostos, como entrevistas, atividades em duplas ou em grupos, cujos temas possíveis de exploração poderiam ser o cotidiano do aluno em comparação ao cotidiano do estrangeiro retratado no texto da atividade, ou mesmo sobre o tempo nas últimas semanas, o quadro político do País ou do mundo, alimentos transgênicos (tema tão controverso para americanos, por exemplo) - o que o aluno tem visto nos meios de comunicação para uma maior conscientização dos consumidores, ou mesmo temas mais 'leves', voltados aos mais jovens, como tendências da moda, dos esportes, da música popular, ou mesmo aonde têm ido ultimamente, a barzinhos, danceterias, relacionados sempre ao dia-a-dia do aluno (aqui se responderiam aos quesitos relevância, contextualização, consideração dos conhecimentos prévios do aluno, entre outros). 
No Fala Brasil, o Pretérito Perfeito Composto do Indicativo é introduzido praticamente no final da obra por meio de um diálogo ao lado de uma tabela de conjugação com verbos principais em -ar, -er e -ir (tenho jogado, tenho bebido, tenho dormido), seguida de uma nota sobre a equivalência entre esse tempo e a perífrase 'andar + gerúndio' (tenho trabalhado muito = ando trabalhando muito).

Um exercício de completar lacunas conjugando o perfeito composto vem em seguida, de forma bastante contextualizada, já que se trata de pequenos diálogos ('E o Flavinho, você tem visto? / Ele andava meio sumido, mas depois que a minha sobrinha mudou pra cá, ele tem vindo sempre aqui').

A introdução do perfeito composto no Fala Brasil termina com um quadro contrastivo entre esse tempo e o present perfect continuous do inglês ('eu tenho trabalhado muito $=$ I have been working too much), a nosso ver, bastante esclarecedor para anglo-falantes quanto à noção de ação que se iniciou no passado e continua no presente.

Apesar de responder aos quesitos 'contextualização' e 'consideração da língua materna do aluno', faltam ao Fala Brasil atividades interativas mais ligadas ao cotidiano desse aluno ou mesmo a temas mais 'universais' como economia, saúde, nutrição, entre outros, que poderiam ser usados como forma de provocar debates entre alunos das mais diversas faixas etárias e com os mais diversos interesses, já que tais temas muitas vezes trazem em si a controvérsia. Além disso, esses temas poderiam aproveitar tanto o conhecimento prévio do aluno da língua-alvo quanto a sua base cultural, além de trazer oportunidades de ampliação vocabular, privilegiando sempre a interação e o oral.

No Bem-Vindo!, o Pretérito Perfeito Composto do Indicativo (tenho feito) é introduzido em um quadro explicativo na página 102 com todos os tempos compostos do português. Reproduzimos o quadro a seguir: 


\begin{tabular}{|c|c|c|}
\hline Quadro 6 & Os tempos compostos no Bem-Vindo! & \\
\hline & Indica & Exemplo \\
\hline Tenho estudado & $\begin{array}{l}\text { Repetição ou prolongação de um fato } \\
\text { até o momento em que se fala. Fato } \\
\text { habitual. }\end{array}$ & $\frac{\text { Tenho trabalhado muito }}{\text { ultimamente. }}$ \\
\hline Tinha estudado & Ação anterior a outra já passada. & $\begin{array}{l}\text { Quando cheguei, ele já tinha ido } \\
\text { embora. }\end{array}$ \\
\hline Terei estudado & $\begin{array}{l}\text { Ação completada em um determinado } \\
\text { tempo futuro. }\end{array}$ & $\begin{array}{l}\text { Até as } 4 \text { horas terei terminado de } \\
\text { digitar esse relatório. }\end{array}$ \\
\hline Teria estudado & \begin{tabular}{|l|} 
Afirmação em relação ao passado \\
(geralmente depende de uma condição).
\end{tabular} & $\begin{array}{l}\text { Se tivesse dinheiro, teria comprado } \\
\text { aquele carro. }\end{array}$ \\
\hline Tenha estudado & $\begin{array}{l}\text { Usada nas mesmas circunstâncias do } \\
\text { Presente do Subjuntivo, porém para } \\
\text { expressar uma ação no passado. }\end{array}$ & $\begin{array}{l}\text { Eu duvido que ele tenha feito a } \\
\text { tarefa. }\end{array}$ \\
\hline Tivesse estudado & $\begin{array}{l}\text { Usada nas mesmas circunstâncias do } \\
\text { Imperfeito do Subjuntivo, porém para } \\
\text { expressar uma ação no passado. }\end{array}$ & $\begin{array}{l}\text { Eu teria ido à festa se tivesse sido } \\
\text { convidado. }\end{array}$ \\
\hline Tiver estudado & $\begin{array}{l}\text { Uma ação terminada no passado ou que } \\
\text { terminará num determinado tempo no } \\
\text { futuro. Usada nas mesmas } \\
\text { circunstâncias do Futuro do Subjuntivo. }\end{array}$ & $\begin{array}{l}\text { Se nesse dia eu não tiver viajado, } \\
\text { irei ao seu aniversário. }\end{array}$ \\
\hline
\end{tabular}

Acreditamos ser bastante esclarecedor tal quadro, especialmente porque é introduzido a uma altura em que o aluno, teoricamente, domina os tempos simples tanto do indicativo quanto do subjuntivo.

Detectamos, contudo, uma grande falha no método porque os tempos compostos são pouco ou nada sedimentados nas atividades que seguem, apesar de essas atividades serem bastante interativas, contextualizadas (há inúmeros textos) e voltadas também à escuta, porém de outros aspectos lingüísticos e não dos tempos compostos. Somente uma dessas atividades está mais voltada à conjugação e ao uso do perfeito composto, e se trata de um exercício de perguntas e respostas no qual somente duas das perguntas utilizam tal tempo.

O Imperfeito Composto do Subjuntivo (tivesse feito) é mais utilizado em uma atividade que propõe ao aluno repassar a sua vida com frases condicionais como 'se as coisas tivessem sido diferentes' ou 'se você tivesse feito coisas diferentes', e pede ao aluno que escreva 5 situações seguindo o exemplo: 'Se eu não tivesse ganho a bolsa de estudos para ir estudar no exterior, nunca teria saído do Brasil' (Bem-Vindo!, p. 105). Mesmo os livros de exercícios que acompanham a obra têm somente um exercício cada para todos os tempos compostos, ora de preenchimento de lacuna, ora de perguntas e respostas. 
O método deixa mais uma vez a cargo do professor adaptar as atividades propostas para que o aluno compreenda o uso dos tempos compostos na forma de input compreensível, já que, segundo o paradigma complexo e teorias afins, a aquisição dos aspectos lingüísticos geralmente acontece por meio da interação social e de atividades relevantes, não somente por um quadro explicativo.

\subsubsection{O Pretérito-mais-que-perfeito Composto do Indicativo}

O Pretérito-mais-que-perfeito Composto do Indicativo (tinha feito) é introduzido no Falar...Ler...Escrever... uma unidade antes da que introduz a forma simples desse tempo (fizera). Não há explicações quanto ao seu uso, somente uma tabela de conjugação, alguns exemplos com os verbos das diferentes conjugações verbais (comprar/vender/partir), uma tabela com os principais particípios irregulares e alguns exemplos dos regulares, tudo seguido por dois exercícios de preenchimento de lacunas nos quais o aluno treina a conjugação nesse tempo, em frases combinadas tanto com o pretérito perfeito quanto com o imperfeito o que, a nosso ver, evidencia o uso do mais-que-perfeito composto como uma forma de retratar uma ação no passado (momento do evento) anterior a outra (momento de referência, no pretérito perfeito ou imperfeito do indicativo). Há ainda um terceiro exercício que pede ao aluno para completar a resposta a uma pergunta, seguindo sempre uma frase-modelo.

$\mathrm{Na}$ unidade 12 da obra, logo depois de ser introduzido o presente do subjuntivo, a forma simples do mais-que-perfeito aparece em tabelas de conjugação ao lado de um exemplo: 'O carro não estava onde ele tinha deixado. $O$ carro não estava onde ele deixara'.

As autoras do Falar...Ler...Escrever... não explicam a diferença de uso entre o composto e o simples, o que dá a entender que o professor precisa fazer isso. A obra só traz explicações sobre a formação do mais-que-perfeito simples (a partir da $3^{a}$. pessoa do plural do pretérito perfeito do indicativo), seguidas de um exercício de conjugação e outro para o aluno passar as frases da forma composta para a simples. Depois, nada mais é proposto ao aluno para que utilize as estruturas introduzidas nas mais diversas situações em que poderiam ser usadas. 
Poderíamos sugerir, então, pequenas tiras de histórias em quadrinhos com situações diversas, cujos balões precisariam ser preenchidos individualmente pelo aluno ou em duplas, para que o mais-que-perfeito fosse utilizado.

Além disso, ainda vale a técnica da entrevista sugerida por Galloway (1993), com perguntas como: 'quando você chegou à sala hoje, a aula já tinha começado?'; 'quando você acordou hoje, o despertador já tinha tocado?'; 'quando você tomou café da manhã, você já tinha ligado a televisão?'; ou ainda, perguntas 'em corrente' como: 'quando você chegou à sala hoje, você já tinha feito a tarefa?'; 'quando você fez a tarefa, já tinha entendido as estruturas estudadas em sala?'; 'quando você estudou as novas estruturas, você já tinha feito a tarefa da aula anterior?', entre inúmeras outras possibilidades, seja sobre o ambiente de trabalho, seja sobre o fim de semana, seja sobre uma compra no mercado, seja sobre uma visita ao museu, etc. Cada aluno poderia circular pela sala para descobrir essas informações do colega e do professor, ou poderia simplesmente entrevistar um só colega e relatar o resultado à sala e, em casa, escrever um texto jornalístico em que contaria suas descobertas sobre os colegas - oportunidade mais formal em que a forma simples do mais-que-perfeito poderia ser usada, além de se treinar o uso da linguagem jornalística, que exige determinadas escolhas lingüísticas em detrimento de outras mais informais utilizadas na fala.

Como recurso complementar ao livro didático, vídeos também poderiam ser utilizados para a descrição das diversas situações que se apresentam diante do aluno, desde que preparados de antemão pelo professor, ou pelo próprio autor do método, com as perguntas certas no tempo que se deseja treinar.

\section{No Avenida Brasil 1 o Pretérito-mais-que-Perfeito Composto do Indicativo} (tinha feito) e o Simples (fizera) são introduzidos simultaneamente na unidade 10 da obra sob a forma de tabelas de conjugação.

Em seguida vem uma explicação sobre o uso do composto em forma de uma linha do tempo que indica a localização dos fatos no composto como anterior aos fatos no pretérito perfeito e no imperfeito, com exemplos como 'ontem eu saí de casa às 9h. Ele telefonou às 10h. Eu já tinha saído quando ele telefonou' (Avenida Brasil 1, p.101), seguidos de um exercício em que o aluno precisa ligar colunas para fazer frases e assim conjugar os verbos nos tempos sugeridos. 
O Mais-que-Perfeito Simples vem seguido de uma explicação sobre o seu uso, indicando que esse tempo é encontrado em textos escritos e que, na linguagem falada, usa-se o composto.

Em seguida, aparece um trecho do romance Gabriela Cravo e Canela de Jorge Amado, em que vários dos verbos estão no mais-que-perfeito simples. Pede-se, então, que o aluno leia o texto, sublinhe os verbos nessa forma e, em seguida, reescreva o texto substituindo a forma simples pela forma composta.

O uso de material autêntico (um trecho de um romance, no caso) para uma atividade relacionada à nova estrutura ensinada é bastante louvável, especialmente porque se trata principalmente de um autor traduzido em vários idiomas mundo afora. Além disso, cria-se a oportunidade de ampliação vocabular, tanto de novas palavras quanto de expressões idiomáticas como 'num abrir e fechar de olhos', por exemplo.

O Fala Brasil introduz as duas formas do Pretérito-mais-que-perfeito (fizera / tinha feito) em unidades diferentes - o mais-que-perfeito simples na unidade 11 , e o composto, na unidade 9 .

Apresentam-se duas linhas do tempo na unidade 9, uma comparando passado e presente, e a outra comparando duas ações no passado, indicando, em seguida, que a ação anterior à outra no passado precisa ser expressa pelo uso do Mais-que-Perfeito (no caso, o composto).

Há ainda alguns exemplos ilustrativos dessa diferença: 'eu não fui ao restaurante com eles porque já tinha jantando'; 'ela não comprou o jornal porque já o tinha lido no escritório'; 'nós não falamos com ele porque, quando chegamos lá, ele já tinha saído' (Fala Brasil, p. 127), seguidos de uma explicação sobre a formação do particípio passado para as três conjugações (-ar, -er, -ir), e de outra sobre a formação do Maisque-Perfeito Composto (tinha + particípio).

Depois dessas explicações, seguem alguns diálogos em que se utiliza a estrutura nova, um exercício de preenchimento de lacunas para treinar-se a conjugação verbal e uma última explicação sobre a possibilidade de se usar também o verbo 'haver' como auxiliar de tempos compostos. Os autores aproveitam a oportunidade para introduzir o verbo 'andar' seguido de particípio, mas sem esclarecer a equivalência dessa estrutura com o perfeito composto (ando cansado $=$ tenho andado cansado). 
O Pretérito-mais-que-Perfeito Simples é introduzido por meio de uma comparação estrutural desse tempo com o composto, seguida de uma explicação sobre o uso da forma simples somente na linguagem escrita, e de outra explicação sobre a formação de tal tempo que apresenta algumas lacunas para que o aluno as preencha com os verbos conjugados. Há ainda uma tabela de conjugação, exercícios baseados na tabela e outro para substituição da forma simples pela composta.

A exemplo do Avenida Brasil 1, material autêntico poderia ter sido utilizado aqui para uma melhor contextualização da estrutura exposta, mesmo que fosse para identificar os verbos no mais-que-perfeito simples. Além disso, atividades mais interativas e mais relevantes também não são propostas pela obra, deixando a cargo do professor completar essa grande lacuna do método.

É louvável a explicação sobre o uso do Pretérito-mais-que-Perfeito Simples e Composto no Fala Brasil, mas, por outro lado, a falta de propostas para atividades interativas e mais significativas para o aluno compromete bastante, a nosso ver, a sedimentação dessas estruturas, já que não traz a possibilidade de situações-problema a serem resolvidas pelo aluno (como propõe NEVES, 1997) - assim, o que é explicado tão bem pode ser esquecido se não for vivenciado por meio dessas situações.

\subsubsection{O Futuro do Presente e o Futuro do Pretérito Compostos do Indicativo}

O Futuro do Presente Composto (terei feito) e o Futuro do Pretérito Composto (teria feito) são introduzidos no Falar...Ler...Escrever... por uma pequena explicação sobre o uso de cada tempo ("O Futuro do Presente Composto expressa uma ação terminada em algum ponto do futuro; 'O Futuro do Pretérito Composto indica uma ação que poderia ter acontecido no passado" - Falar...Ler...Escrever..., p. 232), seguida de exercícios estruturais com frases soltas, para o treino da conjugação verbal.

Uma outra atividade mais 'livre' pede ao aluno que pense nele daqui a 5 anos, seguida da pergunta 'o que você terá feito lá?'. A mesma coisa acontece com o Futuro do Pretérito Composto, ou seja, exercícios estruturais, com a exceção de duas atividades que pedem ao aluno que dê 5 ações para cada situação (ontem estava chovendo, mas com um belo dia de sol, o que você teria feito?; 'o que você teria feito 
de forma diferente em relação à sua família, ao seu trabalho, ao tipo de vida que você leva?').

Em seguida, uma tentativa de contextualização é feita por meio de um texto que descreve uma viagem ideal para as férias. Dizemos 'tentativa', porque, na verdade, as estruturas introduzidas na unidade são utilizadas somente duas vezes em um único parágrafo: "Se você tivesse planejado todos os passos da viagem, com certeza não teria tido nenhuma dificuldade" (Falar...Ler...Escrever..., p. 236). Por não se tratar de um texto autêntico no sentido empregado por Coste, apud Franzoni (1992) (a fonte não é identificada), poder-se-ia ter criado algo mais voltado ao uso dos tempos compostos, ainda que mantendo os demais tempos utilizados no texto, já que, no dia-a-dia, é muito difícil encontrar situações que só usam de tempos compostos.

Atividades interativas não são propostas aqui pelo método, além de não serem levados em consideração quesitos como materiais autênticos, pequenos desafios, situações-problema, para citar somente alguns. Por outro lado, é mérito da obra pelo menos levar em conta a existência do Futuro do Pretérito Composto e do Futuro do Presente Composto e tentar esclarecer o seu uso, já que no Avenida Brasil e no Fala Brasil tais tempos não são sequer mencionados.

\subsubsection{Os tempos compostos do subjuntivo}

A exceção do Bem-Vindo!, cujos tempos compostos são encontrados em um única tabela (já transcrita no item anterior), descreveremos aqui como o Falar...Ler...Escrever, o Avenida Brasil e o Fala Brasil Introduzem e sedimentam os tempos compostos do subjuntivo, além de oferecer nossas sugestões de acordo com nossa base teórica e nossa experiência.

Esses tempos são introduzidos no Falar...Ler...Escrever... por meio de uma tabela de conjugação (Perfeito - que eu tenha morado; Mais-que-Perfeito - se eu tivesse morado; Futuro Composto - quando eu tiver morado) seguida por uma explicação quanto ao seu emprego, reproduzida a seguir: 
"Emprego

Os tempos compostos do subjuntivo indicam ações terminadas. Eles são usados nas mesmas condições dos tempos simples do subjuntivo. Exemplo:

Duvido que ele tenha vendido a casa.

Duvidei que ele tivesse vendido a casa.

suas ações.

Ele comprará uma fazenda quando tiver vendido

Os tempos compostos do Modo subjuntivo, perfeito (tenha falado), maisque-perfeito (tivesse falado) e futuro composto (tiver falado) correspondem aos mesmos tempos do Modo Indicativo. Eles são introduzidos apenas porque a estrutura da frase exige o subjuntivo. Se não fosse assim, o indicativo seria usado.

Ele foi?

Duvido que tenha ido.

Ele disse que tinha tido problemas.

Eu sei. Lamentei que ele tivesse tido problemas.

Até lá terei terminado isto.

Ótimo. Daremos uma festa quando você tiver terminado." (Falar...Ler...Escrever..., p. 240)

Essa explicação é seguida por exercícios de perguntas e respostas, cujo exemplo sugere que tais respostas sejam dadas no perfeito do subjuntivo ('Quem disse isso? - Eu não disse. Talvez ele tenha dito.').

A próxima atividade, também de perguntas e respostas seguindo o mesmo esquema da anterior, usa como ilustração documentos emitidos no Brasil (Cédula de Identidade do Estrangeiro, CIC, Carteira Nacional de Habilitação, RG) infelizmente pouco explorada, deixando talvez a possibilidade de o professor fazer essa exploração enquanto procura utilizar as estruturas em enfoque.

A próxima atividade enfoca o Mais-que-Perfeito do Subjuntivo e pede que o aluno transforme frases do Perfeito para o Mais-que-Perfeito, utilizando as estruturas sugeridas por um exemplo ('embora eu lhe tivesse escrito cartas...'), seguida de outra atividade de transformação de frases, do indicativo para o subjuntivo, para que o aluno complete as respostas de acordo com outro exemplo ('Você disse aquilo. Lamentei que você tivesse dito aquilo').

O ponto positivo de tal atividade é o esclarecimento prático de quando utilizar o tempo composto no subjuntivo por meio de frases que trazem expressões que exigem tal modo (lamentei que, tive medo que, etc.). A última atividade voltada ao mais-queperfeito pede novamente que o aluno complete frases utilizando esse tempo verbal ('com tempo, eu o teria convencido = se eu tivesse tido tempo, eu o teria convencido'). 
Ao Futuro Composto do Subjuntivo, são dedicadas quatro atividades não muito diferentes das anteriores, exceto pela última que traz ilustrações do interior de uma casa e, para cada ilustração, repete a seguinte frase: 'Nossa casa está pronta. Quando poderemos mudar?', ao que o aluno precisa responder de acordo com as figuras que vê (assim que os pintores tiverem pintado a casa; logo que a luz tiver sido ligada; etc.).

A última atividade sobre o tema 'tempos compostos do subjuntivo' no Falar...Ler...Escrever... é de preenchimento de lacunas, na qual os três tempos aparecem todos juntos - o aluno, de acordo com a estrutura da frase, precisa determinar qual o tempo mais adequado.

Acreditamos que as autoras do Falar...Ler...Escrever... tenham sido bem cuidadosas quanto à introdução dos compostos do subjuntivo, além de tentar esclarecer os diversos usos desse tempo. Comparativamente, de nosso corpus, é o Falar...Ler...Escrever... que oferece maior quantidade de atividades voltadas aos tempos compostos do subjuntivo, apesar de serem mais estruturais e pouco contextualizadas em sua maioria.

Outras atividades mais indutivas e interativas poderiam ser propostas aqui, explorando até o material autêntico disponível no próprio LD, ou mesmo sugerindo outras situações-problema relativas ao ambiente de trabalho, à vida cotidiana do aluno, ao quadro político do país, entre inúmeros outros temas a serem explorados em atividades em duplas ou em grupo.

No Avenida Brasil 2, os tempos compostos do subjuntivo são introduzidos em unidades diferentes, juntamente com as formas simples. O Perfeito do Subjuntivo é apresentado na lição 3, ao mesmo tempo em que se introduz o Presente do Subjuntivo, ambos ligados a estruturas frasais que utilizam determinadas conjunções que exigem tal modo. Reproduzimos o quadro explicativo da página 29 a seguir: 


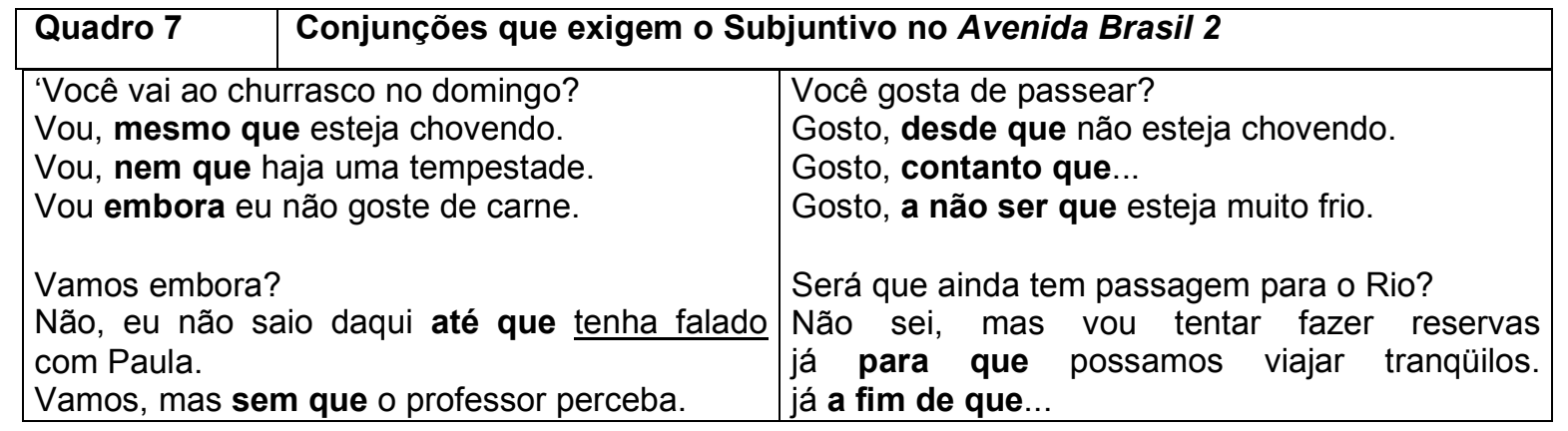

Há também um outro quadro que associa o subjuntivo a frases indefinidas que utilizam 'alguém que', 'alguma coisa que', 'algo que', etc. ('você conhece alguém que fale dinamarquês?' - Avenida Brasil 2, p. 30).

Essas explicações vêm seguidas de exercícios em forma de coluna para formação de frases e discussão com o professor sobre os significados das conjunções expostas, a serem utilizadas pelo aluno ('vou ficar aqui, mesmo que ele vá embora'), além de uma atividade de preenchimento de lacunas em que o aluno deverá conjugar os verbos sugeridos entre parênteses.

O Mais-que-Perfeito do Subjuntivo é introduzido nessa obra por meio de um quadro explicativo na lição 4, logo depois de o Imperfeito do Subjuntivo ter sido introduzido e sedimentado. Trata-se na verdade de vários exemplos que utilizam tal tempo ('ontem eu ainda duvidava que ele tivesse recebido minha carta anteontem'; 'ele duvidou que eu tivesse trabalhado ontem; etc.), seguidos de um exercício de preenchimento de lacunas no qual o aluno conjuga os verbos sugeridos entre parênteses no mais-que-perfeito do subjuntivo. Há ainda uma atividade mais interativa que pede ao aluno que fale com um colega e responda às perguntas desse colega utilizando 'talvez' ou 'ela duvidou que...'

O Futuro Composto do Subjuntivo também é introduzido por um quadro de exemplos, ao lado do verbo 'morar' conjugado no futuro simples do subjuntivo (quando eu morar) para eu/você/ele/ela e plurais ('só sairei do escritório quando tiver terminado meu trabalho'), quadro esse seguido de um exercício de perguntas e respostas, cujos verbos e complementos vêm sugeridos entre parênteses.

A sedimentação desse tempo pára por aqui, mas poderia ter sido mais bem feita em atividades outras, tanto em grupo quanto em dupla, explorando recursos audiovisuais (material autêntico) ou mesmo por exercícios de conjugação em cadeia, 
como: 'Hoje, quando você tiver terminado sua tarefa, o que vai fazer?' - 'Vou sair com os amigos' - 'E quando você tiver voltado para casa, o que vai fazer?' - 'Vou dormir'; etc., para deixar mais claro o uso desse tempo como recurso que passa a noção de ação acabada no futuro.

O recurso da entrevista poderia ser utilizado novamente, na qual o aluno tenta descobrir de seu colega quais são seus planos para o futuro, depois que dominar o português, por exemplo. Ou mesmo nos próximos 5 ou 10 anos.

A entrevista poderia partir tembém de um texto sobre a situação econômica do País, ou sobre eventos públicos como o carnaval, por exemplo, e, a partir dele, perguntas poderiam ser sugeridas sobre o futuro - $\mathrm{o}$ aluno usaria tais perguntas para entrevistar o colega e depois reportaria suas descobertas à sala ao mesmo tempo em que expressa sua própria opinião sobre o assunto assim como elementos de sua própria cultura. Trabalhar-se-iam aqui tanto a forma quanto o uso do Futuro Composto do Subjuntivo, além de ocorrer a intensa negociação de sentidos de que nos fala Germain (1996), a abordagem de outras nuances do aluno de que nos fala Santos (2003), para citar somente alguns dos quesitos vindos de nossa base teórica. 


\section{Introdução dos verbos 'ser' e 'ter' na série New Interchange}

Como informamos na introdução do presente trabalho, optamos por um método de ensino de língua estrangeira, no caso do inglês, a título de mais sugestões de como os livros didáticos de português para estrangeiros poderiam melhorar sua forma de introduzir e sedimentar a conjugação dos verbos 'ser' e 'ter'.

A opção pela série New Interchange baseia-se tanto em nossa experiência bastante positiva com seu uso quanto no fato de ela responder bem a muitos dos quesitos de nossa base teórica, como o uso de assuntos relevantes e contemporâneos (globalização, artes, costumes nos Estados Unidos e em outros países, etc.), expansão vocabular, exercícios para treinar a pronúncia e a prosódia, atividades interativas, além de alguns exercícios mais voltados aos aspectos gramaticais enfocados em cada unidade - o 'grammar focus'.

De base comunicativa (conforme a definição dessa abordagem oferecida por Firth, apud GALLOWAY, 1993) e voltada ao público jovem e adulto de qualquer língua, sua filosofia subjacente, segundo o autor da série, é

(...)learning a second or foreign language is more rewarding, meaningful, and effective when the language is used for authentic communication. Throughout New Interchange, students are presented with natural and useful language. In addition, students have the opportunity to personalize the language they learn, make use of their own knowledge and experiences, and express their ideas and opinions" (New Interchange 3, teacher's manual, p.V) ${ }^{34}$

Essa filosofia subjacente de que nos fala o autor do New Interchange, a qual considera o aluno alguém que possui conhecimentos prévios, opinião própria, além de aprender por meio da interação com seus pares ou com o grupo todo na sala de aula, demonstra uma proximidade muito grande com a definição de sujeito no paradigma complexo, ou seja, o sujeito é visto nesse paradigma como uma complexidade "que se constrói mobilizando dimensões mentais e corporais por meio da comunicação com outra complexidade, que é o mundo exterior" (SANTOS, 2003, p. 19).

\footnotetext{
${ }^{34}(\ldots)$ aprender uma segunda língua ou uma língua estrangeira é mais recompensador, significativo e efetivo quando a língua é usada para a comunicação autêntica. Em todo o New Interchange, é apresentada ao aluno uma linguagem natural e útil. Além disso, o aluno tem a oportunidade de personalizar a língua que ele aprende, fazer uso de seu próprio conhecimento e experiência e expressar suas idéias e opiniões.
} 
É por meio dessa comunicação ou interação com o outro que o sujeito se faz como tal, porém mantém sua integridade e sua autonomia, já que depende de seus conhecimentos e de suas experiências anteriores para (re)construir seu conhecimento da língua-alvo, e é dono de capacidade criativa, de um estilo de aprendizagem próprio e de capacidade para formular estratégias para alcançar seus objetivos e de autoorganização.

A série toda ${ }^{35}$ segue uma disposição padrão de atividades de diferentes naturezas, trazendo ao aluno uma certa sensação de segurança ${ }^{36}$ : cada unidade sempre começa com o 'snap shot' - uma tomada rápida sobre o tema a ser abordado por meio de expansão vocabular, gráficos, dados sobre população, sobre hábitos de consumo, entre outros. Em seguida vem um diálogo situacional, seguido pelo 'grammar focus' já citado.

Atividades de leitura, de escuta e de escrita são distribuídas ao longo da unidade, sendo a última delas a leitura de um texto um pouco mais longo, geralmente seguido por perguntas de interpretação de texto e de alguma atividade que convida o aluno a dar a sua opinião ou a discutir sobre o conteúdo do texto.

Os diálogos e os textos estão todos gravados no CD (vendido separadamente), além de outras atividades de escuta como conversas, entrevistas, opiniões. A série inclui o livro do aluno, o livro de exercícios (workbook), o livro do professor (este com o passo a passo de como deve ser dada a aula, além da transcrição das atividades de escuta do CD) e o livro de atividades extras (resource book) fotocopiável, a ser utilizado pelo professor. Neste livro vêm atividades a serem executadas em sala, atividades essas que desenvolvem o vocabulário, a escuta e as estruturas gramaticais por meio de 'flash cards', exercícios mais estruturais e de múltipla escolha para uso do CD.

\footnotetext{
${ }^{35}$ São ao todo 4 níveis: o New Interchange Intro e os New Interchange 1, 2 e 3, cobrindo desde o nível introdutório até o intermediário. $\mathrm{O}$ autor esclarece que cada nível pode ser cumprido em 70 a 120 horas/aula.

${ }^{36}$ Tal disposição padrão de atividades nos livros da série New Interchange vai ao encontro do que Morin prega sobre o aprendizado: "(...) o conhecimento deve dispor de certezas (do fixo, do estável, do repetitivo, do predizível nos quais a informação pode revelar a sua mensagem) para enfrentar e resolver a incerteza (...)" (MORIN, 1996, p. 63).
} 


\subsection{O verbo 'ser'}

Quanto à introdução e sedimentação do verbo 'ser' (to be), observamos já no índice de assuntos do New Interchange Intro, primeiro livro da série voltado a iniciantes, que ela apresenta o verbo 'to be' (ser/estar) em três unidades iniciais, cujos títulos são: 'It's nice to meet you' (greetings, names, titles, address, telephone numbers) ${ }^{37}$; 'What's this?' (possessions, classroom objects, persontal items, locations in a room) ${ }^{38}$; 'Where are you from?' (cities, countries, regions; adjectives of personality; age) ${ }^{39}$.

Nas unidades 4 e 5, o presente contínuo (Present Progressive) é introduzido aproveitando o gancho das três primeiras unidades que trazem o 'to be', já que a formação do Present Progressive necessita do 'to be' como seu verbo auxiliar.

A unidade 1 inicia com um diálogo de apresentação entre dois colegas (Michael Parker e Jennifer Yang), seguido de uma tabela com os nomes próprios mais comuns nos Estados Unidos (Christopher, David, Jennifer, etc.). Em seguida, vem o 'grammar focus', no qual o verbo e as expressões introduzidas pelo primeiro diálogo são rapidamente trabalhadas. Há nessa atividade (que na verdade se divide em dois exercícios distintos dentro da unidade) uma tabela de conjugação do verbo 'to be' em todas as pessoas gramaticais, com frases soltas porém de certa forma ligadas aos tópicos enfocados pela unidade (apresentações, localização, etc.).

Em cada uma das 3 unidades que trabalham o 'to be', há ao todo 10 a 11 atividades muito bem ilustradas com desenhos, fotos e quadrinhos, que trabalham a conjugação e o uso desse verbo. O vocabulário é apresentado com abundância de imagens, enfocando sempre os objetos da sala de aula ou do universo de trabalho (calculator, cell phone, eraser, English book), além de frases cada vez mais complexas nos diálogos e nos textos no decorrer das unidades, e de exercícios de preencher e de escuta, em tentativa louvável de relacionar o conteúdo ensinado com a realidade do aluno, como no exemplo da atividade 3 , unidade 3 , que traz perguntas como: Is your language English? Are you Brazilian? ('a sua lingual é o inglês?'; 'você é brasileiro?'), etc.

\footnotetext{
37 'Prazer em conhecê-lo' (cumprimentos, nomes, títulos, endereços, números de telefone)

38 'O que é isso?' (posse, objetos da sala de aula, itens pessoais, localizações em uma sala)

39 'De onde você é?' (cidades, países, regiões; adjetivos de personalidade; idade)
} 
O livro de exercícios oferece o mesmo número de atividades que o livro do aluno, fazendo sempre a correspondência de conteúdos (atividade 1: apresentações, tanto no livro do aluno quanto no de exercícios, por exemplo). As ilustrações neste caderno não são coloridas mas ilustram claramente cada atividade.

$\mathrm{Na}$ unidade 3 do 'resource book' há os flash cards nos quais estão perguntas em metade deles e respostas na outra metade. Uma cópia deve ser feita pelo professor, assim como a separação dos cartões a serem distribuídos entre os alunos com o objetivo de interação (o aluno com o cartão-resposta 'My name is Jill' - meu nome é Jill - deve responder ao aluno com o cartão-pergunta 'What's your name?' - qual o seu nome?, por exemplo), o que vem ao encontro do que Galloway, 1993 sugere como atividade interativa.

\subsubsection{A voz passiva}

A voz passiva é introduzida no segundo e no terceiro livros do New Interchange, sendo um só capítulo naquele (Passive with 'by' (simple past); passive without 'by' passiva com 'by' (passado simples) e passiva sem 'by'), e dois capítulos neste (passive in the present continuous and present perfect; The passive to describe process with 'be' and modals - passiva no presente contínuo e no present perfect. A passiva para descrever processo com 'be' e com modais).

Como o conteúdo gramatical de unidades anteriores é retomado em cada unidade, amplificando o uso desse item, optamos por analisar somente o último que trata da voz passiva, ou seja, a unidade 14 do livro 3, cujo tema é 'behind the scenes' nos bastidores.

A unidade toda tem como pano de fundo a indústria cinematográfica e usa tal assunto para apresentar a voz passiva em seus diversos usos, seja com ou sem 'by' (por, pelo, pela, pelos, pelas), no presente contínuo e no present perfect.

A unidade começa com alguns fatos sobre a história do cinema, com datas e respectivos acontecimentos mais relevantes (1889 - Motion-picture câmera; 1903 - 
Silent narrative film 'The Great Train Robbery'; etc.) ${ }^{40}$ seguidos de algumas perguntas sobre a experiência pessoal do aluno: se ele já viu algum dos filmes citados, se já viu filmes mudos ou em 3-D, se há filmes feitos no país do aluno.

Na próxima atividade encontra-se um diálogo impresso, também disponível no cd que acompanha o livro, no qual dois amigos conversam sobre como se faz um filme usando frases na voz passiva ('cada cena não é filmada uma só vez', 'quantas tomadas são feitas', etc.).

A segunda parte da atividade consiste em uma escuta da qual o aluno precisa obter a resposta para a pergunta 'que mais faz o trabalho em filmagem algo difícil?'. A seguir, o 'grammar focus' explica que a voz passiva é usada para descrever como algo é feito ou usado, com exemplos em forma de frases soltas, porém contextualizadas no tema da unidade.

O exercício seguinte consiste em pôr em ordem diversos parágrafos que falam de como são feitos os filmes, logo depois de completar as lacunas com os verbos sugeridos entre parênteses, a serem conjugados na voz passiva.

Outra atividade de escuta é proposta na qual o aluno precisa escrever duas coisas que ele aprendeu sobre o ofício de produtor de filmes a partir do que ouviu na gravação.

A próxima atividade é feita em pares, na qual há quadrinhos misturados que perfazem duas histórias diferentes, descrevendo as etapas de uma performance teatral e da elaboração de um jornal - os alunos devem pôr os quadrinhos na ordem e descrever pelo menos uma das histórias utilizando verbos e substantivos sugeridos pelo autor para cada uma delas (actors, costumes, play, design, etc. ${ }^{41}$, além de escolher um terceiro evento de uma pequena lista (a fashion show, a rock concert, a TV sitcom $)^{42}$ e escrever como imaginam que seja preparar tal evento.

Por fim, uma atividade voltada à escrita em que o aluno precisa escolher um dos eventos/histórias da atividade anterior e escrever 5 tópicos imaginados por ele - há um texto-base falando sobre um show de mágica que pode ser usado de modelo. Em duplas, o aluno lê o seu texto e recebe sugestões do colega para melhorá-lo.

\footnotetext{
401889 - câmera de filmagem; 1903 - o filme mudo "O assalto ao trem pagador"; etc.

${ }^{41}$ Atores, figurinos, peça, design, etc.

${ }^{42}$ Show de moda, um concerto de rock, uma comédia de costumes.
} 
Dessa forma, as habilidades comunicativas são todas treinadas nesta unidade do New Interchange 3, além de uma grande variedade de tipos de atividades ter sido oferecida ao aluno, acompanhadas de material autêntico (fotos, dados históricos, etc.), dentro de um tema se não totalmente relevante, pelo menos interessante, já que faz parte do dia-a-dia ou dos interesses de um aluno médio (quem não assiste a um filme, a um show ou a uma peça teatral de vez em quando?).

Além disso, a teoria do input compreensível é levada em conta quando pequenos desafios são oferecidos ao aluno, além de inputs anteriores serem reapresentados (o uso do 'by', por exemplo) em novos contextos, o que respeita a noção de circularidade da construção do conhecimento pregada pelo paradigma complexo .

\subsection{O verbo 'ter'}

O equivalente ao nosso 'ter', o 'to have', é introduzido na unidade 6 do New Interchange Intro, junto a outros verbos regulares e irregulares no presente. Apesar de irregular, o verbo 'to have' tem somente duas formas no presente afirmativo: 'have' para as primeiras e segundas pessoas e para a terceira pessoa do plural, e 'has' para as terceiras pessoas do singular. A apresentação de sua conjugação é feita no 'grammar focus' em forma de frases soltas, porém relacionadas ao tema do primeiro diálogo da unidade, seguidas de pequenos diálogos em que o aluno precisa preencher lacunas optando por uma ou outra forma do verbo (have/has).

Há ainda uma atividade voltada à pronúncia de tal verbo, além de outra escrita, em que o aluno precisa escrever cinco frases sobre sua própria família em um pedaço de papel ('moro com meus pais, tenho duas irmãs...), para, posteriormente, serem lidos em voz alta por um dos colegas para o que os demais tentem adivinhar de quem é a família descrita.

A forma interrogativa do verbo (Does he have...? Do you have...?) é introduzida em outro grammar focus na mesma unidade, e a negativa (don't/doesn't have), em um grammar focus somente na unidade seguinte.

Há ainda as atividades de escuta em que o aluno ouve uma gravação de quatro conversas de pessoas que falam sobre seus hábitos e rotinas para que ele aponte em 
respostas de múltipla escolha, frases que correspondam ao conteúdo das conversas ouvidas. Em outra atividade de escuta, o aluno ouve declarações de quatro pessoas, cujas fotos estão disponíveis no LD, falando sobre suas rotinas também, mas desta vez o aluno precisa anotar o que cada uma delas faz, em forma de frases completas.

A técnica de pesquisa/entrevista entre os alunos é sugerida por uma atividade à parte em que o aluno tem de descobrir, por exemplo, quem toma café da manhã na cama ('has breakfast in bed'), quem tem bicicleta, quem usa jeans todos os dias, entre outras. Suas descobertas serão comentadas logo mais com os demais colegas, usando assim as terceiras pessoas do singular.

Destacamos um uso diferente do verbo 'ter' ou 'have' em inglês que é o de sinônimo de 'comer' e 'beber/tomar', quando seguido de substantivos que denotam comida ou bebida (to have coffee; to have fried chicken). O verbo 'have' como sinônimo de 'sentir' apontado por Gomes, s/d, para o 'ter' do português, também é usado em inglês, introduzido na unidade 12 que trata de problemas de saúde (have a headache/a sore throat/ the flu - ter dor de cabeça, dor de garganta, gripe).

Perguntas com os pronomes interrogativos 'o que' e 'quem' são feitas no final de três pequenos textos que falam, em primeira pessoa, da rotina de uma estudante, de um web-designer e de uma cantora de rock, a fim de treinar também as terceiras pessoas do singular ('who works on weekends?' - quem trabalha aos fins de semana?) além de pedir ao aluno que aponte uma coisa de que gosta e outra de que não gosta em relação às rotinas descritas no texto.

O pretérito de 'Have' (simple past) é introduzido de forma semelhante na unidade 14 do New Interchange Intro, além de vir sedimentado com outros verbos em dois textos no final da unidade que descrevem os fins de semana no início do século $X X$ comparados aos fins de semana de hoje: aqui encontramos o simple past como equivalente ao nosso Pretérito Imperfeito do Indicativo, já que é usado para descrições de hábitos no passado. Além disso, outro exercício à parte é sugerido em que o aluno faz diversas perguntas a um colega (se ele arrumava a cama quando criança e se continua arrumando agora, etc.) e depois comenta suas descobertas com outro colega.

Os exercícios do workbook (livro de exercícios) seguem o estilo do livro do aluno, ou seja, oferecem material autêntico como fotos (em preto e branco), gráficos, dados, 
etc., textos que contextualizam a estrutura enfocada e um pouco mais de exercícios de gramática para reforço.

\subsubsection{O verbo 'ter' como auxiliar - tempos compostos}

Antes de comentarmos sobre como o New Interchange aborda o tema 'tempos compostos', cabe-nos esclarecer que, em inglês, os tempos compostos formados por 'ter' (have/has) + particípio algumas vezes diferem em sentido e uso quando traduzidos para o português.

Segundo Beare (s/d), um bom exemplo dessa diferença ficaria por conta do Present Perfect, que usa o verbo 'ter' no presente como auxiliar, de forma similar ao português, mas que muitas vezes não transmite a mesma idéia: 'I have lost my keys', deve ser traduzido por 'perdi minhas chaves', porém com uma idéia de ligação ainda muito forte com o presente, especialmente no inglês britânico (eu as perdi e ainda não as encontrei, em contraste com o Simple Past, 'I lost my keys' - 'perdi minhas chaves' que, muitas vezes, pode dar a entender que as chaves já foram encontradas).

A maioria dos métodos de ensino do inglês, incluindo o New Interchange, demonstra uma grande preocupação em diferençar o Present Perfect do Simple Past por meio de tabelas comparativas de uso, sempre associando cada tempo a seus respectivos marcadores.

No segundo livro da série New Interchange, por exemplo, apresenta-se uma dessas tabelas no 'grammar focus' em que se associa o Present Perfect aos advérbios de tempo 'ever' (aqui traduzido como 'já') e 'never' ('nunca'): 'Have you ever seen a magic show?' (você já viu um show de mágica?), cuja resposta pressupõe o uso do auxiliar: 'Yes, I have' (sim, já vi) ou 'No, I haven't' (não, não vi). Quando se utilizam advérbios de tempo específico, porém, o uso do Simple Past torna-se obrigatório: 'I saw a magic show last year' (vi um show de mágica ano passado).

A parte final do livro 1 e algumas unidades do livro 2 da série New Interchange foram dedicadas ao Simple Past - somente na unidade 10 do livro 2 o Present Perfect é introduzido e, em seguida, comparado ao Simple Past. Fato que se repetirá no terceiro livro da série, mais uma vez associando o Present Perfect aos advérbios de tempo 
'ever' e 'never', porém em novos contextos, o que condiz com o paradigma complexo por tratar o conhecimento como rotativo, quando o que foi ensinado precisa ser retomado em situações diferentes para que seu conhecimento fique o mais completo e o mais fundamentado possível.

Os autores do Fala Brasil bem acertam quando contrastam o Perfeito Composto do Indicativo do Português (tenho estudado) com o Present Perfect Continuous (I have been studying) do inglês e não com o Present Perfect (I have studied), já que condiz com a descrição do uso desse tempo por Beare: "Use the present perfect continuous to express the duration of an activity that begins in the past and continues up to the present moment." (BEARE, s/d, s/p) ${ }^{43}$ - é esse o tempo que traz a noção de certeza de que uma ação iniciada no passado ainda continua no presente.

Como o New Interchange não aborda o Present Perfect Continuous, provavelmente por considerá-lo um tema para um curso de pós-intermediário (a série só cobre até o intermediário), vamos expor o que o método oferece então sobre o correspondente no inglês do Presente do Futuro Composto (Future Perfect), introduzido somente no último livro da série, aquele que cobre o nível intermediário.

O Future Perfect é introduzido na unidade 10 por meio de uma explicação e de exemplos na atividade 'grammar focus' reproduzidos parcialmente a seguir:

Use future perfect for actions that will be completed by a certain time in the future. Within 20 years, they will have found a way for us to get all the news through computers.By then, maybe even newspapers will have disappeared.' (New Interchange 3 , p. 63$)^{44}$

Em seguida, vem uma atividade de preenchimento de lacunas na qual o aluno precisa optar entre três formas de futuro de acordo com o sentido das frases, entre essas formas o Future Perfect, para conjugar corretamente os verbos entre parênteses.

\footnotetext{
${ }^{43}$ Use o present perfect continuous para expressar a duração de qualquer atividade que começa no passado e continua no presente.

${ }_{44}$ "Use o futuro perfeito para ações que serão completadas em um certo tempo no futuro: Dentro de 20 anos, terão descoberto uma forma de conseguirmos todas as nossas notícias via computador. Então, pode ser que mesmo os jornais tenham desaparecido".

Os outros tempos usados para expressar o futuro que vêm no mesmo quadro do Future Perfect no Interchange 3 são o Present Continuous, 'will', 'be going to' e o Future Continuous, este para ações em curso no futuro, e aqueles para eventos ou situações no futuro.
} 
A próxima atividade trata de um trabalho em grupo, no qual cada aluno lê um dos itens da atividade anterior e expressa sua opinião para a sala como forma de provocar um debate.

A atividade seguinte a essa enfoca a escuta, quando o aluno precisa ouvir algumas pessoas discutindo sobre o futuro de diversas áreas (trabalho, transporte, educação, saúde) nos próximos 50 anos e registrar quais serão essas mudanças, além de sugerir alguma outra mudança possível em cada área para discussão em grupo.

A próxima atividade traz uma série de perguntas sobre o futuro do aluno, cujas respostas deverão ser discutidas em grupo ('Diga três objetivos seus que terão sido alcançados dentro dos próximos cinco anos'; 'diga três coisas que você não terá feito nesse tempo'; 'de que forma você acha que terá mudado na época de sua aposentadoria?', New Interchange 3, p. 64).

A última atividade da unidade 10 é de leitura, na qual o aluno lê um texto sobre a 'aldeia global' que fala sobre globalização desde o final da segunda guerra mundial até as tecnologias de hoje, e termina com perguntas sobre o futuro. $\mathrm{O}$ aluno responde a perguntas de entendimento de texto e, em seguida, expressa sua opinião sobre as vantagens e desvantagens dessa 'aldeia global' e sobre outras possíveis mudanças que o mundo enfrentará no século 21 e quais dessas mudanças o aluno considera as mais sérias.

O equivalente ao nosso Mais-que-Perfeito Composto do Indicativo no sentido de ação anterior a outra no passado, o past perfect, é introduzido também no terceiro livro da série New Interchange, no meio da unidade 4, por meio de um diálogo reproduzido a seguir:

\footnotetext{
Brian: Someone stole my wallet last night!

Kate: Oh no! What happened?

Brian: Well, I was working out, and I had put my stuff in my locker, just like I always do. When I came back, someone had stolen my wallet. I guess l'd forgotten to lock the locker.

Kate: I'm sorry. That's terrible! Did you lose much money?

Brian: Only about $\$ 20$. But I lost my credit card and my driver's license. What a pain!
}

(New Interchange 3, p.23) $^{45}$

\footnotetext{
${ }^{45}$ Alguém roubou minha carteira ontem à noite! / Oh, não! O que aconteceu? / Bem, eu estava me exercitando, tinha posto minhas coisas no armário como sempre faço. Quando voltei, alguém tinha roubado minha carteira. Acho que esqueci de trancar o armário. / Sinto muito. Isso é terrível! Você perdeu muito dinheiro? / Somente uns $\$ 20$. Mas perdi meu cartão de crédito e minha carteira de motorista. Que dor de cabeça!
} 
Em seguida ao diálogo, vem uma atividade de escuta na qual o aluno ouve o restante da conversa em que Kate fala sobre uma ocasião em que foi assaltada. Depois, a atividade 'grammar focus' que utiliza as frases do próprio diálogo para ilustrar o exercício de preenchimento de lacunas em que o aluno precisa optar pela conjugação correta do verbo de acordo com a idéia de ação no passado, ação anterior a outra no passado ou de processo também no passado, para conjugar os verbos no simple past (did), no past perfect (had done) ou ainda no past continuous (was doing). $O$ interessante dessa atividade é que se pede ao aluno, além de preencher as lacunas, ligar as frases das duas colunas em que o exercício está disposto para contar histórias, adicionar uma frase a mais em cada história e, por fim, lê-las em forma de diálogo com um colega.

A próxima atividade trata de ampliação vocabular e pede ao aluno que ligue palavras da coluna A com sua explicação na coluna B para, em seguida, escolher três das palavras da coluna A para escrever frases completas utilizando o past perfect: 'Two people traveling separately, met while they were on vacation in China. Even though they had both lived in the same town their whole lives, they had never met before (coincidence),46 - O aluno é convidado a ler seus exemplos para um colega para que ele tente definir seus exemplos por meio de uma das palavras novas ensinadas nessa coluna (coincidence, disaster, emergency, etc.). ${ }^{47}$

A atividade seguinte é feita em duplas, na qual ambos os alunos precisam terminar uma história iniciada no livro - uma sobre uma viagem de avião (o avião tinha acabado de decolar quando o piloto anunciou...; o noticiário tinha acabado de terminar quando alguém tocou a campainha...).

A última atividade traz um texto sobre tablóides que registraram curiosidades sobre quatro países: Brasil, Estados Unidos, Quênia e México. Nos textos utiliza-se a estrutura apresentada na unidade, o past perfect, além de se pedir ao aluno que complete frases sobre o conteúdo desse texto, sendo esses inícios de frases escritos também no past perfect ('after people had rubbed the fish,...; After the firefighters had

\footnotetext{
${ }^{46}$ Duas pessoas viajando separadamente se conheceram quando estavam em férias na China. Mesmo tendo ambos vivido na mesma cidade por toda a sua vida, nunca tinham se encontrado antes (coincidência)).

${ }^{47}$ Coincidência, desastre, emergência, etc.
} 
given up hope, ....' - p. $25^{48}$ ), além de fazer perguntas ao aluno sobre o que ele pensa dos fatos relatados pelos tablóides, qual a história mais interessante, além de pedir que ele relate uma história impressionante que tenha ouvido.

O past perfect (had done) equivaletente ao nosso Mais-que-Perfeito Composto do Subjuntivo (tivesse feito) é introduzido na unidade 11 do último livro da série New Interchange como 'if clause in the past perfect'.

Tal tempo é introduzido pela atividade 'grammar focus' juntamente com 'should have + participle' como formas de expressar arrependimento sobre o passado ('I should have studied something more practical'; 'If I'd been sensible, I would have majored in ecomics', New Interchange 3, p. 69) ${ }^{49}$.

O aluno deve escrever finais para inícios de frases com 'should have', além de ligar duas colunas de inícios e finais de frases que utilizam as duas estruturas ensinadas e ainda adicionar suas próprias informações e compará-las com as dos colegas.

A atividade seguinte enfoca a prosódia, seguida de outra em que o aluno deve ouvir uma gravação e descobrir do que três personagens se arrependem e o porquê desse arrependimento.

Na última atividade da unidade 11, o aluno deve ler três pequenos textos sobre coisas de que três pessoas se arrependem e o que fariam se pudessem voltar no tempo. Há perguntas de entendimento de texto e, por fim, perguntas sobre a vida do aluno (o que você teria feito diferente?) e sobre o que o aluno entende da afirmação de psicólogos de que hoje as pessoas se arrependem mais facilmente, já que têm muitas escolhas e muito mais pressão do que tinham antigamente.

Observamos nessa forma de exposição tanto do future perfect quanto do past perfect feita no New Interchange, respostas a diversos quesitos do pensamento complexo e teorias afins, como atividades basicamente interativas e sempre contextualizadas, que enfocam o oral mas não deixam de lado a língua escrita, que trazem a cultura do aluno para a língua-alvo (como as curiosidades sobre quatro países, por exemplo), que oferecem situações-problema (de acordo com NEVES, 1997)

\footnotetext{
48 "Depois que as pessoas tinham esfregado o peixe...; depois que os bombeiros tinham desistido..."

49 'Eu deveria ter aprendido algo mais prático'; 'se eu tivesse sido razoável, eu teria me formado em economia'.
} 
e pequenos desafios (como sugerem GERMAIN, 1996 e TOMLISON, 2001), apesar de não apresentar muito material autêntico (fotos, gráficos, dados históricos) e de usar figuras e textos adaptados. Por outro lado, trazem adequação ao nível do aluno, variedade, entre outros.

Em comparação com os métodos de ensino de português como língua estrangeira, muito poderia ser aproveitado a título de exemplo dessa série para a apresentação dos verbos 'ser' e 'ter', com exceção de introduções muito passo a passo para hispano-falantes, como nos lembra Almeida Filho (2001).

A natureza das atividades oferecidas no New Interchange difere de uma para a outra, o que privilegia os mais diferentes tipos cognitivos (como sugerido por TOMLINSON, 2001), motivando o aluno (TOMLINSON, 2001 e SANTOS, 2003, sobre a motivação por meio da variedade e da pesquisa) e oferecendo, assim, mais chances de ele utilizar de maneira mais próxima do 'real' as estruturas enfocadas (no caso, os verbos 'to be' e 'to have'). 


\section{Uma última palavra sobre nosso corpus - a visão de aluno e do relacionamento professor/aluno}

Para que nossa análise dos LDs de PLE não ficasse de certa forma comprometida pela intenção dos autores desses LDs, deixamos para o fim deste trabalho a leitura dos manuais do professor que acompanham pelo menos três das obras analisadas, nos quais são descritos a metodologia adotada e seus objetivos, além do passo-a-passo para a utilização de suas unidades em sala de aula.

Essa leitura dos manuais do professor foi norteada pela pergunta: "como o método (entenda-se 'LD') vê o aluno e sua relação com o professor e os demais colegas (quando esses existem)?"

No manual do professor do Falar...Ler...Escrever..., por exemplo, oferece-se uma descrição das características do método em forma de itens. Vários desses itens nos dão pistas de como as autoras do método vêem o aluno: como alguém que precisa transmitir intenções de fala por meio de situações concretas do cotidiano; que precisa de um curso com ênfase comunicativa, apesar de nortear seu aprendizado pelas estruturas da língua, entre elas a conjugação verbal; como um ser autônomo, pois o método vem acompanhado por fitas cassete e por respostas aos exercícios do livrotexto.

Por outro lado, quando as autoras falam nos objetivos específicos do método, o fazem da seguinte maneira: "Dar aos estudantes estruturas gramaticais essenciais e vocabulário ativo, que permitam fácil e rápida comunicação desde as primeiras unidades" (Falar...Ler...Escrever..., Manual do Professor, pág. 11).

Se tentarmos ir um pouco mais além da interpretação do objetivo transcrito acima, observamos que as autoras utilizaram o verbo 'dar' ('dar aos estudantes...'), facilmente parafraseado por 'oferecer', 'fornecer', 'prover' - verbos que denotam uma certa passividade por parte do aluno, já que esse recebe algo do método, ou é provido de algo pelo método.

Poderíamos também parafrasear a palavra 'estruturas', utilizada acima, por 'regras' (em 'estruturas gramaticais essenciais'), mesmo que tais palavras não sejam exatamente sinônimas mas bem próximas em sentido contextualizado; além da palavra 'permitam', sinônima de 'possibilitem', 'autorizem'; e da palavra 'comunicação' que junta 
aos adjetivos 'fácil' e 'rápida', passa-nos a impressão de significar mera troca de informações entre interlocutores.

O resultado ficaria assim: "Prover os estudantes de regras gramaticais essenciais e vocabulário ativo, que possibilitem uma fácil e rápida troca de informações entre interlocutores desde as primeiras unidades".

Segundo Orlandi (2002), nossa sociedade se estrutura hierarquicamente, e nela a luta pelo poder é constante e se traduz nas mais diversas formas, especialmente na língua. Se nos lembrarmos de que a sistematização das estruturas gramaticais baseiase em relações assimétricas entre professor e aluno, sendo aquele detentor do conhecimento da língua-alvo, concluímos que as autoras transmitem uma visão estruturalista da língua, na qual o principal enfoque é a gramática, seguida pelo vocabulário amplo. Essa visão supõe que a comunicação é alcançada a partir do ensino da estrutura, e que a relação professor - aluno é de 'cima para baixo', já que o aluno precisa ser treinado / adestrado a usar as estruturas da língua para reproduzi-las corretamente.

Nesse ponto, não encontramos contradição entre nossa análise do objetivo específico da obra e como as autoras definem a metodologia adotada, já que a chamam de "método estrutural-comunicativo" (Falar...Ler...Escrever..., última capa do livro-texto).

Já na segunda obra analisada pelo presente trabalho, o Avenida Brasil, algo um tanto diferente da concepção de língua do Falar...Ler...Escrever... é encontrado: o manual do professor traz o seguinte comentário: "A concepção didática de Avenida Brasil abre espaço para aspectos comunicativos, estruturais e interculturais, respeitando processos de aprendizado individuais" (Manual do Professor do Avenida Brasil, p.8).

Se tomarmos a expressão utilizada pelos autores, 'abre espaço', podemos pressupor que não havia espaço para esses aspectos em LDs outros disponíveis para os alunos. E tal espaço se abriu para 'aspectos comunicativos, estruturais e interculturais' - enumeração que coloca em um mesmo nível tais aspectos, coisa que provavelmente não acontecia nos demais métodos de LPE até então (o manual do professor do Avenida Brasil é de 1992). 
A partir da descrição da metodologia adotada, percebemos que o aluno é visto pelos autores como alguém provido de autonomia e opinião própria (aspectos comunicativos), que traz sua cultura para a sala de aula (aspectos interculturais), que interage em relação simétrica com colegas e professor (aspectos comunicativos), mas que também precisa de exercícios de automatização das estruturas ensinadas (aspectos estruturais).

A gramática, porém, "não é meta, mas auxílio no aprendizado. A grande maioria dos alunos adultos tem necessidade dela como organizador racional da língua e como fonte à qual recorrer em momentos de dúvida" (Manual do professor do Avenida Brasil, p. 12) - visão totalmente condizente com o que van Passel (1983) comenta sobre a necessidade de regras práticas que o aluno adulto possui.

O manual do professor da terceira obra analisada, o Bem-Vindo!, pouco nos oferece de visão da metodologia adotada, exceto o passo-a-passo de utilização de cada uma das unidades que compõem a obra. Optamos então por observar o que a apresentação do livro-texto (o livro do aluno) tem a dizer.

No último parágrafo dessa apresentação, lemos o seguinte: “(...) livro elaborado especialmente para suprir a grande necessidade de um material dinâmico e interativo cujo foco central é a comunicação" (Bem-Vindo!, apresentação. Grifo nosso).

Pressupomos, a partir desse trecho, que outros materiais disponíveis no mercado não suprem essa necessidade de um material dinâmico e interativo, o que nos remete a um contexto de suposta demanda por parte do público estrangeiro por esse tipo de material. Público esse que aprende a nova língua de forma dinâmica, por meio da interação, seja com o professor, seja com os colegas, logo em uma relação simétrica com eles.

Além disso, observamos o uso do verbo 'suprir' no trecho citado, sinônimo de 'prover', 'fornecer' - palavras ligadas ao mundo capitalista, da produção, no qual há demanda/necessidade e oferta de acordo com essa demanda, ou vice-versa, quando a oferta cria uma demanda/necessidade por meio da propaganda.

Ou seja, tal LD talvez tenha sido concebido para ser 'consumido' durante a aquisição da língua pelo aluno, como um produto da sociedade capitalista em que foi elaborado. Logo ele encara o aluno como um ser capitalista, parte dessa sociedade, com necessidades a serem supridas ou mesmo criadas por meio da propaganda, da 
mídia. Van Passel é quem nos alerta sobre o perigo de os alunos carregarem a idéia difundida por tal mídia sobre métodos miraculosos, que ensinam a língua-alvo em pouco tempo, idéia essa presente na mente de muitos dos alunos que procuram um curso de línguas.

Talvez os autores do Bem-Vindo! tentem realizar essa fantasia do aluno de aprender uma língua em tempo curto, oferecendo-lhe um método 'dinâmico e voltado para a comunicação', desde que tal aluno não seja um total iniciante e adote o estilo de aprendizado oferecido pela obra.

A quarta obra analisada, o Fala Brasil, não possui manual do professor sob a alegação de que "a acessibilidade de Fala Brasil dispensa o uso de um manual do professor" (Fala Brasil, apresentação).

$\mathrm{Na}$ introdução à obra, os autores afirmam que "o destaque do método é a Sistematização feita com base no uso efetivo da língua. Os Diálogos Dirigidos são o elo de ligação entre a simples capacidade de conjugar o verbo e a capacidade de utilizá-lo em situações práticas(...)" (Fala Brasil, apresentação).

A própria forma de grafar a palavra 'sistematização', com um 's' maiúsculo, chama nossa atenção para o que se diz ser a principal característica do LD: sistemática, metódica, ordenada. Em um mecanismo de antecipação, como afirma Orlandi (2002), os autores oferecem ao aluno algo aparentemente seguro porque sistemático - sempre da mesma forma, em ordem - para que esse aluno possa assimilar o uso da língua, seu caráter funcional.

Por outro lado, a palavra 'sistematização' pode denotar 'automatização' - idéia ligada ao uso intensivo de exercícios de repetição das estruturas da língua para automatizá-las. Interpretação essa plausível, já que nada se fala sobre atividades interativas nem situacionais, somente em 'Diálogos Dirigidos', ou seja, a prática dirigida das estruturas enfocadas, deixando de fora o imprevisível, a espontaneidade: o aluno é visto, então, como alguém a ser treinado no uso das estruturas da língua e não a adquiri-la por meio da interação social.

Por fim, vale ressaltar que pelo menos dois desses LDs propõem objetivos claros para o aluno ${ }^{50}$, além de uma carga horária sugerida para que esses objetivos sejam

\footnotetext{
${ }^{50}$ A necessidade de objetivos claros e de um tempo previamente determinado para alcançá-los por parte de alunos adultos, é apontada por van Passel (1983).
} 
alcançados: o Falar...Ler...Escrever... propõe-se a atender "(...) amplamente os objetivos do ICC - International Certificate Conference - quanto ao desenvolvimento das quatro áreas de competência comunicativa, dando ao aluno todas as condições para prestar os exames de Nível Elementar e de Certificado" (manual do professor, p. 12) em 290 horas de aula para alunos de potencial médio de aprendizagem, 190 horas para alunos de ótimo potencial, e 380 horas para alunos com dificuldade.

Já o Avenida Brasil propõe-se a levar o aluno a dominar um “(...)vocabulário de aproximadamente 2.000 palavras e expressões, da gramática fundamental e da ênfase em estratégias intencionais(...)" (manual do professor, p. 8), permitindo que o aluno atinja um nível básico de português em aproximadamente 150 aulas de 90 minutos (225 horas).

Segundo nossa base teórica, a língua não é somente gramática (estrutura) nem tampouco mero instrumento de comunicação (para passar ou receber informações), apesar de também ser isso tudo: a língua é interação, é a cultura do povo que a domina, é troca, é a concretização de pensamentos e sentimentos, entre muitas outras características.

O Paradigma Complexo vê o aluno como um sujeito ativo, que contribui muito com seu aprendizado; o vê como autônomo, capaz de formular e de testar suas próprias teorias em relação à língua que pretende aprender; complexo pois portador de inúmeras nuances e de diferentes estilos de aprendizagem; inserido em um contexto globalizado, especialmente por causa da internet.

Sua relação com o professor é bastante simétrica, pois há espaço para que o aluno traga sua cultura para a língua-alvo dentro da sala de aula; ele se sente valorizado e acolhido pelo professor, o que baixa seu filtro afetivo; o professor não é visto como fonte exclusiva do conhecimento, o que dá abertura à troca de papéis ${ }^{51}$, portanto a uma relação aberta para novas descobertas dentro e fora da sala de aula.

\footnotetext{
${ }^{51}$ Quando o aluno expressa sua cultura na língua-alvo, em sala de aula, trazendo sua experiência como sujeito sócio-histórico que é, portanto exercendo o papel de locutor e contribuindo ativamente com a construção de seu conhecimento da língua.
} 


\section{Conclusão}

Muito poderíamos falar sobre pontos importantes de nossa base teórica e o quanto cada livro didático de português para estrangeiros analisado aqui carrega ou não desses pontos ao introduzir os dois verbos focos deste trabalho.

Preferimos antes, porém, falar um pouco mais sobre como esse novo paradigma, o pensamento complexo e teorias afins, encara o indivíduo aprendiz de uma língua estrangeira (em nosso caso, do português), já que é este indivíduo, independentemente de sua nacionalidade, que compõe o público-alvo das quatro obras analisadas pelo presente trabalho.

O paradigma complexo pensa pela associação de conceitos até então separados e aparentemente antagônicos que em sua inter-relação geram figuras complexas existentes somente nessa associação. Tal paradigma surgiu quando entrou em crise a visão tradicional da ciência que acreditava na objetividade dos enunciados científicos e na lógica que se fundava nessa pretensa objetividade - a ciência então deixa de ser sinônimo de certeza para se tornar sinônimo de incerteza.

Tal ciência passa a ver o indivíduo como um ser muito mais do que lógica/razão - passa a vê-lo como um ser extremamente complexo, pois é social ao mesmo tempo em que é histórico, político e individual, dotado de nuances diversas como a emocional, a ética, a estética, para mencionar somente algumas.

Ele é alguém que tem consciência dos limites do seu conhecimento, sabe que seu conhecimento não é algo acabado mas um processo não linear em perene construção, é capaz de formular estratégias para expandi-lo, é autônomo, reflexivo e com visão de mundo.

Seu conhecimento se constrói de maneira circular (os conceitos são repensados em cada fase de sua vida, sempre relacionados aos novos contextos), e autônoma (já que é capaz de formar e testar suas próprias teorias, de ser flexível, de se manter íntegro) porém dependente do outro e de conhecimentos anteriores para construir seu conhecimento; interdisciplinarmente a exemplo do conceito de 'bricolagem' mencionado por Santos (2003); dependente de seu tipo cognitivo, de seus interesses, de sua carga cultural, enfim, das bases primeiras sobre as quais construiu o seu sentido de pertencimento a determinado grupo. 
Esse indivíduo só alcança a compreensão quando pode ver um objeto ou acontecimento em suas relações ou não-relações com outros objetos ou acontecimentos - o significado para ele vem de um feixe de relações, por isso a contextualização faz-se indispensável para que ele alcance o conhecimento. Tal indivíduo é razão e emoção, estratégia e senso estético, política e sociedade, tudo interagindo e ditando sua forma de ver o mundo, de expressar-se e de expressar esse mundo.

Mesmo a língua passa a ser encarada de forma mais abrangente sob a luz desse novo paradigma, pois o pensamento complexo a vê como um sistema de sistemas que possui um comportamento não linear, ou, para usar as palavras de Britto (1997), um mosaico formado por uma rede complicada de semelhanças, e as de Ilari (2001), uma imbricação de diferentes sistemas - uns sobrepostos aos outros, uns sofrendo influência dos outros e vice-versa, criando algo tão complexo, porque não possui comportamento linear, quanto a própria língua.

Para um indivíduo como o descrito acima, e para o ensino/aquisição de uma língua estrangeira - estes também processos não lineares ou um sistema de sistemas, uma só abordagem didática não seria suficiente para dar conta de toda a complexidade em jogo. Talvez privilegiar a abordagem comunicativa em livros didáticos não seja a resposta para todas as necessidades desse indivíduo, mas a nosso ver a mais próxima de nossa base teórica.

Por outro lado, outras abordagens são bem-vindas nos pontos em que a comunicativa falha, como nos lembra Tan (2004). Em outras palavras, tudo vale desde que o método não reduza o aprendiz a uma ou só algumas de suas dimensões - o LD não pode se ater somente à gramática ou somente a atividades situacionais e interativas, nem a atividades que induzam à 'decoreba', mas a um meio termo privilegiando sempre a comunicação, o uso adequado de acordo com as situações sociais e com os objetivos do aluno, o expressar-se corretamente mas sem a exigência de uma pronúncia perfeita já que poucos a alcançam, porém de algo mais próximo possível do que falantes nativos compreendem como aceitável.

Acreditamos que atividades de sistematização das estruturas gramaticais empregadas por alguns professores e ainda presentes em alguns métodos, sejam necessárias até certo ponto para que a forma na conjugação verbal seja automatizada. 
Contudo temos consciência de que tais atividades são muito pouco eficazes quando se trata de escolhas adequadas, de carga cultural, de expressar emoções, de trazer à tona as outras dimensões do indivíduo.

Lançamos mão mais uma vez da palavra 'contextualização' para que os usos fiquem mais claros para o aprendiz de português língua estrangeira; da troca de papéis aluno/professor ${ }^{52}$ para que esse aluno sinta-se contribuindo em seu aprendizado ao expressar sua cultura na língua-alvo; da relevância do que é ensinado por meio de situações cotidianas ao aluno e de comunicação propositada nos livros didáticos; dos pequenos desafios para que o input compreensível de Krashen (1981, apud GERMAIN, 1996) traga motivação para ir em frente; das situações-problema para que esse aluno possa aprender a nova língua em contextos o mais próximos possível do 'mundo real'; da aprendizagem inconsciente alcançada por essas situações-problema; da aquisição pela interação social mesmo que somente dentro da sala de aula; da variedade de temas e da natureza das atividades para que um maior número de tipos cognitivos seja alcançado; do uso de materiais autênticos para atingir as dimensões histórica, ética, social, cultural, poética, corporal e subjetiva do aluno; do sentimento de pertencimento ${ }^{53}$ - conceito próximo ao da troca de papéis em sala de aula; da adequação do livro didático ao público-alvo respeitando suas expectativas de acordo com faixa etária e interesses; da ampliação vocabular e esclarecimento de aspectos lingüísticos relevantes (a própria conjugação verbal é um deles).

Enfim, lançamos mão desses conceitos ligados ao paradigma complexo e teorias afins para vislumbrarmos uma espécie de livro didático mais abrangente e que leve em consideração muitas das características do indivíduo complexo de que falamos acima quando descrevemos o nosso aluno/aprendiz.

\footnotetext{
${ }^{52}$ Como afirma Almeida Filho, "está superada a visão do professor como emissor e do aluno como receptor numa relação opressiva de cima para baixo. Os papéis (...) precisam ser intercambiados numa relação interativa de comunicação de fato" (ALMEIDA FILHO, 2002, p.15). Ou seja, o aluno precisa sentir-se motivado a trazer para a aula elementos de sua cultura, sua opinião sobre o mundo que o cerca, suas outras nuances como sujeito e expressar tudo isso na língua-alvo para contribuir efetivamente em seu aprendizado.

${ }^{53}$ Segundo Santos (2003), a noção de pertencimento do sujeito vem enfraquecendo em nosso mundo moderno, deixando no ser humano o sentimento de orfandade, desamparo e incapacidade ante uma sociedade em ritmo acelerado de mutação. A herança cultural viria superar esse sentimento de nãopertencimento. Acreditamos, por outro lado, que ao 'desestrangeirizar' o português, o aluno também passe a 'desestrangeirizar' os aspectos culturais que acompanham essa língua, muitas vezes tomandoos para si, o que traria também o sentimento de pertencimento, especialmente em situações endolíngües.
} 
Por seguir vários desses 'quesitos', escolhemos a série New Interchange como um recurso a mais para sugestões de melhorias em nosso corpus. Além disso, tal série respeita diversos princípios do paradigma complexo, especialmente o da recursividade, já que introduz novos inputs (sempre dentro da teoria do input compreensível) e os traz à tona em capítulos posteriores em novos contextos, respeitando o movimento em espiral que, segundo o paradigma complexo, o conhecimento percorre para se construir e reconstruir.

Além disso, todos os quatro livros da série seguem um formato definido vocabulário, diálogos, rápido enfoque em algum ponto gramatical, textos e atividades interativas - o que traz uma certa segurança ao aprendiz, já que este reconhece nesse formato definido os passos a serem dados para assimilar os novos inputs. É o que Morin, 1996, afirma sobre a aquisição do conhecimento que precisa do certo, do estável, do repetitivo e do predizível para poder assimilar e ordenar o aparente caos em que as informações (a nova língua) se apresentam.

Quanto à introdução de 'ser' e 'ter' nos quatro livros didáticos de português língua estrangeira, a obra que pensamos mais se aproximar de nossa base teórica é $O$ Avenida Brasil 1 e 2, já que responde a inúmeros dos quesitos levantados no capítulo 5.

Tal LD, porém, falha principalmente ao considerar pouco a troca de papéis aluno/professor e a distância entre a língua materna do aluno e a língua-alvo: a obra se diz voltada para todas as nacionalidades, mas, a nosso ver, introduz muitas informações ao mesmo tempo, situação ideal talvez para hispano-falantes, para os quais o passo a passo de livros tradicionais precisa ser evitado (de acordo com ALMEIDA FILHO, 2001).

Além disso, a aquisição por meio de interação social não é tão incentivada, possui visual pouco atraente (na concepção de TOMLINSON, 2001), além de não trabalhar muito a aproximação de culturas (conseguida pela troca de papéis aluno/professor) e, conseqüentemente, o sentimento de pertencimento do aluno.

Por outro lado, contextualiza bem as estruturas ensinadas, usa de situações relevantes para o aluno, oferece atividades mais indutivas do que dedutivas, oferece desafios, variedade, material autêntico, além de se adequar ao seu público-alvo (jovens e adultos) pela escolha de seus temas. 
Em seguida, viria o Bem-Vindo! de acordo com nossa análise de como esse LD introduz 'ser' e 'ter'. Assim como no Avenida Brasil 1 e 2, encontramos problemas nesse LD especialmente quanto ao público-alvo a que se diz destinar - estrangeiros de todas as nacionalidades, jovens e adultos, já que quanto à idade do público-alvo, nada desabona a obra, mas, quanto a sua abrangência de nacionalidades, o Bem-Vindo! peca no quesito 'pequenos desafios', porque introduz demasiadas informações de uma só vez em um mesmo capítulo, o que, a nosso ver, dificulta o uso do LD por falantes de línguas como o inglês, o alemão e orientais.

Além disso, deixa a desejar quanto ao quesito troca de papéis aluno/professor: são poucas as atividades que se dedicam a isso, nas quais o aluno teria a oportunidade de trazer um pouco de sua cultura para a sala de aula, contribuindo assim mais efetivamente para o seu aprendizado.

Nos demais quesitos, a obra se mostra bastante satisfatória, especialmente no de contextualização, atividades mais indutivas que dedutivas e a aquisição por meio da interação social. São muitas as atividades que solicitam do aluno a busca de soluções de situações-problema com o objetivo implícito de treinar os verbos em foco nas unidades, seja em duplas, seja em grupo. Além disso, são inúmeros os textos que contextualizam as estruturas a serem adquiridas.

Por outro lado, a obra deixa a desejar no quesito 'visual atraente' já que, apesar das bastantes cores utilizadas, oferece páginas muito poluídas tanto por excesso dessas cores quanto por excesso de textos de temas diferentes e sobre estruturas gramaticais diferentes em uma mesma página. Especialmente pelo excesso de informação (entenda-se input), e apesar de oferecer livros de exercícios voltados a falantes de outras línguas que não o espanhol, acreditamos que essa obra sirva muito mais ao público hispano-falante do que aos demais públicos a que ela se diz destinar.

O Falar...Ler...Escrever... deixa a desejar porque responde bem menos aos quesitos de nossa base teórica em sua introdução de 'ser' e 'ter', especialmente se comparada às duas obras citadas acima.

Seus pontos positivos são a relevância do que é ensinado, já que propõe situações do cotidiano do aluno; pequenos desafios, mesmo que de forma um tanto problemática em suas unidades iniciais, quando introduz diversos verbos irregulares ao mesmo tempo (incluídos aí 'ser' ao mesmo tempo que 'estar'); variedade, já que utiliza 
exercícios estruturais, textos sobre temas diversos e algumas situações-problema a serem resolvidas pelo aluno, porém sem a ajuda de pares.

De nossa experiência de uso dessa obra, destacamos que ela é excelente desde que complementada com outros materiais avulsos que abordem temas voltados às demais nuances do aluno (histórica, ética, estética, entre outras), já que segui-la linearmente demonstrou ser desmotivador para os alunos, especialmente para hispanofalantes.

E por fim, a obra que responde menos aos quesitos de nossa base teórica é o Fala Brasil. Esse LD não oferece material autêntico em praticamente nenhum momento que introduz e sedimenta 'ser' e 'ter', nem oportunidades de troca de papel entre aluno e professor. Além disso, as atividades são geralmente mais dedutivas que indutivas, com poucas situações propostas para que a aprendizagem inconsciente ocorra.

Quanto à distância entre a língua-alvo e a língua materna do aluno, destacamos a tentativa dos autores do Fala Brasil de pelo menos aproximar o português de duas línguas modernas - o inglês e o francês, traduzindo o título de cada atividade na parte inicial da obra para essas línguas.

Seus pontos fortes ficam nos quesitos ampliação vocabular e aspectos lingüísticos, pequenos desafios adequados ao nível do aluno, além de geralmente contextualizar as estruturas ensinadas.

Por outro lado, o visual da obra é bem pobre, com duas cores somente - o azul e o preto, além de páginas poluídas por mais de um tema ao mesmo tempo. A cultura do aluno geralmente não é considerada, nem tampouco a troca de papéis aluno/professor.

Entendemos que, de acordo com nossa análise, essas quatro obras poderiam ser utilizadas com turmas de alunos de português para estrangeiros desde que devidamente complementadas com material extra, seja para compensar a falta de variedade, seja para compensar a falta de visual atraente, ou mesmo para compensar um pouco a desconsideração parcial ou muitas vezes quase total das outras dimensões do aluno e dos vários tipos cognitivos.

Como nos lembra Ferreira (1992), o LD deve ser encarado como um instrumento, não o único, de ensino da língua. Assim, e pela nossa própria experiência no magistério de línguas estrangeiras, devemos ter em mente que o LD não pode e não deve ser usado como material exclusivo de qualquer tipo de aluno ou de turma. Mas, 
para nos mantermos fiéis à base teórica do presente trabalho, acreditamos que quanto mais cada LD analisado em nosso corpus responder aos quesitos dessa mesma base teórica, menor a quantidade necessária de material extra e de esforços por parte do professor e da instituição para a qual ele trabalha, para complementar o método para um aprendizado mais efetivo. A ordem reversa aqui é válida, ou seja, quanto menor o número de quesitos atendidos pela obra, maiores deverão ser os esforços dos profissionais envolvidos em um curso de português língua estrangeira para compensar essas limitações e buscar resultados mais favoráveis e menos frustrantes para o aluno. 


\section{Fontes}

COUDRY, Pierre \& FONTÃO, Elizabeth Fala Brasil - Português para Estrangeiros. Campinas, SP: Pontes, $10^{\mathrm{a}}$. ed., 1997.

LIMA, Emma Eberlein O.F. et al Avenida Brasil 1 - curso básico de português para estrangeiros. São Paulo: EPU, 1991.

estrangeiros. São Paulo: EPU, $2^{a}$. ed., 1998.

et al Avenida Brasil 2 - curso básico de português para

\& IUNES, Samira A. Falar... Ler... Escrever... Português, um curso para estrangeiros. São Paulo: EPU, 1999.

PONCE, Maria Harumi Otuki et al Bem-Vindo! A língua portuguesa no mundo da comunicação. São Paulo: SBS, $5^{a}$. ed., 2003.

RICHARDS, Jack C. New Interchange Intro - English for International Communication. New York: Cambridge, $7^{\text {th }}$ edition, 2001.

New Interchange 1 - English for International Communication. New York: Cambridge, $25^{\text {th }}$ edition, 2003.

New Interchange 2 - English for International

Communication. New York: Cambridge, $19^{\text {th }}$ edition, 2002.

New Interchange 3 - English for International

Communication. New York: Cambridge, 14 ${ }^{\text {th }}$ edition, 2004. 


\section{Referências Bibliográficas}

AlmeIDA FILHO, José Carlos Paes Uma metodologia específica para o ensino de línguas próximas?. In Almeida Filho, J.C. (org.) Português para estrangeiros interface com o espanhol. Campinas, SP: Pontes, 2001. Pág. $13-22$.

Almeida Filho, José Carlos Paes de Dimensões Comunicativas no Ensino de Línguas. Campinas, SP: Pontes, 2002.

BEARE, Kenneth English as second language. Disponível no site http://esl.about.com/od/grammarstructures/a/a auxpres.htm, s/d. Acesso em: 5 fev. 2006.

BRITTO, Luiz Percival Leme $A$ sombra do caos: ensino de língua $X$ tradição gramatical. Campinas, SP: Mercado de Letras, 1997.

CAmARgo, Thaís Nicoleti de Resumão de Português sobre a voz passiva analítica disponível no site http://www1.folha.uol.com.br/folha/educacao/ult305u6124.shtml, 2001. Acesso em: 10 dez. 2005.

CostA, Sônia Bastos Borba $\mathbf{O}$ aspecto em Português. São Paulo: Contexto, 2002.

CunHA, Celso Gramática do Português Contemporâneo. Rio de Janeiro: Padrão, $1983-10^{\mathrm{a}}$. ed.

Delgado, Evaldo Inácio Pilares do Interacionismo: Piaget, Vygotsky, Wallon e Ferreiro. São Paulo: Érica, 2003.

DEMO, Pedro Complexidade e aprendizagem: a dinâmica não linear do conhecimento. São Paulo: Atlas, 2002.

FERREIRA, Itacira Araújo O ensino de português para estrangeiros nos CEBs: do livro didático à sala de aula. In Almeida Filho, J.C. P. de \& Lombello, L.C. (org.) Identidade e Caminhos no Ensino de Português para Estrangeiros. Campinas, SP: UNICAMP, 1992. Pág. $59-76$.

FRANZONI, Patrícia Hilda Nos bastidores da comunicação autêntica - uma reflexão em Lingüística Aplicada. Campinas, SP: UNICAMP, 1992.

FREIRE, Paulo Pedagogia da Autonomia - saberes necessários à prática educativa. São Paulo: Paz e Terra, 1996.

Galloway, Ann Communicative Language Teaching: An Introduction And Sample Activities., Washington DC: CAL Center for Applied Linguistics, 1993 - disponível no site www.cal.org Acesso em: 5 maio 2005. 
GARCIA, Afrânio da Silva Verbos Designativos do Português. Disponível no site http://www. filologia.org.br/soletras/1/12.htm, novembro de 2001. Acesso em: $11 \mathrm{dez}$. 2005.

Germain, Claude As interações sociais em aulas de uma segunda língua ou idioma estrangeiro. In Garnier, C. et al Após Vygotsky e Piaget - Perspectivas Social e Construtivista Escolas Russa e Ociental. Porto Alegre, RS: Artes Médicas, 1996. Pág. $92-100$.

GLEICK, James Caos - a criação de uma nova ciência. Rio de Janeiro: Elsevier, 1989.

GoMES, Nataniel dos Santos Verbos leves - observações sobre o português do Brasil. Disponível no site http://www.filologia.org.br/soletras/8sup/7.htm, s/d. Acesso em: 3 dez. 2005.

HOPPER, Paul J. \& TRAugotT, Elizabeth Closs Some further issues. In Grammaticalization. Cambridge, UK: Cambridge University Press, 1993. Pág. 204 221.

ILARI, Rodolfo A expressão do tempo em português. São Paulo: Contexto, coleção Repensando a Língua Portuguesa , 2001.

JúDICE, Norimar Quem conta um conto? A sala de aula de PLE como ponto de encontro entre culturas. In Almeida Filho, J.C.P. de Português para Estrangeiros Interface com o Espanhol. Campinas, SP: Pontes, 2001. Pág. 65 - 76.

KARTChner, Paul La teoría del caos y el lenguaje. Arizona, $10^{\circ}$. Simposio anual, s/d. Pág. $89-96$.

KLEIMAN, Angela Texto \& Leitor - aspectos cognitivos da leitura. Campinas, SP: Pontes, 2002.

KRASHEN, Stephen D. et al (editors) Child-Adult Differences in Second Language Acquisition. Rowley, Massachusetts: Newbury House Pub., 1982.

KUNZENDORFF, Júlia Cristina Considerações quanto ao ensino de Português para estrangeiros adultos. In Almeida Filho, J.C. \& Lombello, L.C. 0 ensino de Português para estrangeiros - pressupostos para o planejamento de cursos e elaboração de materiais Campinas, SP: Fontes, 1997. Pág. $19-39$.

LEIRIA, Isabel Aquisição do Aspecto Verbal por Falantes Não Nativos de Português Europeu: a exemplo dos Pretéritos Perfeito e Imperfeito. In Revista Internacional de Língua Portuguesa Lisboa: Associação das Universidades de Língua Portuguesa, julho de 1994. Pág. $74-112$. 
MARTINS, João Carlos Vygotsky e o papel das interações sociais na sala de aula: reconhecer e desvendar o mundo. Tese de doutorado disponível no site http://www.crmariocovas.sp.gov/pdf/ideias $28 \mathrm{Plll}-\mathrm{H} 2$ c.pdf s/d. Acesso em: 3 mar. 2005.

Marxists Mind and society de Vygotsky - 1930, Harvard University Press, disponível no site http://www.marxists.org/archive/vygotsky/works s/d. Acesso em: 22 fev. 2005.

MENEZES, Vera Modelo fractal de aquisição de línguas. Disponível no site http://www.veramenezes.com/modelo.htm, s/d. Acesso em: 2 ago. 2004.

Michaelis: Moderno Dicionário Da Língua Portuguesa. São Paulo, SP: Companhia Melhoramentos, 1998.

MOITA LOPES, Luiz Paulo Adaptando a validade teórica do conceito de interlíngua. In Moita Lopes, LP Oficina de Lingüística Aplicada - a natureza social e educacional dos processos de ensino/aprendizagem de línguas. Campinas, SP: Mercado de Letras, 1996. Pág. $113-124$.

MoRIN, Edgar Pensamento e Linguagem. In Morin, Edgar $\mathbf{O}$ Método III - 0 conhecimento do conhecimento Portugal: Publicações Europa-América Ltda., 1996. Pág. $114-119$.

Complexidade e ética da solidariedade. In CASTRO, G. et al Ensaios de complexidade. Porto Alegre: Sulina, 1997. Pág. 15 - 24.

Problemas de uma epistemologia complexa. In Morin, Edgar (org.) 0 problema epistemológico da complexidade. Portugal: Europa-América, s/d. Pág. 13 -34 .

Peirópolis, 2000.

\& LE MoIGNE, Jean-Louis A inteligência da complexidade. São Paulo:

Da Linguagem. In Morin, Edgar O Método IV - As idéias. Porto Alegre: Sulina, 2002a. Pág. $197-210$.

A propósito dos sete saberes. In Almeida, M.C. \& Carvalho, E.A. Educação e Complexidade: os sete saberes e outros ensaios. São Paulo: Cortez, 2002b. Pág. 75 - 102.

Educar na Era Planetária - O pensamento complexo como método de aprendizagem pelo erro e incerteza humana. Brasília: Cortez, 2003.

NeVES, Maria Helena de Moura A Gramática Funcional. São Paulo: Martins Fontes, 1997. 
Contexto, 2004.

Que gramática estudar na escola?. São Paulo:

ORLANDI, Eni P. Análise de Discurso: princípios e procedimentos. Campinas, SP: Pontes, $4^{\mathrm{a}}$. edição, 2002.

PUREN, Christian L'Evolution Historique des Approches en Didactique des LanguesCultures, ou comment faire l'Unite des "Unites Didactiques" - Congrès annuel de l'Association pour la Diffusion de l'Allemand em France (ADEAF), École Supériuere de Commerce de Clermont-Ferrand, 2-3 novembre 2004. Conférence du 2 novembre 2004. Disponível no site http://www.tesol-france.org/articles/Colloque05/Puren05.pdf . Acesso em: 28 nov. 2006.

Programme de Coopération Européenne, s/d a. Disponível no site http://www.payisdeloire.iufm.fr/IMG/pdf/didactique espagnol2.pdf . Acesso em: 28 nov. 2006.

Le Cadre européen commun de Référence et la reflexión méthologique en Didactique des Langues-Cultures: un chantier à reprendre, s/d b. Disponível no site http://perso.orange.fr/fle-sitographie/GERFLINT/Baltique3/Puren.pdf . Acesso em: 28 nov. 2006.

REVUZ, Christine A língua estrangeira entre o desejo de um outro lugar e o risco do exílio. In SIGNORINI, Inês Língua(gem) e Identidade: elementos para uma discussão no campo aplicado. Campinas, SP: Mercado de Letras; São Paulo: FAPESP, 1998. Pág. $213-230$.

RONG, F.U. L'éclectisme en milieu institutionnel chinois de français: une option spontanée et naturelle, obligée et obligatoire, mais risqué à certains égards. Disponível no site http://www.fl.fju.ed.tw/lang teaching/papers/fren 3.pdf , Université des Langues étrangères de Beijing, s/d. Acesso em: 27 nov. 2006.

SANTos, Akiko Didática sob a ótica do Pensamento Complexo. Porto Alegre: Sulina, 2003.

Sonoo, Rosa Tokiko A voz passiva em japonês - Ukemi. Disponível no site http://www.sonoo.com.br/Vozpassiva.html, s/d. Acesso em: 13 set. 2005.

TAN, Charlene H.P. An evaluation of the Communicative Approach for the Teaching of the General Paper in Singapore. In Journal of Language and Learning. - volume 2 Number 1, 2004 - Nanyang Technological University, Singapore http://www.shakespeare.uk.net/journal/jllearn/2 2/tan2 2.html . Acesso em: 15 mar. 2005.

TOMLINSON, Brian (Editor) Materials Development in Language Teaching. Cambridge: Cambridge University Press, 2001. 
The Pennsylvannia State University. http://www.personal.psu.edu Acesso em: 25 nov. 2006.

Wikipedia. Disponível no site www.wikipedia.com.br . Acesso em: 1/5/2007.

VAN DE WIEL, Franciscus W. Os pretéritos perfeito e imperfeito no uso não nativo do português. In Almeida Filho, J.C. de (Org.) Português para estrangeiros interface com o espanhol. Campinas, SP: Pontes, 2001.Pág. 59 - 64.

VAN PASSEL, Frans Os problemas dos adultos. In van Passel, F. Ensino de línguas para adultos. São Paulo: Pioneira: Ed. Universidade de São Paulo, 1983. Pág. 27 - 38;

VYGOTSKY, Lev Seminovich Interação entre aprendizado e desenvolvimento. In Vygotsky, LS A formação social da mente: o desenvolvimento dos processos psicológicos superiores. São Paulo: Martins Fontes, 1991. Pág. 89 - 103.

VYGOTSKY, L.S. Pensamento e Palavra. In Vygotsky, LS Pensamento e Linguagem. São Paulo: Martins Fontes, 1998. Pág. 149 - 190. 